CUADERNOS DE ESTUDIOS GALLEGOS, LXIV Núm. 130 (enero-diciembre 2017), págs. 229-312

ISSN: $0210-847 \mathrm{X}$

DOI: $10.3989 /$ ceg.2017.130.08

\title{
DESPUÉS DE LEPANTO: CORSARIOS TURCOS Y BERBERISCOS EN LAS COSTAS DE GALICIA EN EL SIGLO XVII
}

\author{
José Martínez CRESPo \\ Universidad de Santiago de Compostela \\ ORCID iD: http://orcid.org/0000-0002-2933-2418
}

Copyright: (C) 2017 CSIC. Este es un artículo de acceso abierto distribuido bajo los términos de una licencia de uso y distribución Creative Commons Attribution (CC-by) España 3.0.

Cómo citar/Citation: José MARTínEZ CRESPO, "Después de Lepanto: corsarios turcos y berberiscos en las costas de Galicia en el siglo XVII", Cuadernos de Estudios Gallegos, 64, núm. 130 (2017), págs. 229-312, DOI: http://dx.doi.org/10.3989/ceg.2017.130.08 


\section{DESPUÉS DE LEPANTO: CORSARIOS TURCOS Y BERBERISCOS EN LAS COSTAS DE GALICIA EN EL SIGLO XVII}

RESUMEN

Después de la victoria sobre los moriscos y del éxito de la batalla de Lepanto, cristianos y musulmanes continuaron enfrentándose en el mar. En el siglo XVII, los corsarios turco-berberiscos, entre los que se incluían moriscos expulsados de España y un buen número de renegados cristianos, lograron extender sus actividades corsarias hacia el océano Atlántico gracias a la adaptación del modelo de barcos construidos y armados a la europea. En 1617 los corsarios turco-berberiscos iniciaron sus ataques a Galicia con el asalto a la ría de Vigo y el saqueo y quema de Cangas, amenazando a lo largo de todo el siglo de forma constante al comercio marítimo y a las poblaciones costeras, cautivando a sus naturales y perjudicando las faenas pesqueras. Hacia 1621 surgió un corsarismo gallego especialmente dirigido contra ellos y contra los holandeses, iniciándose la construcción de una "Escuadra de Galicia", que no pudo cumplir sus objetivos. Por otra parte, muchos cristianos cautivos se convirtieron al Islam con la esperanza de un mejor trato y fortuna. Muchos de estos renegados tuvieron la oportunidad de enrolarse como corsarios y de poder huir y volver a la cristiandad, pero, por su condición de apostatas, antes de conseguir su plena reincorporación a la sociedad cristiana debían presentarse ante los tribunales de la Inquisición para ser absueltos. En el siglo XVIII, el corso turco-berberisco inició su declive, quedando anuladas sus bases y actividades predatorias en el siglo XIX con el establecimiento de protectorados europeos en el norte de África y la retirada del Imperio Turco del Mediterráneo occidental.

Palabras CLAVE: Lepanto, corso turco-berberisco, siglo XVII, Galicia, cautivos y renegados.

\section{DESPOIS DE LEPANTO: CORSARIOS TURCOS E BERBERISCOS NAS COSTAS DE GALICIA NO SÉCULO XVII}

RESUMO

Despois da vitoria sobre os mouriscos e do éxito da batalla de Lepanto, cristiáns e musulmáns continuaron enfrontándose no mar. No século XVII, os corsarios turco-berberiscos, entre os que se incluían mouriscos expulsados de España e un bo número de renegados cristiáns, lograron estender a súas actividades corsarias cara o océano Atlántico grazas á adaptación do modelo de barcos construídos e armados á europea. En 1617 os corsarios turco-berberiscos iniciaron os seus ataques a Galicia con o asalto á ría de Vigo e o saqueo e queima de Cangas, ameazando ao longo de todo o século de forma constante o comercio marítimo e as poboacións costeiras, cativando aos naturais e prexudicando as faenas da pesca Cara o ano 1621 xurdiu un corsarismo galego especialmente dirixido contra eles e os holandeses, iniciándose a construción dunha "Escuadra de Galicia", que non puido cumprir os seus obxectivos. Por outra banda, moitos cristiáns cativados convertéronse ao Islam coa esperanza dun mellor trato e fortuna. Moitos destes renegados tiveron a oportunidade de enrolarse como corsarios e de poder fuxir e volver á cristiandade, pero, pola súa condición de apostatas, antes de conseguir a súa plena reincorporación á sociedade cristiá debían presentarse ante os tribunais da Inquisición para ser absoltos. No século XVIII, o corso turco-berberisco iniciou o seu declive, quedando anuladas as súas bases e actividades predatorias no século XIX con o establecemento de protectorados europeos no norte de África e a retirada do Imperio Turco do Mediterráneo occidental.

PALABRAS CLAVE: Lepanto, corso turco-berberisco, século XVII, Galicia, cativos e renegados.

\section{AFTER LEPANTO: TURKISH AND BERBER CORSAIRS ON THE COAST OF GALICIA IN THE $17^{\text {th }}$ CENTURY}

ABSTRACT

After the victory over the Moors and the success at the Battle of Lepanto, Christians and Muslims continued fighting each other at sea. In the seventeenth century, Turkish-Berber pirates, including Moors expelled from Spain and a large number of Christian renegades, succeeded in extending their corsair activities to the Atlantic Ocean by adapting the European way of building and arming ships. In 1617 the Turkish-Berber pirates started their attacks on Galicia with the assault on the Vigo estuary and the looting and burning of Cangas, and throughout the century they threatened maritime trade and coastal villages, capturing their inhabitants and damaging the fishing operations. About 1621 a Galician privateering arose especially directed against them and against the Dutch, with the construction of a "Squad of Galicia", which could not fulfill its objectives. On the other hand, many captive Christians converted to Islam in the hope of a better treatment and fortune. Many of these renegades had the opportunity of joining as corsairs and of being able to flee and return to Christianity, but, as they were apostates, before getting their full reincorporation into Christian society they had to appear before the Inquisition tribunals to be acquitted. In the eighteenth century, Turkish-Berber corsairs began its decline, as their predatory bases and activities were annulled in the $19^{\text {th }}$ century with the establishment of European protectorates in North Africa and the withdrawal of the Turkish Empire from the western Mediterranean. KEY WORDS: Lepanto, Turkish-Berber corso, $17^{\text {th }}$ century, Galicia, captives and renegades. 
Recibido/Received: 13/03/2017

Aceptado/Accepted: 21/04/2017

\section{GALICIA, UNA REGión ALEJADA DEL MUNDO MUSULMÁN EN EL SIGLO XVI}

unque el renombrado historiador gallego Manuel Murguía escribió que
el estandarte de Galicia había ondeado como tal en uno de los buques
que asistieron al combate naval de Lepanto el 7 de octubre de $1571^{1}$, y la catedral de Santiago recibió en ofrenda el gallardete que ondeaba en la nao capitana de don Juan de Austria durante la célebre batalla ${ }^{2}$, los contactos del Reino de Galicia con los musulmanes a lo largo del siglo XVI fueron muy limitados. La posición periférica de la región gallega en la zona Atlántica del Noroeste de España y la casi permanente coyuntura bélica de la Corona española hicieron que durante este siglo las agresiones navales en sus costas procedieran siempre de las potencias navales europeas, especialmente de Francia e Inglaterra y, en menor medida, Holanda.

Episódica fue igualmente la relación que Galicia mantuvo con la población morisca que aún vivía en la Península y cuya difícil situación religiosa derivaría

\footnotetext{
1 Murguía decía que la Escuadra de Galicia, fue hija de la diaria y creciente necesidad que tenía el país gallego de defender de toda clase de piratería la dilatada costa que le ciñe, y aun la de servir a la monarquía, pues sólo así se explica que el estandarte de Galicia ondease como tal en uno de los buques que asistieron al memorable combate naval de Lepanto. Manuel [Martínez] Murguía, España. Sus monumentos y artes, su naturaleza e historia. Galicia, Barcelona, Establecimiento Tipográfico-Editorial de Daniel Cortizo y C. 1888, pág. 315. Sin embargo, Fernández Villamil ya se quejaba en 1953 de que Murguía no citaba la fuente de origen de esta noticia: que no puedo rastrear, como sería mi deseo, en las relaciones de barcos que asistieron a la batalla y da Fernández Villamil en Armada Española, II, 177 y ss. tomándolas del Archivo de Simancas, Estado, legajo 1.134. En la batalla se alineaba una galera llamada Santiago, cuyo capitán no se cita, y era una de las seis que enviaba en vanguardia la Orden de San Juan, al mando de Pedro Giustiniano. Otro Santiago, de la Orden de Malta, iba al cuerno siniestro de la Real. Enrique FERNÁNDEZ Villamil, La Escuadra de Galicia, Pontevedra, El Museo de Pontevedra; CSIC, 1952, pág. 20 y nota 39. Sí sabemos que quien acompañaba a don Juan de Austria en esta lid como su secretario era el gallego Andrés de Prada y Gómez de Santalla, nacido en Outarelo (O Barco de Valdeorras) entre 1540 y 1550. Véase Isidro García TATo, La casa de Outarelo de Valdeorras. Formación y desarrollo de su patrimonio (siglos XIV-XX), Santiago de Compostela, Graficas Loureiro, 2001 (Colección Trevinca), págs. 23-27.

2 El gallardete de Lepanto, de 17 metros y medio de largo, pintado al temple y ornamentado con las armas de las naciones que componían la Santa Liga y las de don Juan de Austria, un Cristo crucificado acompañado por la Virgen y San Juan, y la figura del Apóstol Santiago, se exponía todos los años colgado de la nave central de la catedral en la Novena del Apóstol.
} 
en un grave conflicto interno. La lucha iniciada por los moriscos en 1568 proclamando como su rey a Hernando de Córdoba y Valor con el nombre de Aben Humeya en la localidad de Béznar (Valle de Lecrín en Granada), dio lugar a dos años de feroz lucha que terminaría con su sometimiento por don Juan de Austria; aunque sólo el asesinato de Aben Boo, sucesor de Aben Humeya, el 15 de marzo de 1571, marcaría el final de la tenaz resistencia morisca ${ }^{3}$. Los nobles gallegos, como los del resto de la Corona, estuvieron obligados a participar en esta guerra, ordenando Felipe II en 1570 que los caballeros e hijosdalgos del Reino de Galicia se preparasen para acudir, a serbir a la parte donde les fuere hordenado ${ }^{4}$.

El antiguo recelo hacia los moriscos supuso su expulsión del Reino de Granada y su reparto por los territorios del resto de la Península. En el segundo de estos repartos, que se hizo en noviembre de 1570, se organizaron dos grupos: los moriscos de Granada y su vega, Valle de Lecrín, Sierra de Bentomiz, la Ajarquía, Hoya de Málaga, Marbella y la Serranía de Ronda marcharían a Córdoba para ser distribuidos en Extremadura y Galicia; los restantes lo fueron en La Mancha, Toledo y Castilla la Vieja. Sin embargo, este plan no se efectuaría en la forma prevista, ya que toda la zona cantábrica, País Vasco, Santander, Asturias y Galicia no llegaron a recibir moriscos, seguramente a causa de su lejanía respecto de los puntos de origen y de su acceso al mar; los más cercanos se distribuyeron por tierras de León y Zamora. Por entonces se fraguaba un nuevo plan de reparto, que pretendía fijarlos lejos de las costas - para evitar la huida y el contacto con turcos y berberiscos- y en lugares pequeños, de los que se les prohibía desplazarse para evitar que se concentrase un gran número en las ciudades ${ }^{5}$.

Así pues, a Galicia no llegaron moriscos repartidos más que excepcionalmente, y ello pese a que alguna provincia, Betanzos, mostró interés por recibirlos. Se sabe que en 1572, fueron llevados a ella el padre y el hermano de Hernando de Valor, que estaban prisioneros desde 1569. Ambos consiguieron escapar con la ayuda de un esclavo morisco en 1575, pero fueron detenidos y conducidos al monasterio de Montederramo (Orense) el primero, y al monasterio de Samos (Lugo) el segundo. Este último, de nombre Francisco, pasó en 1579 al monasterio benedictino de San Vicente do Pino, y en 1583 u 84 quiso ingresar en la Orden, lo que provocó gran recelo en el abad, poniéndose de manifiesto la inquietud que los moriscos seguían causando.

\footnotetext{
3 María del Carmen Gonzélez Muñoz, Galicia en 1571: Población y economía, Sada-Coruña, Ediciós do Castro, 1982, pág. 19.

4 Colección de documentos históricos de la Real Academia Gallega, vol. I, Coruña, Litografía e Imp. Roel, 1915, págs. 176-180.

5 M. C. GonZÁlez Muñoz, Galicia en $1571 \ldots$, págs. 20-21 y nota 14.
} 
En 1610, cuando se produjo la definitiva expulsión de los musulmanes españoles, un barco francés que transportaba a Tánger 150 moriscos procedentes de Hornachos y de Llerena (Extremadura), en vez de dirigirse allí, conociendo quizás el mal recibimiento dado a otros emigrantes forzosos, arribó en marzo a la ría de Arousa en Galicia. Cuando habían muerto ya unos diez moriscos en el transcurso del viaje, los restantes fueron desembarcados por no haber pagado los gastos.

Como puede observarse, los contactos de los moriscos con Galicia fueron episódicos, de manera que nunca se establecieron en la región. Por eso en 1595, cuando ya estaban asentados en otras partes, desde círculos inquisitoriales se informaba de que, No hay morisco alguno avecindado en este Reino de Galicia ${ }^{6}$.

\section{Después de Lepanto. El salto al Atlántico del corso turco-Berberisco}

A pesar de la victoria sobre los moriscos y del éxito incuestionable que para las armas cristianas supuso la batalla de Lepanto en 1571, la situación en el Mediterráneo no quedó lo suficientemente resuelta como para impedir que cristianos y musulmanes siguieran enfrentándose. Aunque la poderosa Armada turca quedó destrozada y en los dos años siguientes los otomanos se vieron obligados a restringir sus operaciones navales a un papel netamente defensivo, la flota musulmana se rehízo pronto del desastre e incluso pudo recuperar algunas plazas.

No obstante la dificultad de ambos contendientes para seguir manteniendo la lucha a gran nivel en el mar, y la disposición que mostraban para alcanzar la paz, a la gran guerra marítima que tuvo su punto álgido en Lepanto sucedió un enfrentamiento que se prolongaría desde 1575 hasta las postrimerías del siglo XVII -y aún después- a través de una guerra a más pequeña escala ${ }^{7}$. Se abría así un período en el que los corsarios y piratas norteafricanos reanudarían

muy pronto y con más fuerza si cabe sus actividades predatorias, al conseguir ampliar decididamente su radio de acción en las primeras décadas de la siguiente centuria.

Si bien los españoles solían llamar piratas a los turcos y berberiscos que asolaban sus costas, esta denominación no era del todo correcta, pues éstos solían

\footnotetext{
${ }_{6}$ Ibidem, págs. 21-22 y notas.

7 Beatriz Alonso Acero, Orán y Mazalquivir en la política norteafricana de España, 1589-1639, tesis doctoral inédita, Departamento de Historia Moderna, Facultad de Geografía e Historia, Universidad Complutense de Madrid, 1997, vol. 1, pág. 17; véase también el artículo de la misma autora, "Entre el Mediterráneo y el Atlántico: corso europeo y corso turco-berberisco en el siglo de los Felipes", en IV Centenario del ataque de Van der Does a las Palmas de Gran Canaria (1999). Coloquio internacional "Canarias y el Atlántico. 1580-1648”, Las Palmas de Gran Canaria, Ediciones del Cabildo de Gran Canaria, 2001, págs. 169-170.
} 
depender de las ciudades-repúblicas del norte de África, como Argel o Salé ${ }^{8}$ En líneas generales, los corsarios actuaban bajo la supervisión de un Estado que, en cierta manera, se hacía responsable de sus acciones y establecía una serie de reglas y disposiciones que les obligaban a mantenerse dentro de las leyes del Derecho, al contrario que los piratas, que se gobernaban por normas particulares y no tenían necesidad de legalizar sus presas ni dependían de institución oficial alguna que limitase sus excesos ${ }^{9}$. Asimismo, también se distinguía a estos corsarios y piratas con el nombre de moros y turcos. Los primeros, más numerosos, eran los naturales del norte de África; los segundos en cambio constituían la clase dirigente de Argel y eran descendientes de los antiguos turcos allí afincados o de renegados que habían conseguido el estatus de turco ${ }^{10}$.

Desde mucho tiempo atrás, los corsarios musulmanes eran una verdadera plaga para los reinos que se asomaban al Mediterráneo, pero a comienzos del siglo XVII se produjo un cambio notable en la técnica y táctica que utilizaban. Según la teoría más extendida, con la llegada a Argel del corsario holandés Simon Danser* y gracias a los avances técnicos en que este les instruyó en torno a 1606, los corsarios argelinos iniciaron la construcción de barcos de mayor calado y alto bordo al estilo de los que desde el siglo XVI se usaban en el Atlántico. Según parece, un inglés llamado John Ward o Warde, prestaría el mismo servicio a los corsarios de Túnez con la ayuda de un renegado griego, el Reis Memi.

Los astilleros de Argel, Túnez y Trípoli se convirtieron entonces en hervideros de obreros que se afanaban en el aprendizaje de las nuevas técnicas. En la primera ciudad, bajo la supervisión de Danser, se produjo la adaptación del modelo de "barcos redondos", naves de velas cuadradas, paradójicamente llamadas también "velas redondas" organizadas y armadas a la europea, que el corsario holandés les enseñaría a construir y a gobernar ${ }^{11}$.

\footnotetext{
8 Enrique Otero Lana, Los corsarios españoles durante la decadencia de los Austrias. El corso español del Atlántico peninsular en el siglo XVII (1621-1697), Madrid, Ministerio de Defensa, 1999, pág. 174, nota 42.

9 Ibidem, pág. 69.

${ }^{10}$ Maximiliano Barrio Gozalo, "Esclavos musulmanes en la España del siglo XVIII", Anales de Historia Antigua, Medieval y Moderna, vol. 49 (2015), pág. 52.

${ }^{11}$ Sobre este tema, Stanley Edward Lane-Poole, Los corsarios berberiscos, [Sevilla], Editorial Renacimiento, 2011 (Colección Isla de la Tortuga), pág. 198; Philip Henry Gosse, Historia de la piratería, [Sevilla], Editorial Renacimiento (colección Isla de la Tortuga), 2008. pág. 69; Ramiro FeıJoo, Corsarios berberiscos. El reino corsario que provocó la guerra más larga de la Historia de España, Barcelona, Belacqva de Ediciones y publicaciones, 2003, págs. 122-124 y 128; B. Alonso Acero, Orán y Mazalquivir...; vol. I, pág. 29; "Entre el Mediterráneo y el Atlántico...”, pág. 174; Cesáreo FernÁndez Duro, Armada española desde la unión de los Reinos de Castilla y Aragón, vol. III, Madrid, 1900, págs. 323 y 353; E. Otero LANA, Los corsarios españoles..., págs. 174-175 y 260.

* der Tantzer, o Zymen Danseker, llamado por los berberiscos Deli Reis, “el capitán Diablo”.
} 
¿Fueron realmente Danser y Ward los verdaderos instigadores de la revolución Atlántica en Berbería? El hecho cierto es que la navegación Atlántica arraigó en Argel y Túnez, sino a través de ellos mismos, sí a través de gentes de parecida condición, y de su mano los corsarios berberiscos lograron salir de su área tradicional $^{12}$. No sólo toda la cuenca del mediterráneo se hizo accesible a los corsarios tanto en verano como en invierno, hubiese bonanza o temporal, sino que incluso se permitieron infectar las rutas marítimas por las cuales navegaban las grandes flotas españolas ${ }^{13}$.

Las causas del cambio fueron dobles: en primer lugar, no siempre era fácil encontrar esclavos cristianos, y contratar remeros para las galeras era demasiado caro; en segundo lugar, los desembarcos en las costas mediterráneas españolas, a los que se destinaban particularmente las galeotas más pequeñas y bergantines, empezaban a verse obstaculizados por la expulsión definitiva de los últimos moriscos de Andalucía en 1610. Privados de los guías y simpatizantes que tan a menudo habían colaborado en sus exitosas incursiones y azuzados por el deseo de más botín y cautivos, los corsarios deseaban extender sus asaltos, para lo cual eran necesarios navíos más grandes y más combatientes. Un viaje largo era imposible en una galera, donde había varios cientos de remeros que alimentar y cada carga de bizcocho afectaba a la propulsión, pero los nuevos barcos de vela admitían una gran carga de provisiones y ya no necesitaban remeros cuyos brazos pudieran acusar el cansancio ${ }^{14}$.

Paralelamente a este avance tecnológico, una parte nada despreciable de los moriscos llegados al Norte de África se convirtieron en corsarios al servicio de las flotas turco-berberiscas, dando lugar a un incremento sustancial de los ataques a barcos españoles que navegaban por las aguas del Mediterráneo occidental y del Atlántico marroquí. Este auge del corso se explica, en primer lugar, por el deseo de venganza de los moriscos frente a los autores de su expulsión, y también por la necesidad de demostrar a sus hermanos de religión que su confesión nunca había dejado de ser la musulmana. El buen conocimiento que tenían de las costas españolas -levantinas y andaluzas- hizo que fueran muy bien aceptados como tripulantes en las expediciones, no sólo para abordar a las embarcaciones cristianas, sino también para asaltar el litoral que tan bien conocían, incrementándose las amenazas contra las poblaciones asentadas en los territorios ribereños de la Península ${ }^{15}$.

\footnotetext{
${ }_{12}$ R. Feijoo, Corsarios berberiscos..., pág. 125.

13 P. Gosse, Historia de la piratería..., pág. 69.

14 S. E. Lane-Poole, Los corsarios berberiscos..., págs. 198-199.

15 B. Alonso Acero, Orán y Mazalquivir...; vol. II, pág. 454; "Entre el Mediterráneo y el Atlántico...”, pág. 183.
} 
Las dotaciones corsarias musulmanas pasaron así a estar formadas por una variopinta mezcla de berberiscos, turcos, moriscos peninsulares expulsados, renegados europeos, e incluso esclavos, los cuales podían enrolarse y buscar mejores oportunidades a cambio de proporcionar a los infiltrados valiosa información ${ }^{16}$.

Argel también se erigió en este momento en el principal protector y animador por excelencia del corso morisco, impulsando su avance en connivencia con el turco-berberisco y con el holandés, inglés y francés, primero hacia el Mediterráneo occidental y luego hacia el estrecho de Gibraltar y la costa atlántica africana. Desde este último punto, el objetivo especialmente ambicionado por todos ellos era atacar a las ricas flotas de Indias. Es el caso de las naves del propio Simón Danser, que parten de Argel el 15 de agosto de 1609, con disignio de aguardar la flota de las Yndias de Castilla y procurar hazer algún buen lançe. Alertas como ésta evidenciaban la necesidad de reforzar la vigilancia del Estrecho, función encomendada a la Armada del Mar Océano, creada en 1607, la cual no siempre podía actuar con la suficiente rapidez y eficacia ${ }^{17}$.

Para tratar de cortar este avance, los españoles trataron de apoderarse de las principales plazas corsarias de la fachada Atlántica de Marruecos. En noviembre de 1610 conquistaron Larache, dejando a sus corsarios y piratas sin un puerto que les servía como base y refugio; pero simplemente se trasladaron a otro situado algunas millas más al sur, La Mamora, que también fue ocupado por una flota española al mando de Luis Fajardo en agosto de 1614. El fin de ambas operaciones no era expansionista, sino un intento por parte de la Corona de defender sus intereses comerciales y financieros y los de los habitantes de las costas andaluzas, portuguesas, gallegas, canarias y los de los españoles que vivían en el Norte de África. Sin embargo, los corsarios y piratas se desplazaron de nuevo a otros puertos situados más al sur de la costa marroquí y, además, consiguieron incrementar su número y su efectividad como resultado de la coincidencia de estas conquistas con la expulsión de los moriscos.

Salé, enclave portuario situado en la costa atlántica africana, a muy pocas millas al sur de La Mamora, pasó a desempeñar desde la segunda década del siglo XVII el papel anteriormente protagonizado por los dos puertos conquistados, sirviendo de nuevo refugio a gran número de Moriscos de Hornachos y andalusíes, otomanos de Argel y holandeses renegados. A escasas cincuenta millas de Gibraltar, Salé

\footnotetext{
$\overline{16}$ Enrique Pérez Herrero (coord.), Documentos y estudio sobre el corsarismo en Canarias (Descripción archivística, transcripción y edición facsímil), Las Palmas de Gran Canaria, Gobierno de Canarias Beginbook Ediciones, 2011, pág. 15.

17 B. Alonso Acero, Orán y Mazalquivir..., vol. II, págs. 454 y 554; "Entre el Mediterráneo y el Atlántico...”, pág. 175. Esta Armada, compuesta por tres escuadras formadas por 10 galeones cada una con base en Cádiz, tenía la misión de vigilar desde Gibraltar hasta el cabo San Vicente para escoltar y proteger las flotas de Indias a su regreso, operando entre las islas de Madeira, Azóres y Canarias.
} 
permitía al corso vigilar cuanto circulaba por las proximidades del Estrecho y acechar a los navíos procedentes de las Indias orientales y occidentales ${ }^{18}$.

Ciertamente, el Atlántico no había sido un territorio vedado a las incursiones berberiscas -frecuentes ya anteriormente en Cádiz y el Algarve portugués-, pero sí su altamar; hasta el siglo XVII la navegación corsaria en el Atlántico había estado circunscrita al cabotaje ${ }^{19}$. Existía no obstante un precedente: en 1585, el Reis Murad se atrevió a salir al Atlántico hasta perder de vista tierra, lo que ningún argelino se había atrevido a hacer hasta entonces. Tras unirse en Salé a un refuerzo de pequeños bergantines, Murad desembarco al amanecer en Lanzarote y la saqueó sin resistencia, llevándose a la familia del Gobernador y a trescientos cautivos; después tuvo la insolencia de izar la bandera de tregua y permitió a dicho Gobernador y a las principales familias subir a bordo a comprar la liberación de sus parientes ${ }^{20}$.

Pero a partir de la siguiente centuria las nuevas técnicas esfumarían las limitaciones, aportando la confianza necesaria para romper el miedo a la navegación en altura. Ahora podían amenazar las islas de Madeira, las Azores (Terceira) y las Canarias (Lanzarote sobre todo), en busca de esclavos, acechando desde ellas para cazar a los barcos rezagados o perdidos del comercio americano y recorrer las costas de Portugal y Galicia. Posteriormente, desde el primer cuarto del siglo XVII, los corsarios turco-berberiscos llegarían incluso a alcanzar las altas latitudes europeas, las costas bálticas e islandesas y las de Terranova, hasta entonces imposibles para ellos ${ }^{21}$.

El importante cambio que se estaba produciendo se constata ya en 1616. Sir Francis Cottington, embajador de Inglaterra ante la Corte española, informa ese año al Duque de Buckingham que los veleros de Argel estaban despertando la alarma general en España:

El poder y la audacia de los piratas berberiscos han alcanzado tal
altura, tanto en el Océano como en las aguas del Mediterráneo, que
no he conocido nada que haya sido de mayor pesar y preocupación
en esta Corte que las noticias diarias que se reciben al respecto.
Integran su flota completa cuarenta veleros entre doscientas y
cuatrocientas toneladas cada uno; y su nave insignia alcanza las

\footnotetext{
${ }_{18}$ B. Alonso Acero, Orán y Mazalquivir..., vol. I, págs. 38-44 y 62-63; "Entre el Mediterráneo y el Atlántico...”, págs. 177-180 y 183-184.

19 R. Feijoo, Corsarios berberiscos..., págs. 124-125.

20 S. E. Lane-Poole, Los corsarios berberiscos..., pág. 172.

${ }^{21}$ R. Feijoo, Corsarios berberiscos..., págs. 124-126; E. Otero Lana, Los corsarios españoles..., págs. $174-175$ y 260.
} 
quinientas. Se divide en dos escuadrones; el primero, compuesto por dieciocho veleros, permanece frente a Málaga, a la vista de la ciudad; el otro en los alrededores del cabo de Santa María, que se haya entre Lisboa y Sevilla...

El primer escuadrón interceptaba a los barcos que pasaban frente a Málaga, impidiendo por completo el comercio, mientras que el segundo hacía lo propio fuera del Estrecho, y la flota española era demasiado reducida, lenta y pesada para impedirlo ${ }^{22}$.

En 1617 los corsarios turco-berberiscos pasaron el estrecho con ocho navíos bien armados y se dirigieron a Madeira, donde desembarcaron ochocientos hombres. Las escenas que se siguieron fueron las habituales en tales casos: la isla asolada, sus iglesias saqueadas y ultrajadas, sus gentes esclavizadas... Doscientos hombres, mujeres y niños llegaron a Argel entre grandes salvas de artillería y demás signos de júbilo.

Año a año las expediciones irían más lejos: en 1627, otro capitán Murad -un renegado alemán- llevó tres navíos argelinos hasta Dinamarca e Islandia, donde logró capturar cuatrocientos (otros dicen que ochocientos) cautivos; a partir de 1630 su presencia se hizo habitual en el canal de la Mancha. En 1631 su tocayo, el Reis Murad el flamenco, asola las costas inglesas, pasa a Irlanda y desembarca en Baltimore, saqueando la ciudad y llevándose cautivos a doscientos treinta y siete hombres, mujeres y niños, que son vendidos en Argel. Por entonces, los corsarios berberiscos realizan también incursiones a los bancos de Terranova en busca de pescadores ${ }^{23}$.

LOS CORSARIOS BERBERISCOS LLEGAN A GALICIA.

El ATAQue a la Ría de Vigo de 1617

En el siglo XVII volvieron a sonar en Galicia con renovada fuerza las incursiones de piratas y corsarios, pero esta vez el mayor peligro no procedía del Atlántico, sino del Mediterráneo. Los ataques de los corsarios nórdicos habían cesado o disminuido gracias al breve intervalo de calma con Inglaterra desde la muerte de Isabel Tudor con la paz firmada con Londres en 1604 (que sin embargo no evitó un ataque británico a Ribadeo en 1605); igualmente, la tregua con las Provincias Unidas en 1609 dio un buscado respiro a las cansadas armas españolas y holandesas. Pero entonces tomaron el relevo el corsarismo y la piratería berberisca, que provocaron una grave inquietud, atemorizando a las poblaciones

\footnotetext{
${ }_{22}^{2}$ S. E. Lane-Poole, Los corsarios berberiscos..., págs. 199-201.

${ }^{23}$ Ibidem, págs. 203-204; R. FeiJoo, Corsarios berberiscos..., pág. 126.
} 
de los enclaves costeros de Galicia, ya que la Monarquía Hispánica aún estaba en guerra con el Islam² ${ }^{24}$

Al cesar las hostilidades con Inglaterra y Holanda, los corsarios de estas naciones dejaron de actuar, al menos momentáneamente, en las aguas próximas a sus costas. Esto les llevó a desplazarse hacia el estrecho de Gibraltar, donde pronto serían bien recibidos por los turco-berberiscos, quienes con su apoyo conseguirían en adelante aumentar la frecuencia de sus incursiones en el Atlántico ${ }^{25}$.

Por otra parte, el alejamiento de la flota Real y el deterioro de los sistemas preventivos contribuirían a incrementar la presión corsaria en las costas gallegas, que experimentaría un importante crecimiento con el advenimiento de la piratería y el corso musulmán a partir de la segunda década del siglo XVII ${ }^{26}$. Una vez abierta plenamente la puerta del Atlántico, los turco-berberiscos pasaron a abordar cuantas embarcaciones de comercio descubrían a su paso y a asolar con harta frecuencia las desprotegidas poblaciones litorales de Galicia, primero sustituyendo en sus correrías a los corsarios europeos y después en franca competencia con ellos.

Estimulados por la gran densidad de pequeños e indefensos puertos que se encontraban en sus expediciones y protegidos por multitud de calas, entrantes e islas, los corsarios musulmanes convirtieron a sus habitantes en las nuevas víctimas de sus temibles razzias, apresando a marineros y pescadores que se aventuraban un poco más allá de playas y ensenadas. Sus apariciones eran repentinas, atacando por sorpresa y retirándose con igual agilidad, llevándose gran cantidad de cautivos cuyo destino era la esclavitud o la negociación del pago de su rescate.

No hay aún constancia exacta de en qué momento se produjeron los merodeos iniciales de turcos y berberiscos por las costas de Galicia, ni tampoco cuando y donde sucedió la primera incursión de sus naves, pero - sin descartar alguna posible correría anterior ${ }^{27}$ - probablemente debieron tener lugar a partir de la

\footnotetext{
${ }^{24}$ Manuel Artaza Montero, "Representación política y guerra naval en la Galicia de los Austrias", Anuario de Historia del Derecho Español, vol. LXVI (1996), pág. 448. Citan el ataque a Ribadeo, M. MurguíA, España. Sus monumentos y artes..., pág. 318, y E. Fernández Villamil, La Escuadra de Galicia ..., pág. 17. 25 B. Alonso Acero, Orán y Mazalquivir..., vol. I, pág. 29; "Entre el Mediterráneo y el Atlántico...", pág. 174.

${ }^{26}$ María del Carmen SAaVedra VÁzQuez, Galicia en el camino de Flandes: actividad militar, economía y sociedad en la España noratlántica, 1556-1648, Sada, A Coruña, Ediciós do Castro, 1996, pág. 140.

27 Una relación impresa y enviada en 1608 a Felipe III por un soldado español destinado durante más de 30 años en Orán, alentaba al monarca a mantener sus posiciones en el Norte de África, desde donde, a juicio del autor, mejor se podría controlar el desarrollo del corso y limitar el poder del Imperio turco: "porque por muchas razones conviene ansí al servicio de VM., por importar como le importan mucho aquellas plaças, para seguridad y guarda de la mayor parte de la costa y ámbito de España Meridional y Occidental desde cabo de Finisterra en Galicia, hasta lo más Oriental de la costa de Cataluña, y todas las Islas del mar Mediterraneo de V.M., lbiça, Mallorca, Menorca, Córçega, Cerdeña, Sicilia, Malta, y todas las demás del dicho mar estrecho, y las Canarias a la entrada del espacioso Oceano, a donde los corsarios de Argel han ydo ya dos o tres vezes, y han hecho alli pressas". B. Alonso Acero, Orán y Mazalquivir..., vol. I,
} 
segunda década del siglo XVII, y concretamente a lo largo del año 1617. Casi con seguridad, el primer gran asalto, y sin duda el más conocido y aparentemente más devastador de todos los que se produjeron en Galicia, fue precisamente el que tuvo como protagonista principal a la villa de Cangas de Morrazo en diciembre de 1617.

Se conocen bastante bien los acontecimientos del ataque ocurrido en Cangas porque en los días posteriores se realizó una pormenorizada información sobre el terrible suceso ${ }^{28}$. Esta relación, en la que se detallan de forma descarnada las crueles atrocidades allí cometidas, fue utilizada en febrero de 1618 por el concejo de la desgraciada villa para solicitar que fuese exonerada del impuesto de la sisa (sobre los alimentos), que debía pagar a la ciudad de Santiago, por entonces cabeza de su provincia ${ }^{29}$. Del mismo tiempo es también otra relación redactada por el sargento mayor de Cangas que desvela las circunstancias y las desavenencias habidas en el momento de organizar la defensa ${ }^{30}$.

Según apuntan los historiadores gallegos López Ferreiro y Fernández Villamil, este y otros ataques habrían sido motivados en parte como represalia a las repetidas derrotas infligidas por los españoles en una serie de campañas comenzadas paralelamente a la expulsión de los moriscos en 1601 que todavía continuaban en 1616.

Aunque no parece que haya sido esta la causa, dichos historiadores afirman que los navíos que arribaron a la ría de Vigo formaban parte de otra Armada mucho más grande, compuesta en origen por cien bajeles, que el sultán de Turquía, Achmed I (1590-1617) mandó aprestar para recorrer las costas de Sicilia y Calabria en venganza por los daños que le habían causado el Marqués de Santa Cruz (general de las galeras de Nápoles) y el almirante don Luis Fajardo en sus puertos y en sus escuadras ${ }^{31}$. Además, en julio de 1616, seis barcos de la flota del

págs. 53-54 y notas 105-108; "Entre el Mediterráneo y el Atlántico...”, págs. 176-177 y nota 12. Según Juega Puig, un navío de guerra holandés con base en Vigo divisó en septiembre de 1615, un navío pirata, posiblemente argelino, que llevaba una presa, que oligó a soltar. Juan JuEGA PUIG, El estanco de la sal en Galicia. Siglos XVI-XVII, Madrid, Ministerio de Agricultura, Pesca y Alimentación, 2006, pág. 404.

28 Bernardo Barreiro de VÁzquez Varela (ed.), "Información sobre la entrada de los turcos en la villa de Cangas y el daño que hicieron”, Galicia Diplomática, tomo I, núms. 1 (9-VII, págs. 7-8), 2 (16-VII, págs. 12-13), 4 (30-VII, págs. 29-31), 6 (13-VIII, págs. 46-47) y 12 (24-IX, pág. 92), Santiago, 1882. Según el editor, se trataba de un ms. inédito conservado en el Archivo del Ayuntamiento de Santiago.

29 E. Fernández Villamil, La Escuadra de Galicia..., pág. 17.

${ }^{30}$ Relazión de día mes y año de lo suzedido en la villa de Cangas en el mes de diciembre de 1618, Real Academia de la Historia, Colección de D. Luis Salazar y Castro, ms. N-51, fols. 1r. a 6v. El autor de la relación situa los sucesos de Cangas en diciembre de 1618 y no en el mismo mes de 1617, cuando realmente sucedieron. Probablemente fue escrita a principios de 1618 y a causa de la inmediatez de los acontecimientos el autor consignó este último año por error. C. Fernández Duro, Armada española..., pág. 356, la cita como "Relación de lo sucedido en la villa de Cangas, Manuscrito, Academia de la Historia. Colección Salazar, N. 50, fol. 1. ${ }^{\circ}$.

31 Antonio López Ferreiro, Historia de la Santa Apostólica Metropolitana Iglesia de Santiago de Compostela, vol. IX. Santiago, Seminario Conciliar Central, 1907, págs. 46-47; E. Fernández Villamil, La Escuadra de Galicia..., pág. 18. 
duque de Osuna, a las órdenes del capitán Francisco de Ribera, habían conseguido una gran victoria contra cincuenta y cinco galeras turcas en el cabo Kelidonia, en Levante, en la costa de la región turca de Karaman (cabo de Celidonia, en la costa de Caramania, para los españoles de la época). En el combate, que duró tres días, la flotilla de Ribera hundió una galera enemiga, dejando a dos sin mástiles y malparadas a otras diecinueve, huyendo todas las demás al reconocerse vencidas ${ }^{32}$. Este acontecimiento, según los citados historiadores, avivaría aún más el deseo de venganza de los turcos, cuyas naves, con inesperada osadía, trapasarían el Estrecho y -tras realizar otras incursiones- comenzarían a infestar el litoral de Galicia.

Las primeras noticias de que las embarcaciones corsarias se dirigían hacia las costas gallegas la dieron los portugueses, ante cuyo litoral se mostraban sin disimulo las naves berberiscas, obligando a sus habitantes a mantenerse vigilantes. A este efecto, la Cámara de Viana alertó al Concejo de Baiona con el fin de que tuviese tiempo suficiente para tomar las medidas defensivas necesarias ${ }^{33}$.

El 13 de mayo de 1617 ya rondaban por las Islas de Baiona (Cíes), pues desde esta villa se informó al Capitán General de Galicia, Marqués de Cerralbo, de que en ellas se habían dejado ver diez navíos corsarios, quienes abandonaron una embarcación de 150 toneladas después de tomar su carga, consistente en 1.500 fanegas de sal, y a un francés. Éste declaró que al dueño del barco y a los demás tripulantes los habían tirado al mar (!) o los llevaran cautivos a Argel, y que a él lo habían canjeado por otros dos hombres a unos ingleses. El Capitán General dio cuenta de ello al Rey en carta enviada el 18 de septiembre de 1617 desde Coruña $^{34}$. Confirma también la llegada de dichos corsarios un escrito del capitán del navío francés "Lama", dirigido al juez de Cangas, en el que manifiesta que se había acogido junto con otras embarcaciones al puerto cangués, por causa de los navíos de moros e turcos, que surgían en las Islas Cíes ${ }^{35}$.

Ambos testimonios confirman que antes de producirse el ataque hubo un reconocimiento previo del terreno para tantear el grado de vulnerabilidad de las poblaciones costeras gallegas, en este caso las de la Ría de Vigo, con el objetivo de sopesar sus posibilidades de éxito. Esta novedosa presencia musulmana en Galicia debe enmarcarse dentro del avance progresivo hacia el Norte -pasando

\footnotetext{
32 A. López Ferreiro, Historia de la Santa.... Sobre esta y otras campañas en el Mediterráneo, C. FernÁndeZ Duro, Armada española..., cap. XXI, "La Marina del Duque de Osuna (1611-1620)”, págs. 335-351, y Apéndices, pág. 494 y ss.

33 Carlos Vázquez Marinelli, José Moreira Pumar y Manuel Rodal González, Historia de Cangas, Pontevedra, Diputación Provincial de Pontevedra, Servicio de Publicaciones, 2007, pág. 292.

${ }^{34}$ Ibidem (cita AGS, leg. 822). Véase también J. Juega PuIg, El estanco de la sal..., pág. 404.

35 Ibidem. En el escrito, realizado ante el escribano de Cangas, Juan de Oitavén y dirigido al juez ordinario de esta villa, don Diego Vélez de Guevara, el capitán francés pedía que se le entregasen las velas de su nave para proseguir su viaje hacia el Reino de Portugal, puesto que el tiempo había mejorado y el enemigo abandonara ya las islas.
} 
por Madeira, Azores y la costa portuguesa- en el que los corsarios norteafricanos se hallaban inmersos una vez que se incorporaron plenamente a la navegación atlántica gracias a los avances técnicos antes citados. Como podrá comprobarse, la aparición de sus naves en el litoral gallego tuvo más que ver con una amplia estrategia a gran escala de las ciudades corsarias -en especial Argel-para extender su lucrativa actividad sobre espacios costeros más lejanos y productivos que con una coyuntural decisión política tomada por el lejano sultán de Turquía.

El domingo 3 de diciembre de 1617, fondeó en las islas Cíes una escuadra de moros y turcos, compuesta por once naves gruesas ${ }^{36}$, las cuales capturaron dos lanchas de pescadores que habían salido a la $\operatorname{mar}^{37}$. En realidad, la escuadra musulmana estaba formada por un total de catorce embarcaciones, de las que tres se mantenían vigilantes y a la espera en alta $\operatorname{mar}^{38}$.

Durante varios días los once navíos permanecieron estacionados en las Cíes, por lo que se creyó que habían arribado para surtirse de agua o reparar alguna avería $^{39}$.

36 "Información sobre la entrada de los turcos..."; Relazión de día mes y año de lo suzedido en la villa de Cangas...; "Certificación del Concejo de la villa de Bouzas a favor del capitán don Álvaro Pérez de Ceta por su actuación ante los corsarios turcos en la ría de Vigo", 1618, enero, 17.- Bouzas, Colección particular, en José Espinosa Rodríguez, Tierra de Fragoso (Notas para la Historia de Vigo y su comarca), Vigo, 1949, págs. 235-236. La "Información sobre la entrada de los turcos..." (declaración de Gerónimo Núñez, procurador general de la villa de Cangas), señala que fondearon el lunes día 4 y entraron en la ría 11 navíos, mientras que según la Relazión... y la "Certificación..." las naves fondearon el día 3.

${ }^{37}$ Carta del Marqués de Cerralbo a Felipe III, 1617, diciembre, 11.- Coruña, en C. VÁzquez Marinelli et al., Historia de Cangas, pág. 299.

${ }^{38}$ Carta del Marqués de Cerralbo a Felipe III, 1617, diciembre, 17.- Coruña, AGS - GA, leg. 822, en M. C. SaAvedra VÁzquez, Actividad militar, economía y sociedad en la España noratlántica, 1556-1648, tesis doctoral, Universidad de Santiago, 1992, pág. 345 y nota 128 (Declaración de un renegado cristiano capturado); también en C. VÁzquez Marinelli et al., Historia de Cangas, pág. 300. Confirma el número de 14 navíos corsarios la Relazión de día mes y año de lo suzedido en la villa de Cangas...

${ }^{39}$ Nicolás TABOADA y LEAL, Descripción topográfico-histórica de la ciudad de Vigo, su ría y alrededores, Santiago, Imp. de la Viuda e Hijos de Compañel, 1840, pág. 191; Francisco Ávila y La CuEva, Historia civil y eclesiástica de la ciudad de Tuy y su Obispado, tomo $1^{\circ}$, Tuy, 1852, fols. 398-402. Los relatos de Taboada Leal y de Ávila y La Cueva se basan en la, Ynformación que á cerca de esta obcurrencia dió judicialmente el Procurador General de dicho Vigo el Licenciado Don Pedro Falcón de Castro en 12 de Enero del año siguiente 1618, en la que declararon ocho testigos que presenciaron la refriega desde su principio hasta su fin, todos ellos no vecinos de Vigo, personas de su posición como Párrocos y otros sujetos de carácter, cuya aprovó el motivado capitán comandante Don Pedro de Guevara por medio de auto que proveyó en ella. El original de dicha información estaba en poder de Taboada Leal quien se la facilitó a Ávila y La Cueva, el cual dice que también utilizó otras fuentes, como la citada Certificación que dió el concejo y ayuntamiento pleno de la Villa de Bouzas con fecha de 17 de Enero de 1618 al Don Álvaro Pérez de Zeta, cuyo originalmente conserva en su archivo don José María Espinosa, vecino de la Villa del Porriño, como descendiente del Zeta, papel que Ávila y La Cueva tuvo oportunidad de leer y documentarse. Asimismo, acerca de esta expedición, este autor encontró, una especie en el archivo del Marqués de Mos: y es un testamento que suena otorgado en 15 de Junio de 1618 por Juan da Veyga, escribano de la Villa de Cangas hallándose cautivo en la Ciudad de Argel, y entre los testigos que en él pone, que son muchos, 
No obstante, apercibidos del peligro de un inminente ataque, las poblaciones que se asomaban a la ría se prepararon para la defensa. En Cangas, habiéndose recibido la noticia en la noche del domingo, el sargento mayor de la villa mandó dar aviso a su superior, el cabo de las milicias del partido de Pontevedra, don Payo de Montenegro, para que movilizase a las compañías de su jurisdicción y viniese a socorrer y reforzar con ellas los puertos de la misma, por ser muchos y estar abiertos. Además, a medianoche, el citado sargento mayor envió un barco a Vigo con el fin de alertar a su homologo de la villa de Vigo, don Pedro de Guevara, para que se aperziviesse y avisase a los puertos de su partido, teniendo buena correspondenzia para acudir al serviçio de Su Magestad ${ }^{40}$. Por su parte, los capitanes de la villa de Cangas y su tierra reunieron a la gente de sus compañías e intentaron, repararla lo mejor que pudieron ${ }^{41}$.

Sin embargo, don Payo de Montenegro se demoró tres días en acudir a la villa de Cangas, y tampoco trajo con él ninguna fuerza armada para socorrerla. Una vez el sargento mayor le persuadió del riesgo y de la necesidad de refuerzos, Montenegro envió entonces a buscar dos compañías, una de Marín, con unos 50 hombres y sin capitán, porque dixo estava enfermo, y otra de la feligresía de los Cobres y Vilaboa, de la cual era capitán Domingos Prego, vecino de la villa de Pontevedra ${ }^{42}$.

Por fin, el jueves 7 de diciembre, víspera de la fiesta de Nuestra Señora de la Purísima Concepción, los once navíos turco-berberiscos se dieron a la vela y se internaron ordenadamente en la desprotegida ría, mientras las tres embarcaciones restantes seguían centinelas fuera de ella.

Al ver acercarse a los buques corsarios, la alarma cundió en Vigo, cuyos atemorizados vecinos se sintieron compelidos a acogerse al patrocinio de la Purísima,
...sacando la imagen que había en aquella Colexiata con Nuestra
Señora del Rosario, cofradía unida a la del Sacramento en procesión y rogativa y clamor en las calles pidiendo misericordia y piedad a Dios y su intercesión para librar a esta villa y a sus moradores de la esclavitud de los sarracenos enemigos de nuestra santa fe católica ${ }^{43}$.

\footnotetext{
nombra á algunos que eran naturales del mismo Cangas y alli estaban con el testador, que sin duda todos ellos fueron hechos cautivos en la presente invasión del Turco.

40 Relazión de día mes y año de lo suzedido en la villa de Cangas...

41 "Información sobre la entrada de los turcos...", (declaración de Álvaro de Aballe, canónigo de la catedral de Orense y comisario apostólico, residente en la villa de Cangas).

${ }^{42}$ Relazión de día mes y año de lo suzedido en la villa de Cangas...

43 Documento de la Casa de Pajarín, en C. VÁzquez Marinelli et al., Historia de Cangas, pág. 297.
} 
Los barcos enemigos se dirigieron hacia Bouzas y, acometieron a esta villa y la cañonearon con toda la artillería que tradýan y con lanzas y mosquetería ${ }^{44}$. A continuación, los corsarios echaron al agua nueve o diez lanchas con gente armada de mosquetes y vinieron costeando con intención de realizar un desembarco, pero la villa se defendió bien. Ese mismo día, llegó en su auxilio, siguiendo los movimientos de los corsarios, el capitán don Álvaro Pérez de Ceta con su compañía y algunos hidalgos agregados a ella con orden de Diego de Grijalba, capitán de la gente de guerra de Baiona y del obispado de Tui. Los musulmanes, viendo frustrado el desembarco, se retiraron con sus lanchas costeando desde Bouzas a Vigo, hacia donde también fue en su seguimiento la compañía del capitán Pérez de Ceta ${ }^{45}$.

Los corsarios fueron aproximándose hasta el cabo de A Laxe-que ya se había fortificado con piezas gruesas y mosquetes-y volvieron a intentar un desembarco, pero se encontraron con la fuerte resistencia de los soldados de las compañías y paisanos que cubrían aquella posición. Obligadas de nuevo a retirarse, las lanchas se dirigieron, protegidas por su escuadra, hacia el Areal, en aquel tiempo despoblado, situándose frente el convento de religiosas del arrabal. Aproximándose a la orilla cuanto les fue posible, los musulmanes repitieron la tentativa de desembarco, intensificando sus esfuerzos para tratar de saltar a tierra; pero aunque en este sitio no se les pudo oponer baterías ni parapetos, la gente de tierra, ayudada de los arcabuces y piezas de los que defendían la batería de A Laxe, consiguió rechazarlos entablándose un vivo tiroteo en medio de insultos y provocaciones que estuvo a punto de llegar al cuerpo a cuerpo.

La pelea en el cabo de A Laxe y en el Areal duró más de cinco horas, concurriendo también a la defensa los paisanos de los alrededores y algunas personas principales de la villa con sus criados. El juez ordinario de Vigo, Gaspar Méndez de Sotomayor, y el procurador general, Pedro Falcón de Castro, que también lucharon en las baterías, se ocuparon de dar todo el abasto y mantenimientos necesarios a los defensores de la plaza.

En vista de que la situación les era adversa, y habiendo herido a tan sólo tres o cuatro soldados, los asaltantes desistieron, dejando su nave Capitana fondeada frente a Vigo para dirigirse hacia el interior de la ría, al puerto de Teis, con el mismo objeto de quemarlo y robar y cautivar a su vecindario junto con los demás lugares inmediatos.

El capitán don Pedro de Guevara, caballero del hábito de Cristo y comendador de Santa Marina de Lisboa, dirigió la defensa como gobernador y sargento mayor de la gente de guerra de Vigo, Bouzas, Redondela y sus distritos. Guevara ordenó que los capitanes Fajardo y Pereira con sus respectivas compañías, y otra

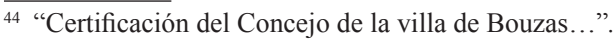

45 Ibidem.
} 


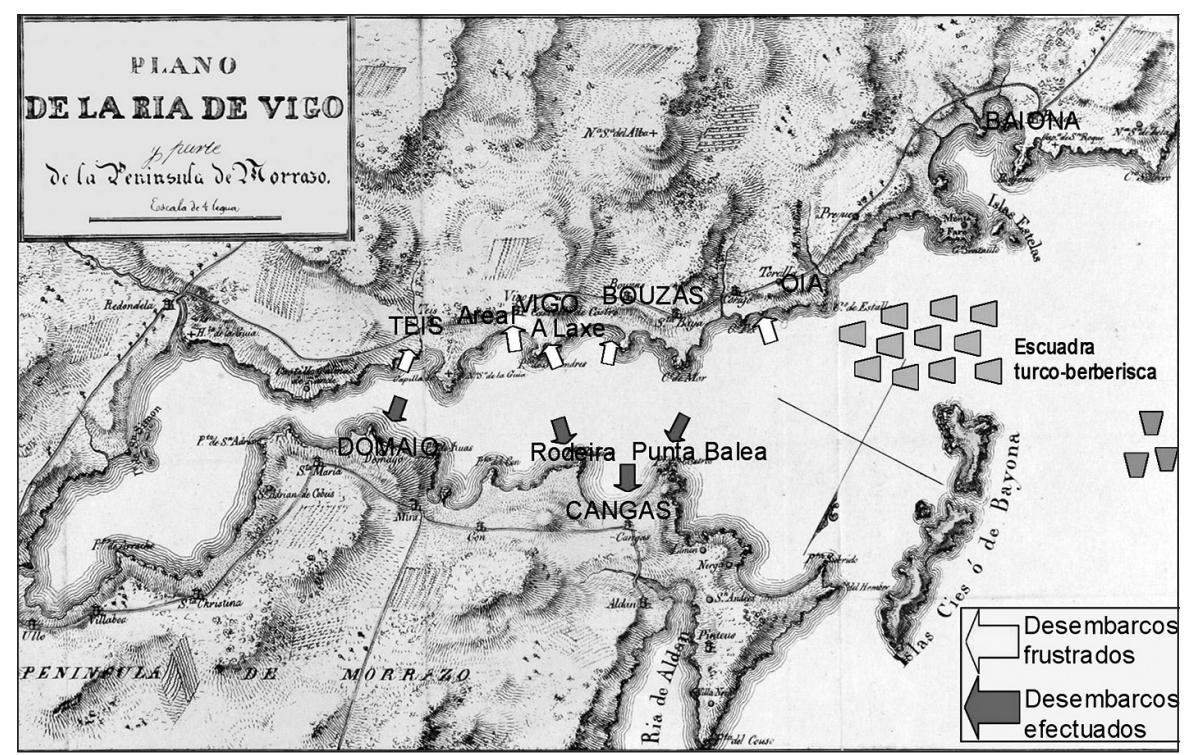

Fig. 1. Puntos de ataque y desembarco de los corsarios turco-berberiscos en la ría de Vigo. Fuente: elaboración propia.

que llevó el alférez don Juan Arias de Arbieto, marchasen a lo largo de la orilla de la ría sin perder de vista al enemigo y lo siguieran hasta el punto al que se dirigiese. Todos ellos hicieron alto en Teis, donde impidieron el desembarco de los norteafricanos y la captura de tres navíos portugueses procedentes del Brasil refugiados en el puerto de Cedeira (Redondela) ${ }^{46}$.

Después de fracasar su desembarco en la orilla sur de la ría, los corsarios dirigieron su mirada hacia el lado contrario de la ría considerando que la hallarían más desguarnecida.

En las primeras horas del viernes 8 de diciembre, festividad de la Inmaculada, los turco-berberiscos desembarcaron en gran número y sin encontrar resistencia

\footnotetext{
$\overline{46}$ N. TaBOADA Y LeAl Descripción topográfico-histórica..., págs. 191-193; F. Ávila y La Cueva, Historia civil y eclesiástica ..., fols. 398-402. También pueden consultarse las versiones de José SANTIAGO Y GómEZ, Historia de Vigo y su comarca, Madrid, Imprenta y litografía del Asilo de Huérfanos, 1896, págs. 343349; y J. Espinosa Rodríguez, Tierra de Fragoso ..., págs. 235-237. No obstante, en la Historia Cangas, se informa que los corsarios pretendían aproximarse a Vigo para robar las mercancías de los navíos allí fondeados, consiguiendo entrar en una carabela portuguesa fondeada cerca de tierra: ...La gente de $m i$ compañia, escaramuzando con ella haziendo retirar al dicho enemigo. El qual abiendo entrado gente suya en una carabela questaba en tierra para robarla, y abiendo allado dentro della un portugués marinero lo llebaron cautibo, y bisto lo suso dicho por el dicho Bernardino Soto Cabral se metió en un batel que estaba a orilla de la mar. Historia Cangas, pág. 301 (cita APSC., Libro F, hoja de escribano anexada a la última página. Este documento fue trasladado al AHDS, donde no se pudo consultar por no estar permitido a causa de su deterioro.
} 
en la parroquia de San Pedro de Domaio, donde según la "Información" se les hizo frente por parte de algunos vecinos y por las compañías de Cangas ${ }^{47}$. Sin embargo, el sargento mayor de esta villa afirmó que siendo necesario mandar refuerzos a Domaio, don Payo de Montenegro se negó a despachar hacia allí una compañía, y no quiso enviar, más de veinte hombres por una horden por escripto, en vista de lo cual el citado sargento mayor decidió mandar por su cuenta otros veinte hombres:

y visto esto emvié yo veinte hombres más sin que él lo supiese con un alférez que se dize Juan Costas y un cabo desquadra que se dize Juan Domínguez los quales dijeron que se le avía huido la mayor parte de la jente, y acudiendo el abad de Domayo a que le diese más jente no se la quisso dar aunque yo le persuadí que lo hiziesse $e^{48}$.

En el enfrentamiento, los corsarios mataron y cautivaron a siete personas y quemaron parte de la feligresía, llevándose mucho ganado. Vueltos a sus naves, los corsarios se dieron a la vela retrocediendo hacia Vigo. Al aproximarse a este puerto volvieron a repetir sus disparos contra él, echando algunas lanchas al agua para intentar otra vez el desembarco, siendo rechazados de nuevo con igual tesón. En consecuencia, ese viernes día 8 todos los buques de la escuadra turca se fueron a anclar ante la villa de Cangas (frente a la que ya dejaran dos naves después de entrar en la ría), permaneciendo allí reunidos toda la noche ${ }^{49}$.

Entretanto, el viernes por la tarde, al ponerse el sol, llegaron a Cangas las citadas compañías de Marín y de los Cobres y Vilaboa. La primera, compuesta de cincuenta a sesenta hombres, venía sin capitán, sólo gobernada por un sargento mayor llamado Fernando de Romay Troncoso, y un alférez; después llegó la segunda, capitaneada por Domingos Prego, organizándose el alojamiento de ambas fuerzas, que sumaban doscientos hombres poco más o menos, y asignándoseles los puestos que habrían de defender. Lo mismo se hizo con las demás compañías de la villa y tierra de Morrazo, que junto con las anteriores hacían un total de cinco, las cuales fueron repartidas de la forma siguiente:

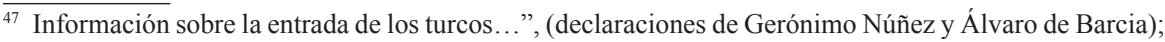
Bernardo BARreiro, Brujos y Astrólogos de la Inquisición de Galicia y el famoso libro de San Cipriano [1885]. Madrid, Ed. Akal/Arealonga, 1973, pág. 146. Según este autor, la gente marinera, a las órdenes de los capitanes Pedro Costas Franco y Pedro Bermúdez de Sotomayor, y del alférez Domingo Pérez Hurtado, acudió a la defensa, sin otro resultado que una huida forzosa y siete muertos en la playa.

${ }^{48}$ Relazión de día mes y año de lo suzedido en la villa de Cangas...

49 "Información sobre la entrada de los turcos...", ibidem; N. TABOADA y LEAL, Descripción topográfico-histórica..., pág. 192-193; F. Ávila y La Cueva, Historia civil y eclesiástica..., fol. 400.
} 
La compañía de Cangas, del capitán Pedro Bermúdez, quedó de guardia en la villa en junto con 50 hombres de la de Marín; la del capitán Pedro Costas se colocó, sobre el muelle que está en la defensa de los zercos de pesca porque no llegase el enemigo a quemallos; la del capitán Geronimo Núñez se posicionó, sobre el cavo de Valea que esta arrimado a la dicha villa para que estuviese de zentinela para que viesse lo que pasava de la otra parte del dicho cavo; y la compañía de Domingos Prego fue situada, en la playa de Rodera y río del Señal* puesta en un bolante.

Esta distribución hubo de hacerse con urgencia, tan sólo, dos o tres horas antes del día, tocando a arma por aver visto y reconoçido que el enemigo andaba a la bela sobre el cabo de Valea sondando con las lanchas ${ }^{50}$.

El sargento mayor preguntó a los mandos de las dos compañías recién llegadas si venían con la munición necesaria, a lo que respondieron que sí; su intención era asegurarse de que dispondrían de la suficiente, que él mismo había fabricado en parte con la ayuda de su hijo:

porque yo tenía tres barriles de pólbora y medio quintal de cuerda y plomo y valas echas las quales estube yo propio y un hijo mío un día y una noche haziendo las dichas valas de mosquete y alcabuz la qual muniçión toda hiçe repartir y mandé a todos los soldados de mi distrito aderezasen y aperziviesen las harmas y para ello les siñalé dos çerrajeros para que no hiçiesen otra cosa sino ponellas en razón y les puse pena de tres tratos de cuerda en no haziendo lo que les hordenava,

Para afirmar su autoridad y mantener la disciplina, el sargento mayor hizo poner a un lado de la plaza de armas, un mástil con una polea y una cuerda, para hacer castigar a aquellos que no quisieran obedecer las órdenes en servicio de S.M. Después organizó a los hombres disponibles y para mayor protección mandó abrir una trinchera,

cubriendo la villa toda con ella donde metí toda la jente que me parezió que era comviniente para la defensa y hiçe haçer un esquadron y hiçe los troços nezessarios conforme a la cantidad de la jente y a la pusibilidad de la tierra, y pusse pena de la vida a todas

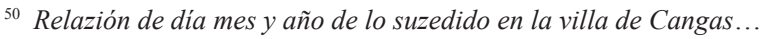

* Se refiere a la playa de Rodeira y al río Bouzós, también conocido por río do Sinal, que desembocaba en esa zona y discurría bajo un puente medieval.
} 
las personas que después de nombrados sus puestos y reconozidos los dexasen y desamparasen si no fuese con orden del cabo o mía en su nombre...

Pero todas estas iniciativas no fueron del agrado de don Payo de Montenegro, quien cuando llegó a Cangas amonestó al sargento mayor,

\begin{abstract}
porque avía echo las tales previnziones dichas arriba que yo como soldado avía hecho y hiçe lo que me pareze que hera justo y lo qual todo me contradezía el cabo, y tanto que teníamos devisiones cada día y cada momento sobre ello, y llegado a querer yo tomar y azer protestar y tomar testimonio contra el dicho cabo, no quiso ningún escrivano hazerlo.
\end{abstract}

De las palabras del sargento mayor se infiere que existieron importantes desavenencias entre éste y Payo de Montenegro en cuanto a la determinación de la estrategia a seguir, lo que sin duda provocaría una grave falta de coordinación y confianza a la hora de ejercer el mando y organizar los efectivos disponibles. A lo anterior habría que añadir también la manifiesta hostilidad existente - no sabemos la causa- entre el sargento mayor y los capitanes de las compañías, que no dudaban en desafiar la autoridad del sargento mayor:

y por la propia razón no me querían los capitanes obedezer, ni offiçiales ni la demás jente las hórdenes que les dava diçiendo que no me querían ovedeçer porque no tenía nombre de sarjento mayor, sino una plaça marítima, y diçen que no an menester nadie que les enseñe y administre que ellos son muy grandes soldados, y digo que es verdad (pero para huir) como se ha visto en esta ocassión y tanto que aviéndome hordenado el cavo don Payo el viernes en la noche que le diese por horden al cappitán Gerónimo Núñez que fuese con su compañía al cabo de Balea, no quiso hir diziendo que yo mandava mucho y que no savía lo que me hazí, y tanto que el dicho capitán y su alférez se fueron al cabo y le dixeron que si era horden suya que fuesen al cavo de Balea con su compañia, les riñó y dixo que era mal hecho no ovedeçer las hórdenes que les dava pues el sarjento mayor era boz suya del dicho cavo y que las hórdenes nazían del aunque yo las dava, todo esto pasó delante del cappitán Juan Mariño y don Gerónimo de Saabedra, los quales se hallaron presentes. 
(...) Otrosí el cappitán Gerónimo Núñez ni los demás quisieron obedezer las hórdenes que les dava como dicho tengo arriva, y tanto que se fueron a quexar al cavo para que mandase que no hiçiesse alarde ni administrasse la jente sino de tres a tres meses, yendo contra las hórdenes y mandatos de Su Magestad y de los capitanes generales deste Reino, yendo en todo contra las instruziones suyas a las quales me refiero. El qual dicho cavo mandó una horden por escripto sinada e firmada por él para que yo no hiçiese los alardes conforme manda Su Magestad ${ }^{51}$.

Esta circunstancia inoportuna, en un momento en que la unidad de acción y la disciplina eran cruciales para afrontar con un mínimo de garantías el grave enfrentamiento que se avecinaba, probablemente dificultó, sino impidió, la constitución de una resistencia más efectiva que quizás habría podido evitar o paliar el desastre.

Pocas horas antes de producirse el esperable ataque corsario, encontrándose el sargento mayor en la playa de Rodeira y río do Sinal (por donde suponía que desembarcaría el enemigo) con la compañía de Domingos Prego, llegó el alférez Domingos del Río con orden de Payo de Montenegro para que hiciese retirar la dicha compañía a la villa, que assí combenía al serviçio de Su Magestad.

El sargento mayor obedeció, pero, diçiéndole al cavo que beía mal retirada por ser la parte más peligrossa y flaca. Montenegro por su parte le replicó simplemente que lo que él había ordenado, estava muy bien hecho.

En la madrugada del sábado día 9, en el ynter que venía el día, el sargento mayor mandó a la compañía del capitán Prego que se posicionara en la trichera y se fue a visitar otras compañías, dirigiéndose adonde estaba la del capitán Gerónimo Núñez, situada sobre el cabo da Balea. El oficial ordenó a Núñez, que tuviesse grande quenta con unas lanchas que andaban sondando por allí, y que de lo que hubiese le diese aviso a Payo de Montenegro o a él con el fin de decidir lo más conveniente para la defensa, y que si él o el cabo enviasen alguna orden la pusiesen en ejecución inmediatamente.

Después, el sargento mayor regresó a la trinchera de la villa y al poco se hizo de día, momento en que los corsarios musulmanes procedieron a iniciar el ataque con intención de ejecutar un desembarco, poniéndose los navios dellos y un navio pequeño con siete lanchas reforçadas de moros y renegados mosqueteros $y$ flecheros, $y$ onbres corredores con alfanjes en las manos.

51 Ibidem. 
Don Payo de Montenegro ordenó entonces al sargento mayor que enviase a los arcabuceros de la compañía del capitán Domingos Prego a contener el desembarco, justo en el mismo punto del que horas antes había mandado que se retirasen dejándolo desguarnecido:

y visto que ponían en execuzión el benir a tierra a desembarcar, me ordenó el cabo que ymbiase çinquenta arcabuzeros la compañía de Domingos Prego y él con ellos a defender la dicha desembarcazión a la playa de Rodera y río del Señal el qual fue con él un capitán reformado que se diçe Juan Marino y quatro mosqueteros de la villa y emvié sesenta arcabuzeros y los quatro arcabuçeros, que son catorze más de los que mandó el cavo, a los quales ordené que les disparasen a las lanchas y defendiesen la desembarcazión, y antes dixe al cappitán Domingos Prego y assus offiçiales si benían prevenidos de muniçiones, y me dixeron que sí, los quales dispararon a las dichas lanchas...

Sorprendidos por esta resistencia inicial, los corsarios, se retuvieron un poco, pero no tardaron en enviarles desde la nave Capitana otras dos lanchas de socorro, en las quales vino un bergantín con dos esmeriles en la proa.

Gracias a estos esmeriles - dos piezas de artillería pequeñas algo mayores que un falconete- los corsarios consiguieron realizar el desembarco con sus lanchas y gradualmente empezaron a tomar tierra. El sargento mayor acudió a ayudar a los arcabuceros yendo en su socorro con el resto de la compañía del capitán Prego (más de ochenta hombres y dos mosqueteros de la villa), pero los ánimos de los defensores flaquearon, iniciándose una desbandada general que el citado sargento se vio incapaz de contener, confesando éste, después, que sintió tanta vergüenza y desesperación que llegó a pensar en suicidarse:

y en este tiempo me huyeron todos que no fui poderoso para podellos contener ni por bien ni por mal ni a cuchilladas (...)

y çiertos labradores que eran del capitán Gerónimo Núñez, de la feligresía de Aldán, entre los quales yba un labrador que se diçe Bartholomé Donores, que me bieron él y los demás que yban huyendo por el monte como andava yo por el río del Señal rebuelto con los moros, y visto una tan gran cobardia, me quisse arrojar en la mar sino fuera por perder el alma de puro aburrido, pero eché de ber que no restauraba nada de la pérdida y que hera tentar a Dios. 
Con la intención de tratar de reorganizar la defensa, el sargento mayor se volvió hacia la villa, donde estaba instalada la plaza de armas, en la que había quedado al mando dirigiendo las operaciones don Payo de Montenegro, pero cuando llegó,

avía huido el cavo y la demás jente con él, y no hallé en ella sino dos franzeses que estaban bendiendo trigo y a un hijo mío que me llebaron cautibo y al prior de la yglesia de la villa y otras tres o quatro personas que avían quedado por allí.

La huída de la primera autoridad militar de Pontevedra y de todo el Morrazo había terminado por desarticular la organización de la defensa y hundir toda tentativa de resistencia, provocando que el sargento mayor montase en cólera al enterarse de su deshonrosa actitud:

y el cabo huyó delante dellos el qual dizen que yva desanimando la jente y diziéndoles que valiesse quien pudiese, que yo no lo ví ni oý porque él estava en la plaça de armas con la jente que en ella avía, yo estava metiendo el socorro por la puente del Señal que fue quando todos huyeron, que yo prometo que si le viera o oyera las tales razones le matara antes que saliera de la plaça.

El sargento mayor envió a llamar entonces a los capitanes Gerónimo Nuñez y Pedro Costas (situados al principio en el cabo da Balea y en el muelle), para que viniesen a meter socorro. Pero sin embargo, visto que las demás huían no quisieron sino huir tamvién, de manera que no cumplieron la orden. Exasperado, el sargento mayor se fue espada en mano contra la gente que se batía en retirada conminándoles a dirigirse a la plaza de armas,

y viniendo dando bozes y dando de cuchilladas a la jente que huía encontré con el alférez de Marín con su bandera y su jente, que yvan huyendo, y embestí con el dicho alférez y le quité la bandera, $y$ dándole de cuchilladas le hize bolver a la plaza de harmas, y llegando a ella hallé a un hijo mío solo en la trinche $<r>$ a y al cappitán Pedro Costas y su alférez, y a un labrador que se diçe Pastorica, por averle huido la demás xente y desamparádole.

El capitán Gerónimo Núñez había huído, por ençima de la villa por unos montes y con su bandera y toda su compañia, y el propio sargento mayor hubo de 
renunciar a la lucha cuando, corriendo a los enemigos, se encontró con el capitán Juan Mariño que venía en retirada. Con él llegó al cuerpo de guardia de la plaza de armas, donde hallaron una bandera del capitán Pedro Costas que había sido abandonada en la desbandada. Mariño tomo la bandera al prior de la iglesia, que la tenía en la mano dando boçes, y a su vez el sargento mayor la tomó al capitán, dando él mismo voces y clamando al cielo por la deserción que se había producido, rodeado por los pocos que aún se iban batiendo en retirada:

De esto fueron testigos el prior de la iglesia y San Juan de Romay, racionero de la Colegial, y Pedro Dorado, clérigo, y San Juan de Refoxos y el capitán Juan Mariño y Duarte Núñez y otros tres o cuatro labradores que en los quales me acuerdo que yva el cavo de esquadra Juan Domínguez, de la feligresía de San Tomé de Pinero, el qual me vido en la mariña y plaça de armas después de aver huido toda la jente con la bandera que saqué del cuerpo de guarda, los quales me vieron dar bozes y me oyeron pidiendo justiçia al zielo y que me fuesen testigos de tan grande maldad y vellaquería de cómo todos huyeron y me dexaron solo.

Entretanto aparecieron los corsarios moros corriendo hacia ellos y obligándoles a huir a su vez, no sin antes recoger las demás banderas que allí se hallaban. Saliendo de la villa, el sargento mayor alcanzó a un muchacho que llevaba en sus manos la cruz grande de plata de la iglesia, de valor de más de ochocientos ducados,

y visto que los moros nos benían apretando y que era yo el postrero, le quité la dicha cruz al muchacho porque no la llebasen los moros, y bolviendo la cabeza atrás vi de cómo los moros llebavan al muchacho, que quedava dando bozes, que no le pudimos valer, y llevé la dicha cruz y la pusse en salvamento, y esto lo hiçe porque entendi hazía serviçio a Dios.

Una vez a salvo, el sargento mayor, fue consciente de que él mismo era uno de los principales responsables de la defensa, y como tal de su pérdida, por lo que, al ser acusado, no dudó en defenderse, descargando sobre su inmediato superior, Payo de Montenegro, la responsabilidad final de la derrota, achacando el fracaso a la inoperancia de sus órdenes, de las que el sargento decía ser un mero ejecutor, y a su deshonrosa huída del campo de batalla: 
...y assí en todo y por todo lo gobernava, yo no hazía nada sin sus hórdenes estando él allí, y assí quando huyeron fue el dicho cavo de los primeros y todos con él y me dejaron solo y como solo no pude resistir, que al fin un hombre es un hombre, de lo qual an ynformado algunos y jurado lo que no bieron porque yban huyendo por los montes, y assí, por salbarsse an jurado contra mí como forastero, valiendo al cabo que es de su natural ${ }^{52}$.

Pero veamos cuales fueron los sucesos ocurridos en la villa de Cangas según el resto de las fuentes conocidas hasta el momento sobre este ataque:

Al amanecer del sábado día 9, entre las siete y las ocho de la mañana, los corsarios musulmanes subieron a sus lanchas y saltaron a tierra bajo el fuego de artillería de sus naves, acometiendo la villa,

más de mill moros y turcos mosqueteros armados con coseletes y otros con flechas, lanças y alfanges, a cuya potencia no se pudo resistir por la gente de la dicha villa e su tierra que estava en su defenssa por ser puerto marítimo sin muralla, artillería, fuerte ni defenssa alguna ${ }^{53}$.

El cabo de las milicias del partido de Pontevedra, Payo de Montenegro, que había acudido con sus hombres al conocer la amenaza, consideró que no podría resistir, por lo que se retiró y escribió al Capitán General manifestándole que ante la imposibilidad de oponerse al enemigo había preferido regresar a Pontevedra, justificando su decisión con la excusa de que no podía dejar esta villa desprotegida $^{54}$.

Encontrando poca resistencia, una parte de los corsarios desembarcó con siete lanchas en la playa de Rodeira, delante de la villa, al tiempo que otro grupo, para rodearla, tomaba tierra con cuatro lanchas en la punta da Balea ${ }^{55}$. A pesar del intento de defensa organizada por los capitanes Pedro Costas Franco y Pedro Bermúdez de Sotomayor, y el alférez Domingo Pérez Hurtado, quienes murieron

\footnotetext{
52 Ibidem.

53 "Información sobre la entrada de los turcos...", (declaraciones de Gerónimo Núñez y Álvaro de Aballe).

${ }^{54}$ Carta del Marqués de Cerralbo a Felipe III, 1617, diciembre, 11.- Coruña, en C. VÁzquez Marinelli et al., Historia de Cangas, pág. 299. Por esta causa, Montenegro habría sido destituido de su cargo acusado de grave abandono de sus funciones y de incompetencia militar. C. VÁzQuez Marinelli et al., Historia de Cangas, págs. 303-304.

55 “Información sobre la entrada de los turcos...”, (declaración de Álvaro de Aballe).
} 
en la refriega, la resistencia fue inútil. En el puerto fueron incendiados los barcos fondeados en él, quedando destruidas las embarcaciones de pesca de la villa ${ }^{56}$.

Los atacantes cayeron sobre los habitantes de Cangas mostrando una extraordinaria crueldad y brutalidad, seguramente en castigo por el inicial intento de resistencia mostrado, y así, amparados los corsarios por su mayor superioridad numérica, armamento y experiencia de combate,

robaron el dicho pueblo e bienes que en el avía y quemaron más de ciento y cinquenta cassas, que heran las mejores y de los hombres más ricos de la dicha villa y las que tenían el dicho lugar en ser. Las demás que quedaron en pie fueron robadas y saqueadas, que en ellas no quedó cossa alguna ${ }^{57}$.

También saquearon e incendiaron la iglesia colegiata (que tenía un prior y seis racioneros), haciendo pedazos las imágenes, cruces y retablos y las campanas, llevándose los frontales, los ornamentos y las lámparas de plata:

...quemaron el retablo donde se ponía el Santísimo Sacramento con un Cristo grande y otras imágenes de santos de bulto con otras siete capillas que avía en la dicha yglesia y quemaron el coro della y retablos de las dichas capillas y sacristía con la torre de las campanas y relox, y quebrantaron en pedazos las dichas campanas $y$ relox, que el hedificio de todo ello balía más de quatro mill ducados sin los ornamentos y custodia e encensario, cálices y más plata que han llebado y robado de la dicha yglesia.

Asimismo, de los cajones de la colegiata, se llevaron,

más de diez quintales de cera de siete cofradías que en ella avía y cinco pendones de damasco de colores con sus cruses de plata de serbicio de las dichas cofradías con muchos vestidos de seda de las ymágines de Nuestra Señora del Rosario y de la Paz, frontales de seda y otros ornamentos de valer todo ello de más de mill ducados $^{58}$.

\footnotetext{
${ }_{56}$ C. VÁzquez Marinelli et al., Historia de Cangas, pág. 302.

57 “Información...” (declaraciones de Álvaro de Avalle y Gerónimo Núñez).

58 Ibidem (declaraciones de Álvaro de Avalle y Gerónimo Núñez).
} 
Como nota curiosa, en la Visita pastoral hecha al arciprestazgo de Morrazo en 1651, se informó que en la capilla del Buen Jesús de la iglesia colegiata se veneraba la imagen de,

un Sancto Cristo de mucha devoçión, a quien aunque los moros quando ocuparon a Cangas metiendo el Santo Cristo de propósito en paxares para quemarle, por algunas veces tirándole de mosquetazos y otras cosas, no le pudieren quemar, quedando la santa ymagen del Crucifixo libre de dicho incendio, ni los mosquetazos penetraron el santo crucifixo ${ }^{59}$.

Después derribaron el crucero con la imagen de la Piedad situado en el atrio, frente a la entrada principal de la colegiata ${ }^{60} \mathrm{y}$ a continuación entraron en el inmediato hospital de pobres y peregrinos de la villa y lo quemaron,

\begin{abstract}
con su capilla y retablo y muchas ymágines, y dél llebaron y robaron setenta libras de sera labrada, veinte arrobas de azeite, muchas mantas y sábanas de servicio del dicho hospital, dos bestidos de seda de la ymágen de Nuestra Señora con su corona de plata de valor todo ello con los hornamentos que en el dicho hospital avía de más de quinientos ducados ${ }^{61}$.
\end{abstract}

Una vez saqueada la villa, los corsarios se extendieron por la comarca saqueando las iglesias parroquiales vecinas. En Darbo robaron los cálices, vinajeras, candelabros de bronce y los ornamentos de las cofradías, pero aún fue mayor el valor de lo destruido, pues arruinaron la fachada de la iglesia y el campanario, llevándose las campanas. En Hío saquearon la iglesia de San Bartolomé, edificada pocos años antes, pero no pudieron llevarse nada de valor, sin embargo los destrozos ocasionados, ascendieron, según sus cofrades, a 24 reales de plata. También asaltaron la inmediata parroquia de Santa María de Cela, donde capturaron a un labrador llamado Juan González ${ }^{62}$.

Incluso aún considerando una posible exageración de los sucesos y sobre todo del número de muertos, el balance de destrucción y saqueo material de la

\footnotetext{
$\overline{59}$ José Manuel VÁzQuEz Luó, La Matrícula de Mar y sus repercusiones en la Galicia del siglo XVIII, tesis doctoral, Universidad de Santiago, 2005, pág. 75, nota 92 (cita Archivo Histórico Diocesano de Santiago (AHDS), Visita Pastoral al Arciprestazgo de Morrazo, leg. 1.264, fol. 133r.).

${ }^{60}$ C. VÁzquez Marinelli et al., Historia de Cangas, pág. 302.

61 "Información sobre la entrada de los turcos...", (declaración de Gerónimo Núñez).

62 C. Vázquez Marinelli et al., Historia de Cangas, págs. 302-303.
} 


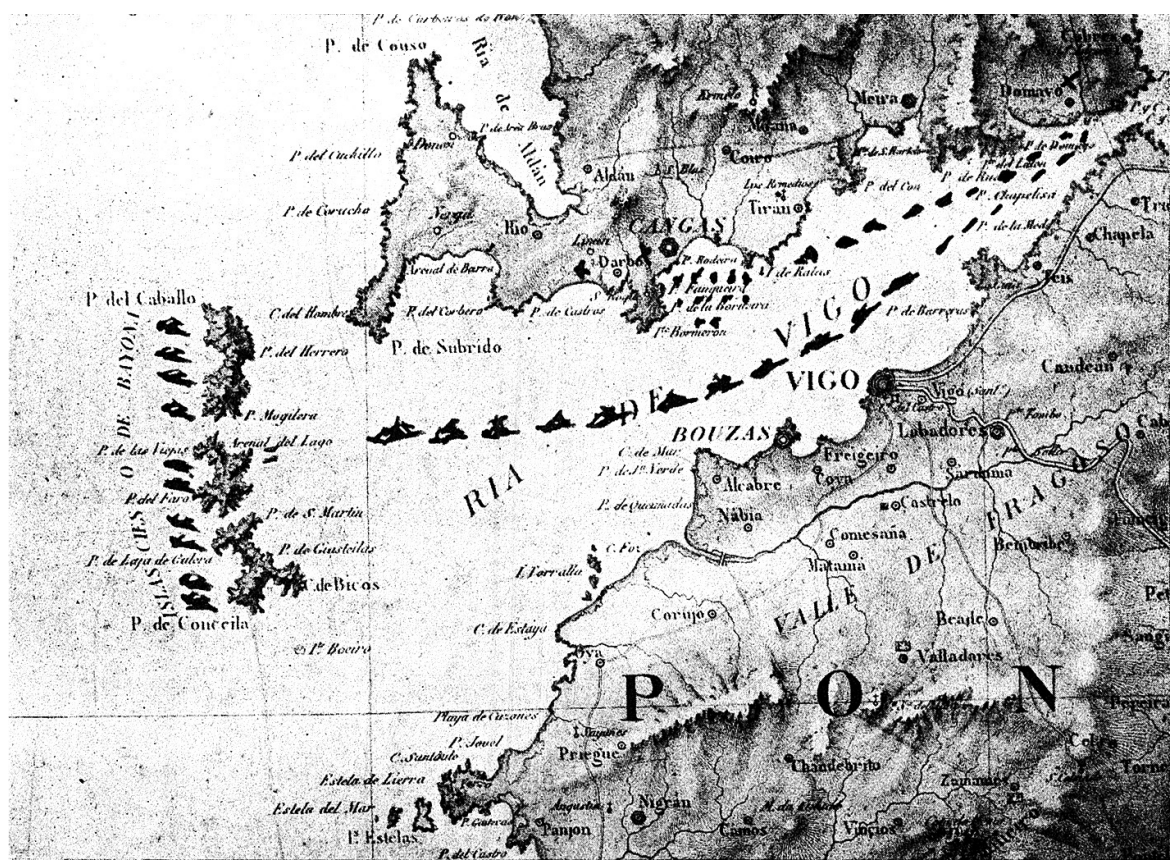

Fig. 2. Ruta del ataque de la escuadra turca a Cangas (1617). Fuente: Jesús CARro, "Entrada de los turcos en la villa de Cangas. Año 1617", Cuadernos de Estudios Gallegos, vol. XV, fasc. XV (1950), págs. 426-427.

villa fue enorme, y el de la violencia ejercida sobre sus habitantes aterradora. En la información que posteriormente se redactó sobre lo ocurrido, el procurador Gerónimo Núñez (que debe ser también el capitán del mismo nombre) señaló que los turco-berberiscos dejaron en Cangas más de cien muertos y más de doscientos cautivos $^{63}$, pero el detallado memorial adjunto en el que se consignan los nombres y apellidos de cada uno de los fallecidos y capturados contradice esta cifra y la reduce a 36 muertos y 80 cautivos, objetivo principal de los corsarios tras el pillaje ${ }^{64}$.

La descarnada descripción de la causa de la muerte de aquellos que opusieron alguna resistencia o trataron de huir es estremecedora, como puede comprobarse

\footnotetext{
${ }^{63}$...y an muerto más de cien perssonas con muchas heridas y cuchilladas que le an dado, y cautivado otros más de ducientas perssonas hombres y mugeres y niños. "Información sobre la entrada de los turcos..." (declaración de Gerónimo Núñez).

64 Ibidem (Memorial de las personas que se an muerto y cautibado en la villa de Cangas). La declaración de un renegado apresado disminuye aún más el número de muertos y prisioneros: ...cautibaron 36 hombres, 20 mugeres y 7 niños y niñas [63 en total] y mataron diez o doze personas, y murieron seis moros. Carta del Marqués de Cerralbo a Felipe III, 1617, diciembre, 17.- Coruña. AGS.-GA., leg. 822, en M. C. SAaVedra VÁzQuez, Actividad militar..., pág. 345, nota 128.
} 
en los ejemplos que siguen. Al ser enterradas, las víctimas mostraban en sus cuerpos, las heridas e cuchilladas, recibidas:

El capitán Pedro Costas Franco le mataron con un mosquetasso
y dos cuchilladas una en la garganta e otra en el rostro; Domingo
Pérez Hurtado, alférez de la compañia del capitán Pedro Vermú-
dez de Sotomayor, le mataron con tres cuchilladas las dos en la
caveza y otra en la garganta; Juan de Refojos, familiar del Santo
Oficio, le mataron de un balaso en los pechos y dos cuchilladas,
una en el rostro y otra en la caveza; (...) Catalina Núñez, biuda, le
mataron con tres cuchilladas de las quales le cortaron una pierna
e un brasso; Margarida Solla, biuda, le cortaron un brasso y le
dieron una cuchillada en la garganta de que murió; (...) Gonzalo
de Miranda, alguacil, le mataron de tres cuchilladas, las dos en la
caveza y otra en la garganta; Ylbira de Fuentefrí, muger de Juan
Breton, le mataron de tres cuchilladas, la una en la garganta, con
la cual la degollaron, y le cortaron una mano, y otra en una pier-
na; (...) Domingos Fernandez, el mozo, le mataron cortándole las
piernas; Fernando de San Pedro le mataron de un flechasso y dos
heridas, una en la garganta e otra en la cabeça; (...) Costança de
Lemos le mataron con cinco heridas, la una en la caveça y las dos
en entrambos pechos quitandole las tetas del pecho, y las demás en
su mesmo cuerpo; (...) María de Riomao, muger que fincó de Juan
Freire, le mataron con dos heridas y le quitaron la lengua y ojos ${ }^{65}$.

La terrible desgracia padecida avivó en los vecinos el deseo de buscar culpables entre los que habían tenido en sus manos la responsabilidad de la defensa, dirigiendo su rencor especialmente contra el sargento mayor. El domingo por la noche, después de haber puesto a resguardo la cruz de la iglesia de Cangas, y acompañado por San Juan de Romay, racionero de la Colegiata, el oficial se acercó a la villa -libre ya de corsarios-donde vieron que todavía estaba ardiendo una casa frente a la iglesia. Parecía que todo había vuelto la calma, pero en la mañana del lunes día 11, el sargento mayor se encontró con la ira del vecindario, quizás convenientemente azuzada por los mismos con los que anteriormente había estado enfrentado:

...se lebantó toda la villa contra mí, entre los quales heran los siguientes; Graviel (sic) de Noguera, mercader, y un hermano suyo

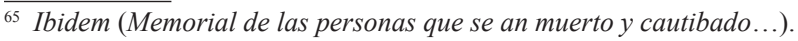


que se dize Francisco de Oitavén, procurador de causas, y otro hermano suyo, y Simón Fernandez, errero, y Juan Dobal, cabo de esquadra, y Diego Dorado, sargento, y otros muchos más con palos, piedras y espadas desnudas tirándome de cuchilladas y pedradas, y alçando los palos para executar en mí su malizia y tratándome mal de palabras, diziendo que me avían de matar y me hiçieron apear de la cabalgadura en que yba, por fuerça me la quitaron y me echaron de la villa a pie y se me quedaron con la cabalgadura no siendo suya sino mía, de los quales tengo testigos de vista por donde se echan de ver la pasión y odio que me tienen, y todo a sido por ordenarles lo que comvenía en serviçio de Su Magestad y ellos no quererme obedecer ${ }^{66}$.

Dos meses después del ataque, en 7 de febrero de 1618, el concejo de Cangas pidió a la cabeza de su provincia que en atención a sus muchos muertos y cautivos y a la ruina y pobreza en que había quedado, se la aliviase del impuesto de la sisa, y que le prestase su favor para que asímismo S.M. le hiciese merced en las alcabalas y demás tributos que en la villa se pagaban, para que se buelba a restaurar, pues, no le a quedado caudal, para azello ${ }^{67}$.

Según exponía Gerónimo Núñez en su informe posterior al ataque, la villa de Cangas,

era de las prencipales del Reino, de más de quatrocientos vecinos, y muchos dellos personas ricas, quedó perdida asolada y despoblada y la gente que a quedado tan pobre y necesitada que no les a quedado un vestido que echar sobre si ellos ni su mugeres y familia, ni otra cossa de que balerse, en que Su Magestad a perdido de alcabalas, sissas, sal, servicio hordinario, bulas y otros tributos que se le pagan, más de setenta mill reales cada un año.

Tomando como base los 400 vecinos que se citan (en torno a unos 1.500 habitantes aproximadamente) la población habría perdido entonces algo menos de un $8 \%$ de sus efectivos entre muertos y cautivos. Núñez pedía que S.M. fuese informado y en consecuencia, que amparase la dicha villa y se fortificase el puerto:

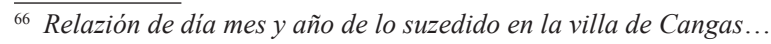

${ }^{67}$ Información sobre la entrada de los turcos...". 
...y hazelle merced para que se buelba a restaurar porque no se acave de despoblar, y que de aqui adelante tenga reparo para su defensa contra el henemigo, que no solo será caussa para que se restaure la dicha villa pero eso mesmo para que los nabios que se acogieren al dicho puerto hestén seguros de los dichos henemigos,...68.

Cuando dieron por concluida su violenta correría por el Morrazo, los corsarios se reembarcaron en su escuadra cargados con su botín y con sus presas y animados por el éxito obtenido se dispusieron a poner proa hacia Vigo para intentar realizar otro asalto. Sin embargo, para alivio momentáneo de sus atribulados vecinos, los navíos se vieron obligados a permanecer fondeados algunos días en el mismo surgidero con motivo del fuerte temporal que sobrevino ${ }^{69}$.

No obstante, la escuadra enemiga no cejó de insistir en su tenaz propósito de caer sobre la costa sur de la ría, y en cuanto tuvo oportunidad se hizo a la vela en dirección a Bouzas, yendo a situarse ante la feligresía de San Miguel de Oia.

Una vez posicionados los navíos frente a la costa, los corsarios hicieron demostración de querer acometer por esta parte y realizar un desembarco. Con el fin de impedirlo, don Pedro de Guevara ordenó que acudiera inmediatamente la compañía del capitán don Gregorio Vázquez Ozores, que fue apoyada por mucha otra gente armada de Vigo y otros lugares. Igualmente, don Diego de Grijalba ordenó al capitán don Álvaro Pérez de Ceta que volviese con su compañía al puesto que se le señalaría en San Miguel de Oia, desde donde acudiría a la parte donde fuera más necesario ${ }^{70}$.

Antes de estos hechos, al producirse la llegada de los musulmanes a la ría, don Diego de Grijalba, desde Baiona, había dado aviso del suceso al Capitán General, notificándole la presencia de once embarcaciones que anteriormente ya habían recalado en las Cíes (lo que demuestra que el ataque era premeditado), y la captura por ellas de dos lanchas de pescadores. También don Pedro de Guevara había notificado desde Vigo al Capitán General que dichas embarcaciones hicieran su entrada en la ría disparando su artillería con la pretensión de forzar un desembarco. Añadía que aunque había conseguido rechazarlos con las fuerzas a sus órdenes, necesitaba que le enviase municiones y gente armada. El Marqués de Cerralbo, que a su vez informó al rey, respondió a Guevara que le

\footnotetext{
${ }_{68}$ Ibidem (declaración de Gerónimo Núñez; en similares términos se expresa también el canónigo Álvaro de Aballe).

${ }^{69}$ Doc. de la Casa de Pajarín, en C. VÁzQuez Marinelli et al., Historia de Cangas, pág. 297; N. TABOADA LEAL, Descripción topográfico-histórica..., pág. 193.

70 “Certificación del Concejo de la villa de Bouzas...” N. Taboada y Leal, Ibidem, pág. 195; F. Avila y LA Cueva, Historia civil y eclesiástica..., fol. 400.
} 
mandaba un refuerzo de 20 mosqueteros y arcabuceros bajo el mando del alférez Bernardino Bravo ${ }^{71}$.

Por entonces, el Capitán General también recibió aviso del cabo de las milicias del partido de Pontevedra, Payo de Montenegro, diciendo que los navíos corsarios tomaban rumbo a Cangas - un lugar abierto-, pero que no podía resistir, y que los corsarios, tras desembarcar con quince lanchas, habían quemado el lugar. En estas circunstancias, Montenegro decía que había decidido volver a Pontevedra, por hallarse esta villa sin munición, sin mando y sin gente adiestrada para defenderla. El Capitán General le contestó que le enviaba tropas y municiones con el capitán Alonso Mateos Rondón y los alféreces Juan Serrano y Rodrigo Vázquez, así como una orden al alférez Bernardino Bravo para que se quedase con su tropa en Pontevedra, dejando a criterio del capitán Rondón el socorrer a Cangas con las fuerzas que no necesitase para la defensa de Pontevedra. El Marqués de Cerralbo, en carta al monarca, se dolía de los muchos lugares que el Reino de Galicia tenía desguarnecidos y sin defensa, y de que lo único que se podía hacer era enviar gente del interior a las zonas marítimas, lo cual en cualquier caso proporcionaba una defensa muy débil, porque no eran tropas adiestradas y tampoco había escuadra, ni fortificación ni murallas en tierra ${ }^{72}$.

Cuando la escuadra musulmana cruzó desde Cangas hacia Vigo y Baiona en un renovado intento de forzar un desembarco, los corsarios trataron de infiltrar a dos renegados cristianos, y acercándose con sus navíos, desembarcaron de ellos cerca del pueblo dos espías que vinieran a Vigo a tomar informes si había o no mucha gente para dirigirse con exactitud. Pero este plan quedó frustrado cuando ambos fueron capturados en el camino, reconociéndose su condición de renegados.

Obligados a confesar, se les tomó declaración ante don Pedro de Guevara, dando fe de ello el notario Ozores, vecino de Santo Tomé de Freixeiro, en 11 de diciembre de 1617. De dicha declaración constó que uno se llamaba Domingo Martínez, quien fuera vecino de la parroquia de San Juan de Tirán (contigua a Moaña), apellidado también Juanico, hijo de Juan Blanco y Susana Martínez, alias Jatata, el cual foi carreado por el moro; el otro era Cristóbal Meléndez, moro de los del reino de Argel $^{73}$.

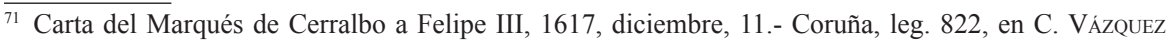
Marinelli et al., Historia de Cangas, pág. 299.

72 Ibidem.

73 Doc. de la Casa de Pajarín, en C. VẢzquez Marinelli et al., Historia de Cangas, pág. 297. Cita también el nombre de estos renegados F. Avila y La Cueva, Historia civil y eclesiástica..., fol. 399. Era frecuente que antes de un ataque desembarcasen unos pocos renegados que conocían el idioma y no despertaban sospechas entre la población para recoger información y determinar las posibilidades de éxito.
} 
Domingo Martínez confesó que tanto él como Cristóbal Meléndez servían en la nave Almiranta musulmana, y que su escuadra venía bajo el amparo del Rey de Argel,

con intención de robar, quemar y cautivar las gentes del Reino de Galicia, y que particularmente habian oído al Almirante Carlete (sic) habian de entrar en Bouzas, Puertonuevo, Marín y Bueu, por ser plaza fácil de robar, así como igualmente los navios que se hallaren.

Para este efecto, habían salido juntos del puerto corsario norteafricano 26 barcos que se habían separado a la altura del cabo de San Vicente en dos escuadras, formadas por 12 y 14 navíos respectivamente. La primera, al mando del citado Almirante Carlete, se mantenía en alta mar y pronto vendrían a juntarse en las Islas de Baiona con los que estaban anclados en la Ría, al mando del Almirante Pedro, turco de nación, pues que su situación era darle la mitad de lo que robasen al rey de Argel para que de ellos pagasen a los soldados, y la otra mitad partir entre los Almirantes, pilotos, etc. ${ }^{74}$

Se supo además que había también un renegado de la parroquia de Darbo, llamado Pedro Guerra, y otro de Cangas, apellidado Cadabón, quienes habían tratado con el tal Almirante Pedro, que viniese a Bayona y Vigo a saber la gente y armas que había, como también navios de Brasil, y otros ${ }^{75}$.

A este respecto, don Pedro de Guevara escribió al Capitán General noticiándole de la captura de un segundo espía, cuyos padres eran moriscos expulsados del reino de Granada, el cual llevaba 12 años, con los turcos, en Argel, refiriéndose seguramente al citado Cristóbal Meléndez. Este espía confesó acerca del número de navíos corsarios y su armamento y sobre el ataque perpetrado contra Cangas, repitiendo que su intención era entrar en Vigo y otros puertos carentes de protección:

...dize que traen 14 baxeles y que los onze estan en la ría de Vigo y los tres andan por la mar para dar aviso, y que traen dos mill hombres y veinte renegados portugueses y castellanos, y la capitana

\footnotetext{
$\overline{74}$ Doc. de la Casa de Pajarín, en C. VÁzquez Marinelli et al., Historia de Cangas, pág. 298. Según la Relazión del sargento mayor de Cangas, los catorce navios de turcos, heran de la conserva de treinta y ocho que avían salido de Arjel. Relazión de día mes y año de lo suzedido en la villa de Cangas...

75 Doc. de la Casa de Pajarín, ibidem. En este documento se nombra a otro renegado más, llamado Gerónimo Felú, vecino de Pontevedra. La transcripción de la copia del documento original es muy confusa, y según los autores de la Historia de Cangas el texto está interpolado con añadidos que lejos de aclarar su contenido contribuyen a dificultar su lectura.
} 
trae veinte piezas de artillería y todos los otros baxeles a doze, veinte mosquetes cada uno y los demás flechas y alfanjes, que en Cangas cautibaron 36 hombres, 20 mugeres y 7 niños y niñas y mataron diez o doze personas, y murieron seis moros, dize más que que el intento que tienen es entrar en Vigo y en los demás puertos abiertos y saquear y cautibar, lo qual dize que hizieron en un lugar de la Terceras [Azores] de donde sacaron doscientos cautivos..., y que el trigo que roban lo venden a franceses en Berbería... ${ }^{76}$.

El Marqués de Cerralbo estaba sin duda satisfecho de todo lo procedido por por Guevara (quien calificaba lo ocurrido en Cangas como, vergonçosa cosa para los que lo tenían a su cargo), pues finalizaba la carta en la que informaba al rey solicitándole que, honrre e faga merced a Pedro de Guevara ${ }^{77}$.

Al ver la fuerte movilización de gente armada que se desplegaba en la orilla, en la parte de San Miguel de Oia, dispuesta a ofrecer una firme resistencia, los corsarios se convencieron de que tenían pocas posibilidades de éxito, por lo que decidieron abandonar el intento y volver a su escuadra.

Pero al mismo tiempo empezó a entrar en la ría un barco procedente del Brasil cargado de azúcar y otras mercancías, el cual, al pasar ante la Armada enemiga, fue recibido con muchos tiros de artillería, saliendo a abordarla dos lanchas corsarias. Al observarlo desde tierra, don Pedro de Guevara mandó que fueran a socorrer la nave, enviando una barca con hombres armados para defenderla. Éstos consiguieron subir a bordo y protegerla, logrando que la nave continuara segura su ruta, retirándose hasta el puerto de Cedeira en Redondela, donde pudo resguardarse. Según se supo después por personas de la misma embarcación, importaba su carga más de 50.000 ducados ${ }^{78}$.

No pudiendo alcanzar su objetivo, y pareciéndoles que había muchas gentes en Vigo, el enemigo se hizo a la vela y se fue de la ría, internándose mar adentro, quedando las gentes sumamente alegres ${ }^{79}$.

Como los corsarios musulmanes entraran en la ría el día 7 , víspera de la

\footnotetext{
${ }^{76}$ Carta del Marqués de Cerralbo a Felipe III, 1617, diciembre, 17.- Coruña. AGS-GA, leg. 822, en M. C. SaAvedra Vázquez, Actividad militar..., pág. 345, nota 128; también en C. VÁzQuez Marinelli et al., Historia de Cangas, pág. 300. El doc. de la Casa de Paxarin (Ibidem, pág. 298) añade que la nave Almiranta traía 13 piezas de artillería y que a bordo de cada navío iban 130 hombres.

${ }_{77}$ Carta del Marqués de Cerralbo a Felipe III, en C. VÁzquez Marinelli et al., Historia de Cangas, pág. 300 .

${ }^{78}$ N. Taboada y Leal, Descripción topográfico-histórica..., pág. 195; F. Avila y La Cueva, Historia civil y eclesiástica..., fols. 400-401.

${ }^{79}$ Doc. de la Casa de Pajarín, en C. VÁzquez Marinelli et al., Historia de Cangas, pág. 297.
} 
Purísima Concepción, el obispo de Tui dispuso que en adelante, en tal día se ayunara en su obispado en razón de liberar del cautiverio a los que habían sido capturados. Los vecinos de Vigo hicieron voto de guardar todos los años dicho ayuno, absteniéndose de comer carne, y se comprometieron a iluminar las casas en honor a la Purísima la víspera por la noche, celebrando al día siguiente solemne festividad con procesión por las calles ${ }^{80}$.

La noticia del ataque a la villa de Cangas llegó a Santiago el domingo 10 de diciembre. Desde esta ciudad, el obispo auxiliar, don Fernando de Vera (que gobernaba la archidiócesis en nombre de su tío, el Arzobispo don Juan Beltrán de Guevara) se dirigió inmediatamente a Pontevedra en prevención de que esta villa pudiera sufrir un ataque y contribuir así a su defensa. El obispo partió llevando consigo cien hombres de Santiago y Padrón, acompañado por don Rodrigo de Moscoso, algunos caballeros y otros ciento cincuenta hombres vasallos de la Casa de Altamira, entrando en Pontevedra el lunes 11 al amanecer $^{81}$. El 15 de diciembre el Cabildo compostelano despachó un correo al citado obispo para tratar del rescate de los cautivos, y con el mismo objeto se acordó escribir al día siguiente al Arzobispo y al Gobernador del Reino, Marqués de Cerralbo ${ }^{82}$.

El 19 de diciembre, al día siguiente de haberse hecho a la vela los corsarios, el Capitán General decidió recorrer todos los puertos atlánticos para inspeccionar sus defensas y alarmas. Tres semanas más tarde, el 9 de enero de 1618, el Concejo de Pontevedra dio aviso al de Cangas de su próxima llegada, visitando la desgraciada villa diez días después ${ }^{83}$.

En Galicia fueron plenamente conscientes de lo que suponía la inesperada llegada de los corsarios musulmanes al litoral Atlántico y su recientemente adquirida capacidad para surcar los mares en las condiciones más adversas. Las amargas palabras contenidas en la carta que el Cabildo compostelano dirigió a su arzobispo con motivo del ataque resultaron desgraciadamente proféticas al solicitarle que regresara a Santiago,

para serbirse de proveer y socorrer, no sólo para el rescate de tantos vasallos como le lleban a V. Y. captivos a Argel, sino también para supplicar a Su Magestad mande guarnezer estos Puertos Maritimos,

\footnotetext{
80 Ibidem; F. Ávila y La Cueva, fols. 401-402. Leg. 2633, fol. 86.

81 Jesús CARro, "Entrada de los turcos en la villa de Cangas. Año 1617”, Cuadernos de Estudios Gallegos, vol. V, fasc. XV (1950), págs. 426-427.

82 A. López Ferreiro, Historia de la Santa..., págs. 47-48.

83 C. VÁzQuez Marinelli et al., Historia de Cangas, pág. 304.
} 
de que son tan señores estos turcos y moros que en ellos están surtidos, que no ay cosa que los offenda por la mar. Y lo que es peor, en agora que los turcos saben el camino tam bién que se atreben a pasar el Estrecho en el rigor del hibierno con nabios tan grandes y de alto borde como traen, podemos verisímilmente creer que para la primavera y cada día nos causarán mayores daños ${ }^{84}$.

En las jornadas que se sucedieron el peligro seguía latente, pues a finales de diciembre las embarcaciones que habían asaltado Cangas, unidas a otras muchas que formaban una gran escuadra de 60 naves, recorrían todavía las costas gallegas, quemando algunos puertos y tomando gran cantidad de cautivos ${ }^{85}$, como ocurrió en Malpica. En esta villa desembarcaron, los turcos el año de diez y siete, saqueando y quemando el luguar, corriendo la tierra, donde cautivaron mucha gente y tomaron mucho ganado sin que nadie se lo estorvara ${ }^{86}$. Después llegaron a amenazar Viveiro, que se preparó para la defensa llamando a las armas a todos los vecinos de la villa y de las feligresías circundantes:

...y luego que a todos les sea notificado lo susodicho haréis que otro día sigiente se junten todos con sus armas delante de nuestras casas, y alli juntos los recontaréis los arcabuzes, picas y otras harmas que ai y tienen y quantos son los soldados, y todos juntos los habisareis como cada día se aguarda en esta billa al enemigo, el cual está en este Reino de Galiçia sesenta nabios de moriscos turcos y otros enemigos los quales an enpezado a quemar algunos puertos deste reino y cautibar mucha jente y se tiene por cierto que bendrán ha esta billa y su contorno, y ansi hes nezesario que estén prebenidos con sus harmas a dar el fabor y socorro a esta billa $u$ otra parte donde se les fuere mandado... ${ }^{87}$.

\footnotetext{
$\overline{84}$ Carta del Cabildo al Arzobispo don Juan Beltrán de Guevara, [1618, enero, 17.- Santiago], ACS, Minutario de cartas y exposiciones (1610-1617), fols. 132v.-133r., en J. CARro, "Entrada de los turcos..., págs. 426-427

85 A finales de diciembre de 1617, don Francisco Ortega Davila, señor de San Esteban de Silán (parroquia del Concejo de Muras-Lugo), mandó que los vasallos de dicha jurisdicción se juntaran con sus armas para socorrer a la villa de Viveiro, amenazada por una escuadra de sesenta navíos, tripulada por turcos, moriscos y otros enemigos. Colección de documentos históricos..., vol. II, 1931, págs. 146-147.

${ }^{86}$ Pedro TeiXeira, "Descripción de España y de las costas y puertos de sus reinos", fols. 35r.-v., en Felipe Pereda y Fernando Marías (eds.), El Atlas del Rey Planeta (1634), Hondarribia, Editorial Nerea, 2002, pág. 328. El autor compuso el Atlas de 1622 a 1634 y estuvo en Galicia en 1622.

87 Colección de documentos históricos..., vol. II, 1931, págs. 146-147.
} 
Para tratar de aliviar un poco la situación de la villa de Cangas y recuperar el culto, en enero de 1618 el Cabildo compostelano donó a su Colegiata un terno, un cáliz y veinte ducados para la ropa blanca de la iglesia. Meses después, el 19 de octubre, en vista de una carta de Domingos Prego de Montaos, capitán de la compañía de Cangas, que estaba cautivo en Argel, se enviaron cien ducados para su rescate ${ }^{88}$.

A mediados de febrero de 1619 llegaron a Cangas los frailes de la Orden de la Merced. Pero siendo tantos los cautivos de Cangas sólo unas pocas familias pudieron ofrecer alguna cantidad como ayuda para que fueran redimidos ${ }^{89}$.

A lo largo de los años siguió el goteo incesante de rescates con la consabida sangría de dineros cristianos que pasaban a engrosar las arcas corsarias ${ }^{90}$. Además de las cantidades ofrecidas en mandas y testamentos con destino a la redención de cautivos, los familiares podían obtener a veces otras ayudas y facilidades que les permitían conseguir el dinero necesario; caso de licencias para pedir limosna en la diócesis o en otros obispados ${ }^{91}$. La redención del cautivo podía demorarse durante años ${ }^{92}$ y el regreso no siempre era posible a causa de su muerte o por no

\footnotetext{
88 A. López Ferreiro, Historia de la Santa..., pág. 48.

${ }^{89}$ María de Outeiro entregó 60 ducados castellanos para el recate de su marido, Pedro Garrido, cautivo junto a sus dos hijos, Gregorio y Juan; Dominga Bernárdez y su hijo Juan Bernárdez entregaron 30 ducados para el rescate de Antonio do Souto, su marido y padre; Teresa Bernáldez se comprometió a entregar a la Orden Mercedaria 300 reales (27 ducados) una vez liberado su marido, el zapatero Gregorio Pérez; Ana Álvarez, mujer de Domingo de Orceira, manifestó el mismo compromiso en 200 reales; igualmente, los hermanos Domingo, Andrés y Bastián, se comprometieron también a entregar 20 ducados para ayuda del rescate de su madre, Sancha Mourisca. Por su parte, María Martínez, viuda, hubo de pedir prestados 200 reales a Juan Gallego como ayuda para la liberación de su hijo, Sebastián de Santa Marta. También se consiguió la redención de Domingo Martínez, de Darbo, y de dos hijos de Francisco de Marcos. C. VÁzquez Marinelu et al., Historia de Cangas, págs. 308-309. Igualmente, se pidió rescate por el escribano Juan da Veiga (ibidem, pág. 303), quien otorgó testamento en 15 de junio de 1618, hallándose cautivo en la Ciudad de Argel, y entre los testigos que en él pone, que son muchos, nombra á algunos que eran naturales del mismo Cangas y alli estaban con el testador, que sin duda todos ellos fueron hechos cautivos en la presente invasión del Turco. F. Avila y LA CuEva, Historia civil y eclesiástica..., fol. 402.

${ }^{90}$ Los frailes de la Merced visitaban los mercados esclavistas anualmente trayendo noticias de los cautivos a sus familiares, quienes una vez conseguido el dinero necesario para el rescate lo entregaban a los frailes intermediarios. Para facilitar su labor, en las escrituras de obligación se especificaba con detalle las características físicas del cautivo a redimir, incluyendo defectos, color de pelo y ojos, lunares u otros detalles identificativos (Véase la nota 121). En C. VÁzquez Marinelli et al., Historia de Cangas, pág. 307, se cita también un doc. del AHPPo., prot. 1147, fol. 34, año 1667.

${ }^{91}$ Para liberar a su marido, Ana Souto obtuvo permiso por escrito para pedir limosna en distintos obispados cerca de 8 años. En esa misma circunstancia se vio Ignacio Fernández, vecino de Pontevedra a quien los obispos de Lugo y Orense otorgaron escritura que le permitía recaudar limosnas para redimir a su hijo Bartolomé, cautivo en Argel. C. VÁzquez Marinelli et al., Historia de Cangas, pág. 307 (cita AHPPo, Escribano Antonio Díaz de Castro, 18 de febrero de 1701).

${ }_{92}$ En el testamento de un tal Juan Soliño se dice que estuvo cautivo, por más de quince años en la ciudad de Argel (...) y fue liberado gracias al pago de doscientos ducados. Otro testamento, de 1671, de Portonovo, expresa: Dejo por heredera universal a mi hermana Antonia Domínguez, que está cautiva en Argel,
} 


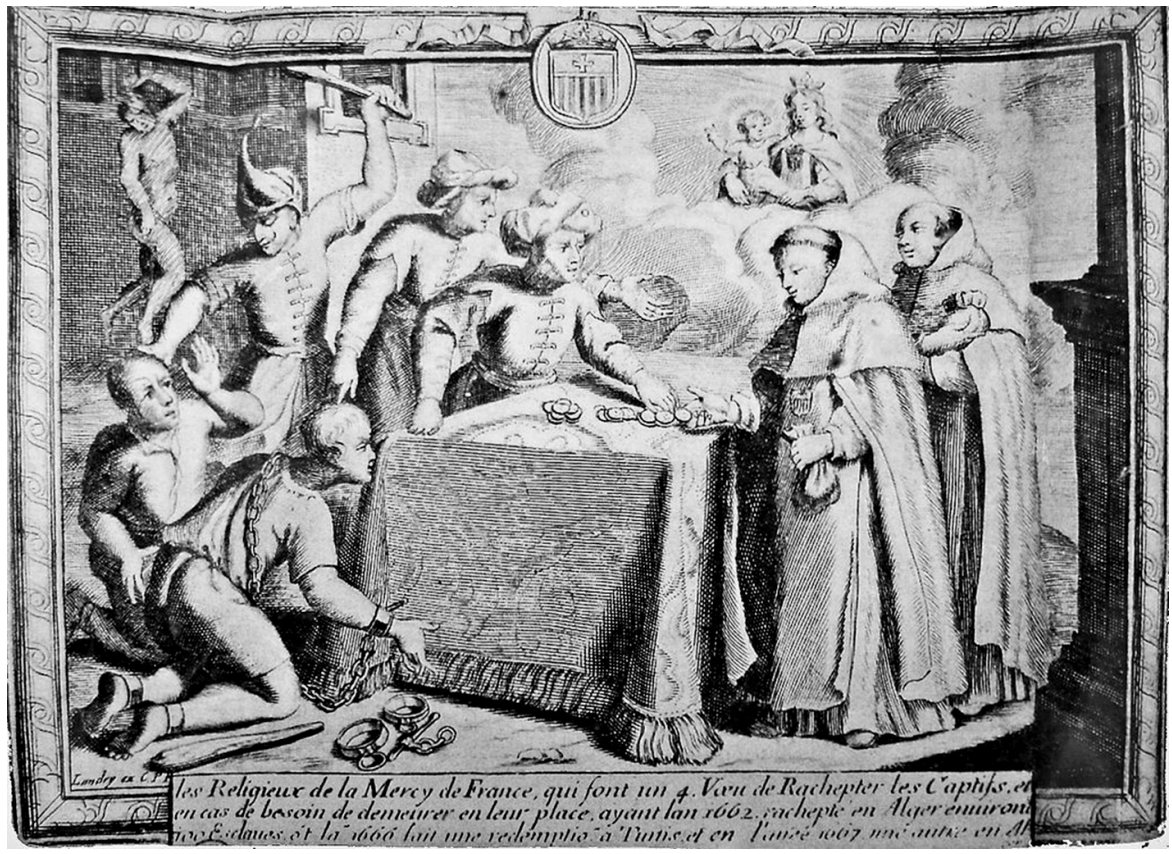

Fig. 3. Grabado de época que representa un rescate de cautivos por frailes de la Orden de la Merced.

ser factible su rescate por alguna razón, dejando a sus seres queridos sin esperanzas de recuperarlo ${ }^{93}$.

Casi dos años después del asalto a Cangas, en carta datada el 15 de noviembre de 1619, el rey escribió al Cabildo catedralicio compostelano por intermedio del Marqués de Cerralbo, solicitando una ayuda económica para la habilitación de una escuadra que vigilase las costas gallegas y las defendiese de los turcos y

para que los tenga y sean suyos, y si en este interin que no se rescate y no viniere a esta villa (...), dentro de doce años mi hermana Antonia, pueda venderse la casa y más bienes que se hallaren. En C. VÁzQUEZ Marinelli et al., Historia de Cangas, pág. 310 (cita AHPPo, prot. 1147, fol. 34, año 1667 y prot. 1669 y 1660, año 1671).

93 Muchos años después del ataque, en 1651, se señalaba en el libro de fábrica de la Colegiata de Cangas que el prior y el racionero tenían 130 reales destinados al rescate de un prisionero, que no tuvo efecto por haberse muerto, aplicándose a la construcción del coro. En realidad el dinero estaba en manos del escribano Juan de Oitabén. C. VÁzQuez Marinelli et al., Historia de Cangas, pág. 310 (cita Archivo Parroquial de Cangas, Libro F. 1, año 1651). En ese mismo año, un padre declaraba haber pagado por su hijo de 15 años, 1.200 reales para quitarlo del cautiverio de Argel, lo cual tengo noticias ciertas que se murió habrá quince años sin dejar hijos ni descendiente alguno. Ibidem (cita AHPPo, prot. 1085, 28 de julio de 1651). 
otros enemigos, que continuaban asaltándolas y robándolas. El Cabildo concedió entonces 500 ducados anuales pagaderos durante cuatro años ${ }^{94}$.

Víctimas a posteriori de este ataque fueron varias mujeres de Cangas acusadas de brujería, siendo la más conocida María de Solina o Soliña, viuda y hermana de los pescadores Pedro Barba y Antón Soliño. Ambos murieron en la fracasada refriega que se produjo en San Pedro de Domayo frente a los argelinos, a resultas de la que también se llevaron cautivo a su sobrino, Pedro Martínez. Con su casa quemada, y seguramente muy trastornada por el sufrimiento y la miseria y a causa de oscuros intereses, María Soliña fue acusada cuatro años después por la justicia seglar de Cangas de haberse comportado como una bruja, por lo que recibió tormento. Remitido su caso al Santo Oficio de la Inquisición de Santiago, y previa confesión de la mujer, el tribunal acabó votando que fuera reconciliada, en forma y confiscación de bienes, que no se hallaron por ser muy pobre. Finalmente fue sentenciada a llevar el hábito penitencial tan solo por medio año ${ }^{95}$.

\section{SIEMPRE ESTÁN CON LAS ARMAS EN LA MANO.}

\section{LA PERSISTENCIA DEL CORSO BERBERISCO}

La orografía recortada del litoral gallego y las pequeñas islas muy próximas a tierra favorecían la sorpresa y servían de excelente refugio y escondite a los corsarios. El cosmógrafo Pedro Texeira, en su "Descripción de España y de las costas y puertos de sus reinos", hacía constar que las islas Sisargas, frente a Malpica,
Despobladas, solian de la tierra y sus lugares pasar mucho ganado a ellas. Y después que este mar se a enmundado con los turcos y piratas, bienen a estas yslas a dar fondo muy de ordinario en una cala que tiene de la parte del sur en seis y siete y ocho braças ${ }^{96}$.

\footnotetext{
${ }_{94}$ A. López Ferreiro, Historia de la Santa..., págs. 48-49; E. Fernández Villamil, La Escuadra de Galicia..., pág. 18.

95 Véase el documentado trabajo de Manuel Rodal GonzÁLEz, “Afán de la justicia seglar por mostrar brujas en la villa de Cangas”, Pontevedra. Revista de Estudios Provinciais, vols. 8-9 (1992), págs. 197-230, y el ya clásico de B. BARreiro, Brujos y Astrólogos de la Inquisición de Galicia, págs. 145-154 y 239-241. En este libro Barreiro opina sobre la antigüedad de ciertos versos hallados por José Ojea en un pergamino foral de Celanova, creyéndolos eco adulterado de alguna canción contemporánea sobre el ataque a Cangas (B. BARreiro, ibídem, pág. 173 y ss.). Según Fernández Villamil se trataría con toda probabilidad de una apócrifa invención moderna. E. FernÁndez Villamil, La Escuadra de Galicia ..., pág. 92, nota 31.

${ }^{96}$ P. Teixeira, "Descripción de España...”, fol. 35v., pág. 328; también en J. M. VÁzquez Luó, La Matrícula de Mar..., pág. 69.
} 
En la isla de Ons, en la ría de Pontevedra, la parte del poniente les permitía ocultarse, sin seren bistos de los de la tierra ${ }^{97}$. Tambo, una ysla alta que queda distante de Pontevedra dos leguas, era un lugar,

donde de ordinario a su reparo bienen baxeles de moros y otros piratas a dar fondo, obligados de los tenporales. Y se están ancorados en esta ysla tan seguros, así de los tienpos como de que los ofendan, como si fuera en uno de sus puertos en África ${ }^{98}$.

La isla de Sálvora, en la ría de Arousa, fue saqueada en 1637 por corsarios musulmanes, que se llevaron prisioneros a varios de sus habitantes, quedando luego desierta hasta bien entrado el siglo XIX ${ }^{99}$.

Sin embargo, las más célebres de entre todas ellas por sus inmejorables condiciones para el refugio de todo tipo de naves eran las ya citadas islas Cíes, en la embocadura de la ría de Vigo, la primera ría gallega desde el sur:

Tienen fuentes de linda agua por lo qual son tan frequentadas de los piratas, allando en ellas la comodidad que los que navegan an menester porque allan en estas yslas puerto segurísimo y de exçelente surgidero. Seguro de los tienpos azen livremente agua y leña y an conosido ser parage la destas yslas para aguardar las prezas que sin dificultad bienen a caer en sus manos de ordinario que, como ellas son tan altas, los que bienen de mar en fuera no pueden descubrir se ay navios en su puerto sino hia junto con ellos. Y ellos los descubren luego, demás que los que aqui están aguardando la presa tiene en tierra atalaia que los aviza qué navios bienen, y de qué parte y quantos, con que sienpre quedan con bentaja saliendo con las armas en la mano a resibirlos y, finalmente, ellas son una cueba de ladrones ${ }^{100}$.

Después del ataque a Cangas y a otros lugares de la costa gallega, los temidos corsarios musulmanes pronto regresaron a Galicia, realizando escala casi siempre

\footnotetext{
97 P. TeiXeira, “Descripción de España...”, fol. 40r., pág. 331.

98 P. Teixeira, ibidem, fol. 40r., pág. 332.

99 J. M. VÁzquez Lijó, La Matrícula de Mar..., pág. 69 y nota 78.

${ }^{100}$ P. Teixeira, "Descripción de España...", fol. 41r., pág. 332. La Junta del Reino de Galicia concedió en 1629 un donativo de 40.000 ducados para construir un fuerte en las islas de Baiona, por ser cossa de tanta ymportançia, que sin él no se puede conserbar el Reyno, por los muchos daños que de alli hacen los olandeses e yngleses Memorial de súplicas del Reino al Monarca, Actas de las Juntas del Reino de Galicia, vol. I, fol. 10r., Doc. 48-D, págs. 562-565.
} 
en las islas Cíes. Hay ya noticias de ellos en agosto de 1618 en el puerto de Cariño y por aguas cercanas a Coruña con cinco navíos y atacando naves mercantes, como así lo informa al Consejo de S.M. el licenciado Juan de Llerena y Moreda, Corregidor de la villa de Viveiro:

Çinco franceses an llegado oy a esta villa, y me an dicho que en el puerto de Cariño, que está cinco leguas de ella, le salieron a un navio que llebaban con mercaderías çinco navíos de moros que le dieron caça; y ellos, antes de llegar a las manos, conoçiéndolos y temiendo que los abían de cautibar, se uyeron en un batelillo que llebaban; y, aunque los siguieron los moros, no los alcançaron, y les cogieron el navio con las mercaderías y se lo llebaron; y lo mismo suçedió ará quinçe días con otra carabela de portugueses que salió cargada de madera desta villa, que çerca de la Coruña se la quitaron, y se escaparon los portugueses que iban en ella en otro batel; y es lástima que se atreban a lo que jamás suçedió, que es rondar moros los puertos de España y hacer mal en ellos, cautibando a los cristianos y robándolos... ${ }^{101}$.

De las palabras del Corregidor Llerena se infiere que la presencia de los corsarios turco-berberiscos en las aguas gallegas era un fenómeno reciente y probablemente poco anterior a 1617, cuando se produjo el asalto a la ría de Vigo (del que critica la negligencia de los responsables de defender Cangas). En su informe al Consejo, el Corregidor se lamentaba de que, en la práctica, no le fuera permitido encargarse de la defensa con la libertad que él desearía,

significando (...) la obligaçión que los Corregidores de Su Magestad tenemos de defender sus puertos, yéndonos en ello más que la vida $y$ hacienda, que es la honrra; $y$, aunque por derecho tenemos esta obligaçión, nos atan las manos por el Consejo de Guerra, de suerte que sus ministros tienen por gloria el deçir que los Corregidores de Su Magestad no emos de poder visitar las armas de nuestros súbditos, ni las atalaias y çentinelas, ni poner espías, ni reconoçer a los enemigos, ni saber qué gentes y armas ay para poder defender esta villa y puerto, y prebenir lo neçesario, ni meternos en cosa

\footnotetext{
${ }^{101}$ Informe al Consejo de S.M. por el licenciado Juan de Llerena y Moreda, Corregidor de Viveiro, acerca de incursiones de piratas moros, 1618, agosto, 22.- Viveiro, BNE, ms. 13.239, en Pedro LongÁs, "Piratas moros en Galicia (siglo XVII)", Al-Andalus. Revista de las Escuelas de Estudios Árabes de Madrid y Granada, vol. XVI, fasc. 1 (1951), págs. 215-217.
} 
ninguna perteneçiente a su defensa y a la guerra, de suerte que, en estos casos, e de bibir a çiegas y esperar otro suceso como el de Cangas, que por no gobernarse por justiçia los dias pasados, uyó el sargento maior y cabo con mill y quinientos soldados de aquella tierra, gallegos, y desampararon el lugar por sólo çiento y çinquenta morillos que bieron desembarcados; y fue causa que llebasen cautibos a las personas de aquel lugar y muy gruesas haçiendas que allaron en él $l^{102}$.

En los meses siguientes, los corsarios musulmanes siguieron rondando el litoral gallego, y en diciembre de 1618 Baiona vio con inquietud la llegada a su costa de catorce navíos turcos, constatándose, que cada día salen éstos y mucho más de Lisboa y de otras partes ${ }^{103}$.

Casi un año después, en septiembre de 1619, se registra otra vez la presencia de naves corsarias musulmanas frente a Baiona; dos de ellas permanecían ante su puerto el 6 de dicho mes ${ }^{104}$, y en los días que siguieron se informó que los turco-berberiscos estaban realizando incursiones en la costa ${ }^{105}$. El lunes 9 de septiembre saltaron a tierra ocho ó nueve moros, detrás de Nuestra Señora de la Çela (parroquia de Baredo, Baiona), donde se perdieron las galeaças,

y fueron corriendo por tierra hazia el monasterio de Oya tras las moças que iban a la leña, y teniendo uno dellos ya una devajo el alfange, se encomendó a Nuestra Señora de la Çela, y en el mismo punto se caió el moro en tierra, aora fuesse porque tropeçó o que milagrosamente caiesse, estubo caido en tierra mientras la moça tubo lugar de acogerse, de allí se fueron hazia Mougás y cautibaron un honbre que andaba cogiendo argaço, y se envarcaron sólo con él, porque la gente de la tierra iba acudiendo.

\footnotetext{
${ }^{102}$ Ibidem.

${ }^{103}$ Carta de Diego de Grijalba al Conde de Gondomar, 1618, diciembre, 11.- Bayona. Real Biblioteca. Correspondencia del Conde de Gondomar. Sig. II/ 2165.- doc. 160. Resúmenes en Catálogo de la Real Biblioteca, tomo XIII, Correspondencia del Conde de Gondomar, vols. I, II y III, Madrid, Patrimonio Nacional, 1999-2002. Don Diego Sarmiento de Acuña, Conde de Gondomar (1567-1626), famoso embajador español ante la Corte de Jacobo I de Inglaterra, ostentaba además los cargos de cabo del obispado de Tui y Gobernador de la fortaleza de Baiona. También fue nombrado consejero del Consejo de Estado y Guerra. ${ }^{104}$ Cartas al Conde de Gondomar de: Francisco de Barros Troncoso, 1619, septiembre, 6.- Bayona. Real Biblioteca, Sig. II/ 2115.- doc. 197.

${ }^{105}$ Cartas al Conde de Gondomar de Diego de Grijalba, 1619, septiembre, 11.- Baiona; de Diego de Acuña y Cordido, 1619, septiembre, 12.- Baiona; y del doctor Fernán Pérez de Aldao, 1619, septiembre, 12.Baiona. Real Biblioteca, Sig. II/ 2115.- docs., 198, 186 y 188.
} 
Ya en el mar, a bordo de su lancha, los corsarios consiguieron tomar un pequeño barco pero fueron perseguidos, aunque infructuosamente, por una pinaza* armada en la que iban soldados y paisanos:

y con viento fresco llegaron a tiro de mosquete della y a este tiempo quedó la pinaça en calma y se escapó la lancha al remo, fue muy grande desgracia faltar el viento, que de otra manera la cogieran sin duda; salió otra vez la pinaça y Álvaro Pérez de Çeta por cabo $y$ de noche se fue la buelta de Portugal, y de allí se vino por detrás de las Islas, y no alló rastro de las lanchas ni de navios, esto es lo que ahora ay de nuevo... ${ }^{106}$.

Los meses de octubre y noviembre de 1619 fueron especialmente críticos. Un día, entre las ocho y nueve de la mañana, aparecieron 12 navíos turco-berberiscos bien armados persiguiendo a las pinazas de Baiona. Las naves corsarias dieron fondo en las islas Cíes, permaneciendo en ellas haciendo aguada y reparándose, obligando a las milicias a movilizarse acantonandose en la villa. En la relación sobre los sucesos, dirigida por Francisco Barros Troncoso, sargento mayor de la plaza, al Conde de Gondomar, su superior y amigo, se inserta también el interesante testimonio de un cristiano evadido acerca de los navíos corsarios, que habían salido de Argel en número de 26 con la intención de saquear y cautivar en las costas gallegas y portuguesas:

A treçe deste [octubre?] apareçieron doçe navios a la punta del cabo de Silleiro de la madre de Dios de la Çela, entre las ocho y las nuebe de la mañana, viniendo delante las pinaças desta villa que se benían huyendo, y al tiempo pareçían nabios pequeños por estar lexos y a la buelta destas hislas de Bayona, y así como los bi benir y más çer que me pareçió heran de enemigos, despaché un propio al señor Don Antonio, que dentro de una hora acudió su merced a este lugar; lo mesmo a los capitanes del balle de Miñor por estar el cappitán Diego de Grijalva enfermo, y todos acudieron luego, y las compañias de miliçia desta villa recojidas; y en este ýnterin los dichos nabios çercaron las hislas y entraron en ellas, y a las quatro acabaron de dar fondo entre la de San Esteban y San Martín; y

\footnotetext{
${ }^{106}$ Carta del doctor Fernán Pérez de Aldao al Conde de Gondomar, 1619, septiembre, 12.- Bayona Real Biblioteca, Sig. II/ 2115.- doc. 188.

* Embarcación de vela y remo, con tres palos, larga, angosta, ligera y de popa cuadrada. 
luego, la noche siguiente se hechó de ver azían agua y davan carena. Luego, el señor Don Antonio el dicho día siguiente se partió al amaneçer a San Miguel de Hoya llevando consigo jente de miliçia desta villa que yo escoxí y nombré, y adonde asistió acudieron las demás compañias del balle de Miñor para que de alli favoreciese el señor Don Antonio adonde tentase el enemigo, el qual se detubo en las hislas todo el día siguiente, tras el que entró asta las díez de la noche que se fue que hera a catorçe deste sin que se echase de ver asta el amaneçer a los quinçe, y luego truxo la guardia de la Çela un cautivo el qual se determinó y salió con ello por milagro que hiço la madre de Dios con él, adonde aportó y se escapó, como bio se querían haçer a la bela se echó a nado él y otro conpañero, y este primero se entró en un nabio presa, de tal punto desbaratado de hárboles y belas cargado de trigo que ya lo tenían todo raso sin hárboles, que el enemigo quería quemar antes de su partida, permitió Nuestro Señor que este honbre así como entró dentro de dicho nabio desbaratado se bino un aguacero y escuridad y solo él cortó el cable por donde estava amarrado y coxió el timón, y como haçía tiempo en popa se bino a las peñas de la Çela; y con andar la mar muy alborotada y él muy descalabrado de las peñas, le salvó Dios sin quedar estropeado, el qual haçe la relaçión siguiente:

Que an salido de Argel 26 nabios de guerra de turcos, abrá tres meses poco más o menos, derechos a saquear y cautibar a Muros en este Reyno, y que más allá de Lisboa los 16 dellos se abian apartado y los otros 10 restantes que llegaron a estas hislas a 19 de setiembre, que fueron los que yo abisé a Vuestra Señoría con otras tres presas, y como se partieron de las hislas diçe este hombre yban a Muros a executar su boluntad, y que el tiempo no les dio lugar y que pasaron el cavo de Finisterra donde quemaron un lugar y cautibaron 26 personas tres o quatro leguas de la Coruña, y de alli se bolvieron y llegaron como digo a estas hislas, y diçe este hombre que binieron a haçer agua y a espalmar, como lo hizieron en ellas, y que es çierto ban derechos a Harjel ricos de presas que habian cojido y con 200 cautibos christianos y que la Capitana era de porte de 400 y 50 toneladas y 36 pieças de hartillería, las dos de bronçe, 250 turcos con algunos esclavos christianos más pa<ra> haçer las faenas, y que el capitán turco hera el que quemó la nave de la Yndia en otro biaje, que hera persona de balor, los demás nabios diçe son de a 400 toneladas y de 380 a 200 turcos cada una por lo menos, a 18 y 20 pieças, todos nabios muy lijeros, grandes beleros hechos en Flandes, que la escuadra de Portugal les avía 
dado caza y ni los avía alcançado, que en Harjel avía 78 nabios de guerra y que unos entraban y otros salian a desenbocar el Estrecho y que llegados estos luego saldrían otros = Lo mesmo que éste diçe el conpañero que se hechó a nado con el que el señor Don Antonio truxo de las hislas adonde lo alló desnudo al amaneçer el día que el enemigo se fue, como su merced abisará a Vuestra Señoría a que me remito en todo ${ }^{107}$.

En consecuencia, Baiona hubo de estar pendiente de su litoral, obligando a guarnecer todo el tramo de costa desde el monasterio de Santa María de Oia hasta San Miguel de Oia para evitar que los corsarios desembarcaran con sus lanchas. Además, los turco-berberiscos amenazaban a las naves portuguesas y acometían las pinazas de los pescadores que salían a faenar, por lo que el sargento mayor de Baiona había decidido armar varias de estas embarcaciones para protegerlos:

...todos estos dias e pasado arto trabajo con turcos y moros de noche $y$ de día y acudiendo a toda esta costa desdel monestero (sic) de Oya a San Migel de Oya, que ya son tan ordinarios y atrevidos que se atreben adonde no allan defensa a desenbarcar en cada peña y caleta que tan pláticos son = que tan amenuno (sic) bienen a estas yslas de Bayona y a la vista desta villa a cargar navíos de cristianos como purtugueses a Ginea y Santomé a cargar negros, y Dios lo remedie, quiso su Devina Magestad que desta bes no llebaro $<n>$ desta villa más de tres personas que cogeron en un sabero, ni se atreberán adelante con sus la $<n>$ chas acometer las pinaças de aqui que salen a pescar, las quales hiçe armar de mosquetes y arcabuces y chuços que a sido causa el defenderse de las la $<n>$ chas de los moros y escalabrado y muerto algunos moros, y los días pasados armé a dos pinaças con gente de la vera y algunos soldados que fueron a socorer otra que la abordaron dos lachas de moros junto a la Çela, y abéndose defendido y muerto algunos sin que de los nuestros muriese persona, sino algunos eridos que ya están buenos,

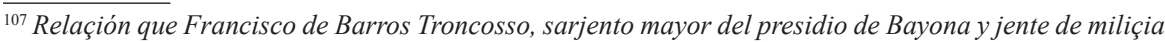
de sus contornos, haçe al señor Conde de Gondomar, del Qonsejo de Guerra de Su Magestad del turco que bino a las hislas de Bayona con diez nabios y del daño que hiço. Manuscrito [1619], Real Biblioteca, Sig. II/ 2225, fols. 61r.-62v. Publica una versión de este manuscrito, José SANTIAGo y Ulpiano Nogueira, Bayona antigua y moderna, Madrid, [s. n.] 1902, págs. 163-164. La insegura fecha conjetural del relato se basa en que en él se expresa que el capitán Grijalba estaba enfermo cuando sucedieron los hechos, y se sabe por otros documentos que estuvo convaleciente durante el mes de octubre, iniciándose su lenta mejoría a partir de noviembre.
} 
tuvieron por vien los moros uhise, llegaron las armadas y pensaron salían a pescar, las vino una lancha abordar y como llegaron tan çerca y vieron su mal no [...]daron uendo, y los nuestros le dieron descargas y le mataron sinco o seys, y por no poder alcançarlos se escapó la lancha. A seys días que no aparecen piratas, pero ellos bolberán presto... ${ }^{108}$.

Pero los corsarios eran astutos, y ahora que sabían que algunas pinazas iban armadas no se confiaban y no se dejaban capturar fácilmente, prefiriendo buscar objetivos más seguros:

...los moros y turcos tenemos cada día y nunca se les ha visto la cara aunque acuden al parage de las islas i a la vista de Bayona caçan algunos navios, de alli se sale a vezes so color de yr a pescar con pinaças armadas y no han hasta aora cogido ninguna lancha de moros que conocen el anzuelo y no quieren tocarlo y a otros acometen y cautivan. El General no sespanta desto ni por ello quiere que se moleste la gente acorralándolos en Vayona como se solía azer con navios olandeses, sólo manda que los de la vera de la mar acudan a resistir que no se desembarque, y aún de las compañias del Valle ha mandado que la de Gregorio Vázquez acuda a Vigo siendo llamada a su socorro, quiçá porquel capitán mora en aquella villa y no donde tiene la compañía ${ }^{109}$.

Finalizaba el mes de octubre y la amenaza corsaria continuaba. El sargento mayor de Baiona, envió otra relación de lo que estaba pasando en las costas gallegas al Conde de Gondomar para que éste informara en la Corte. Barros relataba el enfrentamiento con naves turcas que perseguían a unos navíos que buscaron amparo bajo la artillería de la plaza, movilizándose también las compañías de milicias. Por desgracia, no se había podido evitar la captura de un navío portugués y otro de vizcaínos que venían cargados el uno de manzana y nuez y el otro de azúcar y algo de pimienta; pero en ambos casos, sus tripulaciones lograron salvarse. La suposición general era que los turcos iban a saquear a lo largo de la costa gallega y por Asturias, pues traían navíos grandes con mucha gente de guerra:

\footnotetext{
${ }^{108}$ Carta de Francisco de Barros al Conde de Gondomar, 1619, octubre, 23.- Bayona, Real Biblioteca. Sig. II/ 2159.- doc. 71.

${ }^{109}$ Carta de Lázaro de Losada al Conde de Gondomar, 1619, octubre, 30.- Gondomar, Real Biblioteca, Sig. II/ 2159.- doc. 88 .
} 
En 27 de otubre, bíspera de San Simón y Judas a las ocho de la mañana binieron de mar en fuera por la buelta de Portugal tres navios de turcos y dos bergantines y tres lanchas esquifadas y muy bien armadas las quales benían siguiendo algunos navios que se anpararon devajo de la artillería desta fuerça, y al mismo punto acudió el sargento mayor Francisco de Varros tocando a arma con mucha puntualidad y diligençia, mandando juntar las conpañias de miliçia de la tierra de las quales ynvió la buelta de Nuestra Señora de la Çela con la suya al cappitán Pedro de Ybarra por pareçer lebarían los dichos navios alguna jente en tierra para saquear la ygleçia de Nuestra Señora, lo qual hizieran si no se acudiera tan a tienpo como se acudió, y no ostante lo arriva dicho, el dicho sargento mayor armó luego dos bolantes con jente de miliçia de la dicha villa dándoles orden anparaçen los navíos porque no se los llevasen los turcos que benían en su seguimiento, que fuera ynposible dejar de tomallos sin que fuera por los bolantes y artillería que ansimismo el dicho sarjento mayor hizo disparar de la torre del Príncipe, la qual fue de muy grande efeto porque los enemigos no salieran con desinio, porque visto el dano que les podría benir se retiraron un poco hacia la mar adonde tomaron un navio de portugueses que venía cargado de mançana y nues, al qual con una pieça de artillería desta fuerça que le alcançó se alló averse ydo a pique salvándose en el batel la poca jente que traýya, que por allarse algo apartado a la mar no se le pudo socorrer.

Tanvién tomaron otro navio de viscaýnos que venía de Lisboa cargado de asúcar con algunas sacas de pimienta, salvose tanvién la jente, la qual salió en el batel en el río dasos (?), y los demás se salvaron $y$ entraron en este dicho puerto y de todo dio aviso ansimismo al monesterio de Oya y villa de Voças y Vigo y a partes nesesarias para questubiesen con cuydado y bigilantes, para lo que se ofreçiese, y asimismo guardando la muralla de açia la torre del Príncipe con mosquetería y arcabusería y gente de la villa por lo que pudiese suseder. Probeyó tanbién algunas postas de la jente de la tierra asta que los navios piratas se fuesen, los quales el otro día de San Simón echaron la vuelta del cavo de Finisterra, de que se presume no dejarán de saquear algún lugar desta costa u de la de Asturias, por ser navios grandes y fuertes que traen mucha gente de guerra.

Por el momento el perjuicio no había sido mayor gracias a que por ser festivo aquel día los pescadores no habían salido a faenar. Pero lo que causaba más 
asombro era el extraordinario porte y buena fábrica de los navíos musulmanes, muy bien pertrechados y capaces para acometer cualquier acción. Barros Troncoso, informado de sus movimientos, pedía al Conde de Gondomar que noticiase a Su Majestad del daño que los moros estaban causando en toda la costa:

A sido Nuestro Señor servido vinieran en día de fiesta que no avía ydo barco ninguno a la mar, que a no ser ansí recibiera esta tierra notable daño que no dejaran de aver cautivado mucha jente, Nuestro Señor lo remedie y se acuerde de nosotros.

Los navios de los piratas son de porte de a quatroçientas, y de a treçientas, y de a duçientas toneladas, que pueden llevar por lo menos más de seiscientas personas de guerra y capaçes de llevar mill, $y$ con los bergantines y lanchas azer qualquiera [efeto?] y mucho daño en toda esta costa donde ubiere descuydo, y lo que hizo el sargento mayor a sido por estar yndispuesto y en cama el cappitán Diego de Grijalba a cuyo cargo está esta fuerça.

$Y$ en 29 deste, fueron los barcos de bolante desta villa y algunas caravelas de pescar naturales de Asurar (*) y Vila de Conde y Esposende, que es en Portugal, a coger el aparejo que tenían en la mar, ynformándose el dicho sargento mayor dellos, dijeron abian visto belas açia la parte de la ysla de Ons derechos a la parte del Norte. $Y$ aziendo ynformación el dicho sarjento mayor si estos navíos avían echo algún dano en la parte de Portugal, alló por muy cierto y por aviso que de San Juan de Fos y Puerto avían llevado al pie desto personas pescadores.

Bienen muy pertrechados y aderesados y muy linpios, no pareçiendo le falta cosa y ensevados, y pareçen vienen de fresco, y desto doy avisso a Vuestra Señoría como persona çelosa del serviçio de Dios y de Su Magestad el Reydon Felipe, que Dios guarde, que se lo avise ${ }^{110}$.

Los daños que los musumanes causaban en las costas de Galicia y Portugal eran muchos y sus naves llegaban de manera incesante. Ante la falta de tropas

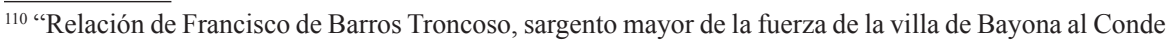
de Gondomar", (S.1., s.d.), Real Biblioteca, Sig. II/2159.- doc. 74. La data conjetural de este documento en el catálogo de la Real Biblioteca es 30-V-1619, pero debería ser 30 del X de 1619, o sea, octubre, en base a las cartas de Barros Troncoso sobre estos sucesos y la referencia a la enfermedad del capitán Grijalba, que se repite en la otra Relación dirigida al Conde de Gondomar por dicho sargento mayor.
}

* Azuara. 
regladas en número suficiente, el remedio más recurrente para reforzarlas consistía en echar mano de las milicias de paisanos, que en opinión del sargento mayor cumplían su misión con efectividad más que satisfactoria:

Después de aver scripto la postrera a V.S. a suçedido lo que V.S. berá por esa relaçión que va con esta y echará de ver, pues es tan seloso de las magestades divina y umana, el mucho dano que los moros azen en toda la costa de Portogal y la deste Reino, y aora me pareçe se enpieça como si confináramos con Turquía y lo mucho que ynporta el remedio para que V.S. ynforme a todos esos señores del Consejo y a Su Magestad.

Las conpanías de miliçia desta villa acuden y asisten como si fuera ynfantería pagada a estas ocaçiones y a la guarda desta fuerça, y asiguro a V.S. que están de ordinario tomando las armas de noche y de día acudiendo a las partes nesesarias para ynpidir no salten en tierra y enbarcándose en bolantes para el socorro de los barcos, que Su Magestad no tiene mejor miliçia en Espana que con tanta boluntad lo agan y es dina de premio, y lo mesmo la del Balle de Minor ${ }^{111}$.

Durante unos pocos días, a primeros de noviembre, pareció que la amenaza corsaria remitía, pero sus barcos andaban muy cerca, por la costa de Caminha y la isla de Ons, y no había manera de librarse de ellos:

Después no llegaron más piratas a estas yslas y bista desta villa, pero tanto monta, pues en las yslas de Onis (sic) ay dos. Y estos días andan otros dos desde Viana a la Guarda y con las lanchas siguieron las pinaças de Camiña que salían a pescar, y siendo favoreçidas de las de la Guarda, adonde se recojieron todas, y las lanchas se huyeron, quiso Dios no tomasen ninguna jente. No ay sacallos deste paraje ni remedio para ello. Probealo Dios por quien es ${ }^{112}$.

El día 8 un navío mercante francés de Olonne procedente de Lepe, en Andalucía, cargado de vino, pasa, almendra e higo, aportó a Baiona, donde denunció

\footnotetext{
${ }^{111}$ Carta de Francisco de Barros al Conde de Gondomar, 1619, octubre, 30.- Bayona, Real Biblioteca, Sig. II/ 2159.- doc. 75 (la data del mes de mayo que registra el Catálogo está equivocada).

${ }^{112}$ Carta de Francisco de Barros al Conde de Gondomar, 1619, noviembre, 5.- Bayona, Real Biblioteca, Sig. II/ 2159.- doc. 162.
} 
que había sido robado por los corsarios turco-berberiscos. El sargento mayor de la plaza realizó la pertinente visita de la embarcación y supo por su maestre, Joséph Pigeon, que dos días antes se había encontrado con tres navíos de turcos mar adentro a cuatro leguas de las islas Cíes,

...y allí, estando en calma, le abordó el uno dellos, y que les dio muchos palos y rabancassos (sic), y los navios tres de porte de a duçientas y treçientas toneladas con veinte y çinco piesas de artillería asta treynta, de que algunos de los dichos franceçes venieron muy maltratados y les robaron y llevaron ochenta varriles de ygo blanco y ocho pipas de vino y algunos barriles de passa y almendra y toda la ropa de bestir y de las camas con que dormían y belas y anclas, que todo ynportaría al pie de dos mill ducados.

También se llevaron todas las armas del barco, que consistían en doce mosquetes, doce picas y cuatro espadas.

Los corsarios interrogaron a la tripulación (que, grandes y chicos benían treçe), si habían encontrado algunos otros navíos turcos durante la travesía, a lo que los franceses respondieron que no. Pero aquellos les replicaron que no era posible, porque habían salido de Argel y otros puertos sesenta navíos, los cuales habían de reagruparse. A continuación les dijeron que el embajador de Francia se hallaba en esa ciudad, y que había paces.

Los franceses, sorprendidos y ensangrentados a causa de los golpes, preguntaron por qué entonces les robaban y les maltrataban tanto, contestando los corsarios, que porque [el navío] no avía amaynado luego las belas lo acían; no obstante, después les permitieron continuar la navegación ${ }^{113}$.

Como Barros Troncoso quería mantener bien informado al Conde de Gondomar, el 12 de noviembre le comunicó que le enviaba la memoria de esta visita con la esperanza de que la diera a conocer a S.M y al Consejo. Asimismo, el sargento mayor recordó al Conde como las pinazas de A Guarda habían intervenido en Caminha unas lanchas turcas, comentándole con cierta sorna como esta acción había merecido el muy dudoso elogio de un hidalgo portugués:

Para que V.S. ${ }^{a}$ entienda la bellaquería destos turcos ynbío la relaçió<n> que ba con esta y para que V.S. ${ }^{a}$ la pueda azer a Su

\footnotetext{
${ }^{113}$ Relaçión de una bisita que hizo Francisco de Varros, sarjento mayor de la villa de Vayona de un navio francés natural de $<O>$ lona que aportó a la dicha villa y puerto della en ocho de noviembre de mill y seisçientos y diez y nueve. Bayona. Real Biblioteca, Sig. II/ 2159.- doc. 147.
} 
Magestad y a esos señores del Consejo, con çerteça no seré largo por no ser enfado y remitirme a lo que hescribi a V.S. ${ }^{a}$ con los tres hordinarios pasados. V.S. ${ }^{a}$ se acuerde de mi en lo que tengo suplicado, favoreçiéndome con Su Magestad y con esos señores si mis serbiçios y hedad lo mereçieren. En los otros hordinarios hescribi a V.S. ${ }^{a}$ de cómo las pinaças de la Guarda socorrieron a los de Camiña que las tenían casi cojidas como fuera sin duda dos lanchas de turcos que se huhieron a las pinaças de la Guarda y se balieron los de Camiña, no quiera V.S. ${ }^{a}$ saber más de lo que dixo un fidalgo portugés en Camiña como supo lo que avían echo los de la Guarda y los de aqui con otras lanchas, dixo "Ja agora teremos hos galegos por homes, que ata agora non os tímamos por tais, que quitan que hos nosos non sejan catibos" ${ }^{114}$.

A continuación de la memoria de la visita, Barros Troncoso insertaba otra carta fechada también el 12, en la que hacía referencia a tres navíos turcos que ya habían estado en Baiona anteriormente. En su relación anterior al Conde, había dicho de ellos, que yban a la buelta del cabo de Finisterra, expresando su temor de que pudieran realizar algún asalto sobre las costas de Galicia y Asturias, temor que por desgracia se había hecho realidad:

Después que abisé a V.S. ${ }^{a}$ que los nabios que llegaron junto a la artillería desta fuerça de turcos que heran los tres que hescribi que yban a la buelta del cabo de Finisterra, y que no podian dexar de dar asalto alguno en este Reyno y en Esturias (sic), ay nueba çierta como ellos y otros que se juntaron quemaron el lugar de Finisterra y otras dos feligresías más beçinas de dicho lugar y cautibaron mucha jente, degollaron a los biejos y niños que no heran de serbiçio y saquearon las yglesias. Ya abrá allá abiso de la Coruña.

Esta acción recordaba mucho a la quema de Cangas, y Barros añadía que iguales males hubieran perpetrado en Baiona y otras partes de la ría si se hubieran descuidado, atribuyéndose el propio sargento mayor no poco mérito con ocasión de aquel ataque. Pero a pesar de mantenerse vigilantes, el 11 de noviembre una lancha de turcos había podido llegar a Vigo de noche logrando capturar una pequeña embarcación:

\footnotetext{
${ }^{114}$ Carta de Francisco de Barros al Conde de Gondomar, 1619, noviembre, 12.- Bayona, Real Biblioteca, Sig. II/ 2159.- doc. 159.
} 
Lo mesmo hizieran por aquí si estubieramos descuydados, Dios lo remedie como puede y se castigue a quien tenía lo de Finisterre a cargo y lo de Cangas, y se aga merced y honrre a quien lo trabaxa y sirbe, y no aberse quemado Boças y otras partes quando se quemó Cangas a mí se ubieran de dar las graçias y premio y se dieron a otros, yo gasté mi azienda en asistir en Boças y en las marinas y maté dos caballos y después estube enfermo y bien malo de puro trabaxo, que no tengo agora menos en acudir a tantas partes desta marina y costa, como todos los que ban a esa Corte podrán ynformar de la manera que sirbo.

Son ya tan ladinos los turcos que ha quatro días no pareçía nabio, $y$ de noche tenían la lancha en Bigo, donde sacaron un barquillo con su jente, y a las ocho del día binieron a las hislas a buscar la lancha, adonde estubo asta agora aziendo agua, oy doçe se hizieron a la mar $^{115}$.

Por las mismas fechas, el capitán de Baiona, Diego de Grijalba, se quejaba al Conde de Gondomar de la osadía de los corsarios, cuyas razzias despoblaban la costa, manifestando su impotencia para detenerlos, a pesar de infligirles algunos golpes, y su deseo contar con más efectivos y pertrechos:

...siento mucho que aya de allar el lugar y la tierra toda tan despoblada y perdida con la asistençia de los turcos en esta costa y el atrevimiento que toman de saltar en tierra y de meterse casi donde les alcança el artillería desta fuerça sin que podamos haçer otra cossa sino mirarlos, aunque hes verdad que una o dos veçes se les ha ronpido la cabeça a sus lanchas con la gente que de aqui ha salido en nuestras pinaças. Vien sé que de todo esto tiene Vuestra Señoría aviso, y el poco remedio que se da nos haçe a todos estar confusos, sólo quisiera ver esta conpañía con más gente y esta fuerça poblada y con bastimentos y muniçiones, todas estas faltas verá Vuestra Señoría aqui'116.

\footnotetext{
${ }^{115}$ Carta de Francisco de Barros al Conde de Gondomar, 1619, noviembre, 12.- Bayona. Real Biblioteca. Sig. II/ 2159.- doc. 147.

${ }^{116}$ Carta de don Diego de Grijalba al Conde de Gondomar, 1619, noviembre, 11.- Bayona. Real Biblioteca. Sig. II/ 2159.- doc. 145. Un mes después, Diego de Orozco comentaría la acción de estas pinazas en carta desde Madrid al Conde de Gondomar: ... abiendo salido los bolantes a pescar, parezieron quatro navios de moros y las mugeres de los pescadores fueron a dar vozes al capitán Grijalva que socorriese a sus mandos, él dijo que lo oía. Pero juntándose cinquenta honbres tomaron por caudillo al que fue mi alguazil mayor que fue mío y salieron y los moros pensaron que eran pescadores los dos varcos en que yban y entraron
} 
En términos parecidos se expresaba otro capitán de Baiona llamado Gregorio de Castro, quien en una larga carta al Conde se lamentaba de los continuos enfrentamientos con los corsarios y del buen comportamiento y destreza de la milicia local, a pesar de lo cual no podían garantizar la seguridad de sus casas:

Luego quisiera no tener tanta ocasión descrebir a V.S. ${ }^{a}$ tantas bezes cosas de moros y turcos, mas como esto es cosa de V.S. ${ }^{a}$ no puedo dexar de abisar de lo que ba sucediendo, que por nuestro pecados o por lo que Dios sabe sienpre de continuo los tenemos aquí por vezinos e ya no ay barco que se atreba a salir a la mar a pescar sin escolta. El sábado pasado y los días atrás estubieron en las islas dos nabíos grandes y buenos, y el domingo por la mañana dieron bela y se fueron la buelta del cabo de San Biçente, y el lunes se descubrieron otra bez, porquel ayre se bolbió de bendabal y se binieron a las yslas, y como se abía despedido la gente que baja para defensa destos puertos la bolbieron luego azer benir y es la mayor conpasión que puede ser ber la miseria y pobreça, quiera Dios que no nos beamos en neceçidad, que yo no se como gente tan desalentada se a de poder animar para azer cosa buena. La gente de Bayona está en muy buena reputación graçias a Dios, porque anteayer llegó a Bayona un nabio francés a quien los turcos abían tomado y buelto a soltar abiéndole sacado alguna cosa de lo que traýan porque dizen que tienen conçierto con ellos y los que benýan en él dixeron que los turcos dezían que los de Bayona azían muy mala guerra porque mataban y que ellos no hazían más que cautibar, que por qué no abían ellos de azer lo mismo, mas que de aquí adelante que de Bayona no tomarían ninguna a vida y la causa desto fue que de algunas salidas que los de aquí salieron? una mañana se bino una lancha a ellos con gran algaçarra dándoles bozes en muy buen lenguaje español, y los nuestros los reçibieron con una muy buena ruçiada de arcabucería y mataron algunos, que fue causa que bolbiesen huyendo con más cuydado del con que benýan, y después acá enbíando barco de Bayona no ay lancha que no baya luego uyendo, hes muy buena jente la de Bayona y muy diestra en el manejo de las armas, y se enbarcan con tan buen ánymo que yo me está llorando el coraçon de no podelles gratificar con alguna obra tan honrrado

con ellos y ellos les dieron una carga y mataron cinco o seis y hirieron muchos y se retiraron y bolvieron en salvo los pescadores y ellos. Diego de Orozco al Conde de Gondomar, 1619, diciembre, 14.- Madrid. Real Biblioteca. Sig. II/ 2159.- doc. 170. 
yntento, de palabra se lo agradezco y doy muchas graçias, ni de aquí adelante no las consintiré que vengan a la mar azer gentilezas porque podrá suçeder alguna disgraçia, que los enemygos están sobre abiso y le podrán azer [...], y es gran lástima que no les den algo con que se animen, pues continuamente están sirbiendo al Rey, lo que no azen ningunas conpanías, porque si no hes en la ocasión ninguno sirbe, y ellos siempre jamás con las armas en las manos ayudando a los soldados pagados que son arto pocos que no pasan de sesenta los que toman armas y con los vezinos se aze la guarda $y$ dexan de trabajar para sustentarse por suplir la falta de la jente de guerra, y cada día se me ban de mi conpanía a sentar la plaça a la del cappitán Grigalba (sic) y dizen que pues an de serbir así que así que quieren goçar del Real y con esto bendré yo a ser capitán de nonbre y no de conpanía y hesto es bien que tenga algún remedio porque el vezino questan buen soldado como el pagado ayuda a la defensa y escusa dos conpanías que abía de aber aqui porque si la de Grigalba tubiese número capaz con los vesinos sería cosa de mucho momento para la defensa desta fuerça, mas no tiene la terçia parte de la gente que conbiene y me ba desmenuyendo mi conpanía de manera que por tienpo bendré a ser capitán de vesinos de Bayona y no de soldados. Suplico a V.S. ${ }^{a}$ mire este punto y no consienta V.S. ${ }^{a}$ que se me pague tan mal tantos años de serbiçio, que no los e yo enpleado tan mal que aora me dexen sin compañia, porque a fe que he gastado buena parte de mi azienda en serbiçio de Su Magestad con la conpanía y antes de tenella y aora con la asistençia, sabe Dios lo que pasa, que por Justicia podía yo pedir que se me gratificase y se me yziese merced, que aún el Ebangelio lo dize quel que sirbe hes dino de que le paguen, y como otras bezes he dicho a V.S. ${ }^{a}$ no es mi conpanýa como las demás, porque ninguna ay que si no hes en la ocasión sirba y la mía sienpre ayudando a la falta de la gente de guerra, y es causa y escusando muchas plaças que Su Magestad abía de pagar si tubiese aquí gente pagada la que fuese menester. Al fin señor concluyo con que si no se piensa mucho en el remedio destos corsarios no quedará ningún lugar abierto en estas rías con bezino y todas se despoblarán porque ya no ay ninguno que se atreba a tener cosa en casa aguardando que se lo roben y quemen una noche ${ }^{117}$.

\footnotetext{
${ }_{117}$ Carta de Gregorio de Castro al Conde de Gondomar, 1619, noviembre, ¿?.- Bayona, Real Biblioteca, Sig. II/ 2159.- doc. 108. Según el Catálogo, la carta esta fechada en 20 de noviembre, pero a tenor de su contenido debió haber sido escrita el 11 ó 12 de dicho mes.
} 
El 14 de noviembre Barros Troncoso avisaba al Conde de Gondomar del envío de su relación. Desde Baiona se podían observar once navíos gruesos de corsarios moros, llegados dos días antes, que no dejaban de acechar la costa, por lo que se se habían tomado las precauciones habituales:

Por este ordinario que partió ayer, escriví a V.S. ${ }^{a}$ y ynvié una relaçión de lo que passa por esta tierra a que me remito, luego antiaer apareçieron y quedan a la vista desta villa y pegados a las yslas della onze navíos gruesos, y al tienpo que apareçieron era por la manana que venían de la buelta del cabo de Finisterra, y luego recogí toda la milicia y conpanías y desde el monesterio de Oya asta San Miguel de Oya está guarnecido de jente que no eche lanchas en tierra, que todo tienen cojido con ellas esta costa y los navios quedan a la vela en este mesmo paraje que digo entiéndese se juntarán más. Quiera Dios no agan algún asalto donde aya descuydo aunque a todas partes tengo avisado y los pescadores recojidos, y asta aora no savemos ayan cojido barco.

El françés que llegó aquí robado de los turcos que avisé a V.S. ${ }^{a}$ dicen se quejava mucho desta villa por aver muerto los dias pasados siete turcos de sus lanchas con los barcos que de aquí salieron y quellos no benían sino a cautivarnos y no a matar y que los que pescasen de aqui avian de aber crueldad con ellos ${ }^{118}$.

Desde Oporto hasta Finisterre - decía- estaba todo arruinado por los musulmanes, que habían tomado gran cantidad de cautivos. En tan graves circunstancias el sargento mayor ponderaba el esfuerzo y sacrificio de las milicias, armadas y municionadas a su propia costa cuando era S.M. quien debería proveerles;

$Y$ aquí se anda siempre con las armas a cuestas y a su costa y gastando sus aziendas conprando las muniçiones que sería justo Su Magestad les probeyese dellas para estas ocaçiones. V.S. ${ }^{a}$ no deje de proponello a Su Magestad doliéndose destas cosas, y que aya orden de echar estos navios desta costa porque todo lo que ay de mar desde el Puerto de Portogal al cavo de Fenisterra está todo tomado y ocupado, de suerte que lo tienen todo arruynado y parte dello ya cautivado ${ }^{119}$.

\footnotetext{
${ }^{118}$ Carta de Francisco de Barros al Conde de Gondomar, 1619, noviembre, 14.- Bayona, Real Biblioteca, Sig. II/ 2159.- doc. 110.

${ }^{119}$ Ibidem.
} 
Al fondo de la ría de Vigo, el franciscano fray Joan de Lis escribía desde el convento de la isla de San Simón de Redondela comentando los muchos daños que causaban los corsarios musulmanes. Se despoblaba la costa y habían quemado Fisterra llevándose a mucha gente cautiva, y en la propia ría aún permanecían trece embarcaciones con seis lanchas acechando los puertos:

...por la esterilidad del año, se ha ido nueba gente y em particular de los puertos, y desde el de la Guardia asta el Carril, de la toma de Cangas, faltan por más de dos mill y quinientas personas, y ahora poco ha quemaron a Finistierra con siete feligresías, y fuera los muertos, llevaron cautibas ciento y çinquenta personas y nuevo número de todo ganado; al presente quedan quatro galeones y otros nuebe nabios gruesos en la Ría de Vigo, con seis lanchas de más de sesenta hombres que voltean los puertos que según sus débiles fuerças los be sugetos a qualquier mal suseço si las de Su Magestad no acuden al remedio... ${ }^{120}$.

Como muchos otros de la ría, varios pescadores de Redondela fueron capturados en este año de 1619. Llevados a Argel, su redención al año siguiente por mediación de los frailes Mercedarios conllevó un desembolso económico (abono a esta Orden en concepto de limosna del precio que alcanzara el cautivo en el mercado esclavista) que en muchos casos sólo podía ser afrontado mediante el préstamo y el endeudamiento:

...y abiendo tomado los moros el ano pasado de mill y seisçientos $y$ diez y nuebe a Domingo do Casal, mareante, honbre de hedad de asta veinte y seis anos, alto de cuerpo, y es notorio está en la çiudad de Arjel cautibo Por tanto que ella dende luego por el sobre dicho se obligaba y obligó con su persona y vienes muebles y raizes avidos y por aver que aziéndole caridad y limosna la horden de Nuestra Senora de la Merced y su Redentor en su nonbre de redimirle y resgatarle, pagará estando en el Reino d'Espana conforme a la dicha horden seis ducados puestos y pagos a su propia costa en la çiudad de Santiago en el dicho monasterio de Nuestra Senora de la Merced ... ${ }^{121}$.

\footnotetext{
${ }^{120}$ Carta de Fray Joan de Lis al Conde de Gondomar, 1619, noviembre, 16.- Isla de San Simón, Real Biblioteca. Sig. II/ 2159.- doc. 144.

${ }^{121}$ Según las otras escrituras de obligación que se realizaron, las cantidades que se exigían variaban en función de la edad y las características físicas de los hombres capturados. Por lo que respecta a los demás marineros, se pedían doce ducados por Domingo das Táboas, mareante moço de hedad de asta veinte años,
} 
El 19 de noviembre, Francisco de Barros informó desde Baiona que diez navíos enemigos se habían hecho a la vela, pero ya nadie dudaba de que estos o cualquiera otros no tardarían en retornar; el sargento mayor aprovechó entonces para una breve ausencia de la plaza, pero sin dejar de mantenerse alerta:

\begin{abstract}
A 19 deste se hizo el pirata que estaba en las yslas de Bayona a la bela con diez navios gruesos y de fuerça y con bento norte reçio y al pereçer se engolfuó según el término? que le açía y le llebaba la derrota dejóme vien cansado y me cansará así como desapareçió me bine a besar las manos al señor Qonde de Salvaterra que parte manana a esa Corte a que me remito. Yo luego me buelbo a Bayona que aze bento bendabal que poder aser buelba el pirata o otros ${ }^{122}$.
\end{abstract}

El 4 de diciembre, Barros no tenía más remedio que dar más noticias al Conde de Gondomar sobre la presencia de piratas en la costa y de los muchos navíos que un gran temporal de vendavales había arrastrado al puerto ${ }^{123}$.

Como ya era previsible, en los meses siguientes se repitieron los avistamientos de buques corsarios. Las Cíes eran una buena estación de reparación y aguada en su ruta hacia el norte y los habitantes de Baiona experimentaban ya el cansancio de cuatro años de lucha continua contra un río de piratas y corsarios que no tenía visos de tener fin. Al respecto es revelador el tono de apatía con que el capitán Grijalba informaba al Conde de Gondomar, el 16 de mayo de 1620, sobre el aviso de que otra escuadra turca andaba por la costa:

La semana pasada tuve aviso del gobernador de Oporto de dies y
seis navios de turcos que andan en esta costa, los quales estamos
aguardando con el cuidado que se puede, pero la gente está

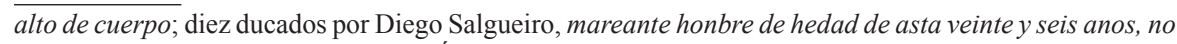
muy alto de cuerpo; seis ducados por Álvaro Blanco, mareante honbre de hedad de asta treinta y quatro anos, no muy alto bajete de cuerpo; mil reales por Joan Rodríguez da Cal, mareante, honbre de asta treinta y quatro anos, no muy alto de cuerpo, regordete; y veinte ducados por Pedro do Couto, mareante, moço de hedad de asta veinte y quatro anos y alto de cuerpo. 1620, mayo, 21.- Redondela. AHPPo., protocolos notariales de Ventura Troncoso, Ca. 4768 (carp. 6), fols. 74r.-77v. y 79r.-v., en José MARTínez CRESPO, A Guerra na Galicia do Antigo Réxime (ss. XVI-XIX). Textos e contextos, Noia, Editorial Toxosoutos, 2007 (Colección Anais), págs. 326-328.

${ }^{122}$ Carta de Francisco de Barros al Conde de Gondomar, 1619, noviembre, ¿19?.- Tuy, Real Biblioteca, Sig. II/ 2159.- doc. 109. Según el Catálogo, la carta esta fechada en 12 de noviembre, pero la cifra es dudosa y podría leerse 19 .

${ }^{123}$ Carta de Francisco de Barros al Conde de Gondomar, 1619, diciembre, 4.- Bayona, Real Biblioteca, Sig. II/ 2132.- doc. 198. 
desarmada y descontenta por los malos años que Dios ha sido servido darnos de quatro a esta parte... ${ }^{124}$

Más al norte, la villa de Finisterre, que era por entonces, lugar de muy buena población pero sin ninguna defença, fue quizás la que más sufrió los rigores de la terrible razzia corsaria de 1619, pues, Fue saqueada y quemada casi toda de moros, y llebaron a Argel muncha gente cautiva, abrasando la yglezia y quemando las ymágenes. Como en Cangas, aquí también había un Cristo crucificado que los turcos berberiscos no consiguieron destruir:

Está en esta yglezia, que es un tenplo muy grande y ermoso todo de cantería y bóbeda, una capilla donde tienen una ymagen de hun Cristo cruçificado de mucha devoçión, que afirman ser de la misma antegüedad y echura del de Burgos. Y entrando hio en la yglezia a ver el daño y desacato que aquellos ynfieles avían echo en la yglezia y a las santas ymágenes, vi que el Cruçefixio estava sano y sin daño ninguno, siendo ansí que todas las demás estavan despedasadas y cortados los braços y cabeças y otras medias quemadas y con muchos arcabuzaços que les tiravan. Me ynformaron muchos onbres, que en aquella ocazión fueron cautivos y avían buelto de rescate, que los moros no ablavan sino en el espanto y turbaçión que sintieron quando yntentaron poner las manos sacríligas en aquella santa ymagen, que no sólo le faltó el ánimo sino con gran prisa huyeron de la yglezia y dexaron el lugar, enbarcándose con espantable miedo y prisa. Milagro siento de gran consideración que parese querer Dios mostrar su poder a aquellos ynfieles y que permitió su atrevimiento para castigo de aquel lugar ${ }^{125}$.

La continua acción corsaria afectaba a todo el tráfico mercante obligado a pasar ante Finisterre, convirtiendo este cabo en uno de los puntos más peligrosos de la costa. Muchos comerciantes eran capturados en él con sus naves, por lo que se le llamará -en una variante del apelativo de su costa- el "cabo del Muerto"126.

Galicia pasó por entonces a formar parte de la geografía de los lugares más inseguros para la navegación a causa del corso berberisco. Desde La Rochelle a Lisboa sus naves enseñorean el océano. Las rías gallegas y las islas Berlengas (en

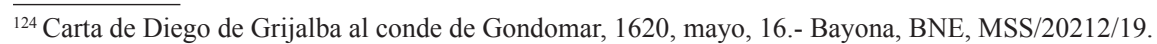

${ }^{125}$ P. TeiXeira, “Descripción de España...”, fols. 36v.-37r., pág. 329.

${ }^{126}$ R. FeiJoo, Corsarios berberiscos..., págs. 126-127.
} 
la costa portuguesa) son excelentes parajes que permiten a los corsarios de Argel y Salé emboscarse para caer por sorpresa sobre las desprevenidas embarcaciones de cualquier país cristiano $^{127}$. Aguas dentro del cabo Finisterre es apresado en 1624 Thomás Delapsan, francés de Bayona, junto con 52 compañeros con los que había salido a pescar bacalao en Terranova. La misma suerte corren, en 1625, el grumete inglés Jacob Albert y otros tres jóvenes marineros, capturados mientras navegaban en una pinaza flamenca abordada por los argelinos cerca de dicho cabo ${ }^{128}$.

La consecuencia más evidente será el aumento del número de cautivos procedentes de esta área geográfica. El Atlántico central (sur de Bretaña, Galicia, Portugal y Canarias) registra en esta época, según Benassar, el 18'68\% de las capturas corsarias, ocupando el tercer puesto en porcentaje tras la zona del estrecho de Gibraltar (28\% de capturas) y el Sur del mar Tirreno y el estrecho de Sicilia (20,60\%). Sorprendentemente, por debajo de estos porcentajes se situan el Mediterráneo Oriental (14’56\%); Baleares y el Golfo de León (7’14\%); más lejos quedan los porcentajes de capturas realizadas en el Atlántico Norte (Canal de la Mancha y Terranova, 6’31\%), y el Adriático (3’84\%). Según estos datos, el volumen de cautivos procedentes del Atlántico Central llegó casi a igualarse al de la región siciliana, cruce de caminos de todo el Mediterráneo, obteniendo los corsarios musulmanes prácticamente la misma cantidad de apresamientos en el Atlántico Norte que en las Baleares, justo frente a Argel ${ }^{129}$.

La presión corsaria sobre las aguas gallegas era tan intensa que las actividades pesqueras, de las que dependía para su sustento una buena parte de la población, se vieron constantemente afectadas. Entre 1617 y 1621 se produjo un cierre parcial de la pesca en la ría de Vigo por la continua presencia de navíos corsarios ingleses y turcos, que en sus incursiones capturaban a los pescadores de ambas orillas mientras faenaban ${ }^{130}$.

En el norte de Galicia, la inseguridad del puerto de Bares, situado en el extremo del cabo del mismo nombre y usualmente utilizado por balleneros vascos, fue una de las causas que impidieron la gestación de los factores necesarios para el desarrollo de las tareas de pesca de cetáceos. Los constantes ataques berberiscos provocaron un estado de alerta permanente que en el primer tercio del siglo XVII

\footnotetext{
${ }^{127}$ Bartolomé y Lucile BenAssar: Los cristianos de Alá. La fascinante aventura de los renegados. Madrid, Editorial Nerea, 1989, págs. 203 y 235.

${ }^{128}$ Ibidem; págs. 193, 232 y 309.

${ }^{129}$ Ibidem; págs. 230-244. Benassar estudió los expedientes de 1.186 renegados, de los que 495 fueron capturados en el mar. 104 lugares no fueron identificados, por lo que la muestra real estudiada se realizó sobre 365 lugares identificados. Véase también R. Feisoo, Corsarios berberiscos..., pág. 127.

${ }^{130}$ M. Rodal GonzÁlez, “Afán de la justicia seglar...”, pág. 207.
} 
obligó a la comunidad ballenera vasca a desplazarse hacia otros lugares más protegidos del interior de la ría del Barqueiro o al puerto de San Cibrao:

Siempre están con las armas en la mano belando y estando centinelas cada instante por causa de los moros que hacen muchos daños quemando las casas como fue quemado [el puerto] tres veces, asustando a los biscaynos, que no vuelven con sus chalupas ${ }^{131}$.

Pero si la actividad corsaria afectaba a la pesca, también ocurría lo mismo con las labores de salazón, necesarias para la conservación y exportación del pescado.

El tráfico mercante incluía un producto tan indispensable entonces como la sal, y su provisión a los alfolíes gallegos y asturianos constituía una de las rutas mercantiles más demandadas durante el Antiguo Régimen en el área atlántica peninsular. La sal era imprescindible para la curación y conservación del pescado, pero también de la carne, y su comercio implicaba anualmente a más de cien carabelas portuguesas, que transportaban cada año el preciado conservante a los alfolíes gallegos y asturianos desde las salinas de Aveiro.

Durante la vigencia de la Tregua de los Doce Años con holanda (1609-1621) esta ruta gozó de una gran seguridad, pero a partir de 1621 los corsarios turco-berberiscos fueron los encargados del estrangulamiento del tráfico mercantil de este y otros géneros ${ }^{132}$. En septiembre de 1622, el administrador del estanco de la sal, Diego de Orduña, se lamentaba de que los piratas habían impedido la navegación durante todo el año, y al siguiente la carrera de la sal quedó prácticamente paralizada. Parecía como si los berberiscos tratasen de compensar los asaltos no realizados a tierra acosando ferozmente las rutas comerciales. En julio de 1623, otro administrador del estanco de la sal, Fernando de Losada, informaba de cómo, la malicia de esta costa y cantidad de enemigos es de suerte que no a sido posible meter un navio de sal en este Reino; situación que generaba el desabastecimiento de los alfolíes, los cuales se encontraban sin, un grano de sal.

Los abordajes a las embarcaciones que transportaban este producto eran incesantes: en 14 de junio, de veinticuatro carabelas con carga de sal no consiguieron alcanzar los puertos gallegos más de dos, y otra más que se esperaba en Asturias; otra se había ido a pique al chocar contra los escollos, huyendo de los piratas. El resto hubo de buscar refugio en la desembocadura del río Douro, en Oporto, de

\footnotetext{
${ }^{131}$ Andrés Canoura Quintana, A pesca da balea en Galicia nos séculos XVI e XVII, [Santiago], Consellería de Pesca e Asuntos Marítimos - Xunta de Galicia, 2002, págs. 69-70.

${ }_{132}$ J. Juega Puig, El estanco de la sal..., págs. 406-407. Según este autor, estos corsarios procederían principalmente de Salé, donde contaban con la colaboración de marinos holandeses, demostrando la existencia de conexiones entre la política de las Provincias Unidas y el corsarismo y la piratería turco-berberisca.
} 
donde no se atrevían a salir. Tras la barra de Aveiro se protegían otras dieciséis carabelas, incapaces de iniciar su travesía. Hasta el 3 de junio de 1623 sólo se habían podido cargar en Aveiro veintidós carabelas portuguesas y dos navíos gallegos. Desde este momento la navegación quedó interrumpida, aunque volvería a reanudarse durante el invierno; era preferible enfrentarse con las tempestades que con los argelinos.

Por supuesto -ya se ha visto en otros apartados- los corsarios tampoco dudaban a la hora de atreverse a atacar a las naves de la carrera de las Indias Portuguesas, normalmente mejor armadas. En la víspera de San Juan de aquel año, arribó a Pontevedra una nao procedente de Brasil con carga de azúcares y cueros, pidiendo auxilio, cañoneando, malparada de los ataques enemigos. Constituía el resto de una flota de cuarenta y un navíos, de los que el enemigo había tomado catorce ${ }^{133}$.

En 1627, una carabela que se dirigía a Gijón fue perseguida y cañoneada por tres navíos piratas, teniendo que buscar refugio en Viveiro, donde encalló; la gente de la villa armada con arcabuces y mosquetes salió en su defensa, poniendo en fuga a sus perseguidores. Otra carabela procedente de Aveiro y también consignada a Gijón tuvo que buscar refugio en Pontevedra. A finales de ese mismo año, el administrador Orduña se quejaba del desabastecimiento de los alfolíes por estar el mar infectado de piratas durante todo el año. Hacía pocos días que éstos habían perseguido hasta la ría de Vigo a una carabela consignada a Pontevedra ${ }^{134}$.

En 1628, se produjo un colapso en la navegación por el incremento de la actividad pirática y corsaria. Las quejas de la Junta del Reino por el desabastecimiento de los alfolíes durante este año fueron constantes, sucediéndose de nuevo al año siguiente. Los pescadores habían dejado de pescar por falta de sal y se temió un brote de peste ${ }^{135}$.

La parálisis de los envíos portugueses al estar el mar cuajado de piratas y corsarios berberiscos hasta la altura de Viana do Castelo, obligó a los administradores del estanco de la sal a buscar otras alternativas. Se llegó a solicitar licencia para abastecer los alfolíes gallegos y asturianos desde las salinas bretonas, pero si bien este transporte evitaba la ruta establecida entre las salinas de Aveiro y las Rías Baixas, las embarcaciones debían navegar frente a puntos tan peligrosos como eran los cabos de Finisterre y Corrubedo ${ }^{136}$.

Las peligrosas travesías solamente podían realizarse con seguridad con naves muy bien armadas. Enrique Sinel, arrendador de la renta del estanco de la sal en los partidos de Galicia y Asturias desde junio de 1634, que tenía muy buenas

\footnotetext{
${ }^{133}$ Ibidem.

${ }^{134}$ Ibidem., pág. 27.

${ }^{135}$ Ibidem., pág. 408.

${ }^{136}$ Ibidem., págs. 416-417.
} 
relaciones en los puertos de Flandes, propuso echar mano de doce navíos holandeses bien artillados y provistos del correspondiente pasaporte, pues -ironias del destino- pertenecían a una república con la que la Corona española estaba en guerra casi permanente. Para evitar conflictos, se le exigió que las tripulaciones estuvieran compuestas por, vasallos, amigos o confederados de esta Corona o neutrales... viniendo con las armas y defensa necesaria ${ }^{137}$.

La inseguridad en los suministros llevó a que en 1634, en un intento por conseguir el autoabastecimiento, se reabrieran, como en la Edad Media, las salinas pontevedresas de la parroquia de Noaia, en el viejo Territorium Saliniense, actual Salnés, después de más de doscientos años abandonadas. También se concedió por Real Cédula el monopolio de construcción de salinas en Galicia y Asturias, aduciendo, entre otros motivos, los muchos corsarios que de ordinario asisten en aquellas costas ${ }^{138}$.

Pocos ReCURSOS Y MUCHOS PUERTOS QUE GUARDAR. LA DIFÍCIL DEFENSA DEL REINO

Los ataques al litoral gallego se sucedieron casi año tras año hasta convertirse en un mal endémico. Poca era la defensa que se podía oponer, porque de hecho, durante estos años, en la costa gallega, salvo en las plazas de realengo de Coruña y Baiona, no había fortificaciones con la necesaria potencia de fuego para frustrar con éxito una invasión; aunque la situación no era mejor en el resto del litoral Peninsular.

De la gran indefensión en que se hallaban los puertos gallegos en esta época, es ilustrativa la respuesta que en septiembre de 1620 dio el Marqués de Cerralbo, Capitán General del reino, a los avisos del Rey para que mirase por la seguridad y guardia de los puertos y castillos de su cargo ante un posible ataque holandés. El monarca pedía a Cerralbo que esto se llevase a cabo, escusando las demostraciones de prebención y la molestia de los naturales, a lo que el experimentado Capitán General no dudó en contestar con una franqueza y un pragmatismo encomiables:

Vuestra Magestad sabe que para estas prebenciones son menester gentes, municiones y bastimentos. Gente en este Reino ay tan poca pagada que se reduze toda a tres compañias, dos en la Coruña y una en Bayona, y las pocas plazas que ay en los quatro fuertes, que en todo serán 500 hombres efectibos con algunos entretenidos que pueden servir, lo que ay que guardar son cinquenta puertos,

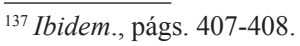

${ }^{138}$ Real Cédula concediendo a don Antonio de Mosquera el monopolio de la construcción de salinas en Galicia y Asturias., en J. Juega Puig, El estanco de la sal..., pág. 215.
} 
los quarenta y ocho sin defensa alguna. Para comprar bastimentos ni para otra cosa que salga del moderado socorro que se da a la gente de guerra no ay un real ni el Reyno tiene sustancia para poderlo sacar ${ }^{139}$.

También el Reino protestaba por la inseguridad que padecía, pero a pesar de la representación hecha por la Junta del Reino de Galicia, que en octubre de 1621 se quejaba de las, estorssiones... como las que de algunos años a esta parte han echo en las costas dellos turcos, moros, cautivando y robando lugares enteros ${ }^{140}$, la protección en tierra se limitó a una red cada vez más densa de atalayas y fachos situados a lo largo de la franja costera. Con una fuerza de fuego mínima, su operatividad defensiva resultó casi nula, limitándose a funciones de vigilancia por cuenta de naturales sin preparación militar que hacían el servicio por turnos ${ }^{141}$.

En estas condiciones, la precariedad de medios siguió siendo la nota dominante. La villa de Camariñas, aunque para su defensa tenía dos piezas de artillería de hierro, muy mal encavalgadas, en un terrapleno de tierra y faxina, era, de ordinario molestada de navios de moros que muchas bezes an querido acometerla saltando en tierra y llebando gente cautiva. Asimismo, en 1622, los corsarios musulmanes, avían llebado a Argel el cura y otras personas que estavan en una casa algo apartada del lugar ${ }^{142}$.

En ese mismo año, los ataques a varias localidades de la ría de Arousa fracasaron gracias a la resistencia armada de los vecinos, comandados por el cabo de las milicias del partido de Arousa y por el Señor de Fefiñanes y Sanxenxo ${ }^{143}$; pero los corsarios volverían más veces, y en 1630 se dio aviso de la presencia de tres veleros musulmanes en esta ría ${ }^{144}$. Igualmente, en 1620 y 1623 Corrubedo sufrió las correrías de los corsarios norteafricanos, los cuales infligieron un daño considerable al lugar. El Marqués de Cerralbo, lamentaba profundamente este suceso en una carta de 22 de diciembre de 1623 dirigida a uno de sus capitanes, manifestando su impotencia para detenerlos:

\footnotetext{
${ }^{139}$ Carta del Marqués de Cerralbo a Felipe III, 1620, septiembre, 27.- Coruña. A.G.S.-G.A., leg. 861, en M. C. SaAvedra Vázquez, Actividad militar..., pág. 348, nota 137.

${ }^{140}$ Sobre que se proceda al repartimiento de los cien mil ducados ofrecidos para la construcción de seis bajeles, 1622, marzo, 17.- Coruña, Actas de las Juntas del Reino de Galicia, vol. I, fol. 2r.-v. Doc. 61-A, pág. 233.

${ }^{141}$ J. M. VÁzQuez Lijó, La Matrícula de Mar..., pág. 73. Los fachos (antorchas) eran fuegos vivos que se hacían en lugares elevados para transmitir avisos.

${ }^{142}$ P. Teixeira, “Descripción de España...”, fol. 36r., pág. 329; J. M. VÁzQuez Lijó, ibidem, pág. 71.

${ }^{143}$ Emilio GonzÁlez LóPEz, Los políticos gallegos en la Corte de España y la convivencia europea: Galicia en los reinados de Felipe III y Felipe IV, Vigo, Editorial Galaxia, 1969, pág. 152, cita a José María Castroviejo, Galicia. Guía espiritual de una tierra, Madrid, Espasa Calpe, 1960, pág. 182.

${ }^{144}$ R. Feisoo, Corsarios berberiscos..., pág. 126.
} 


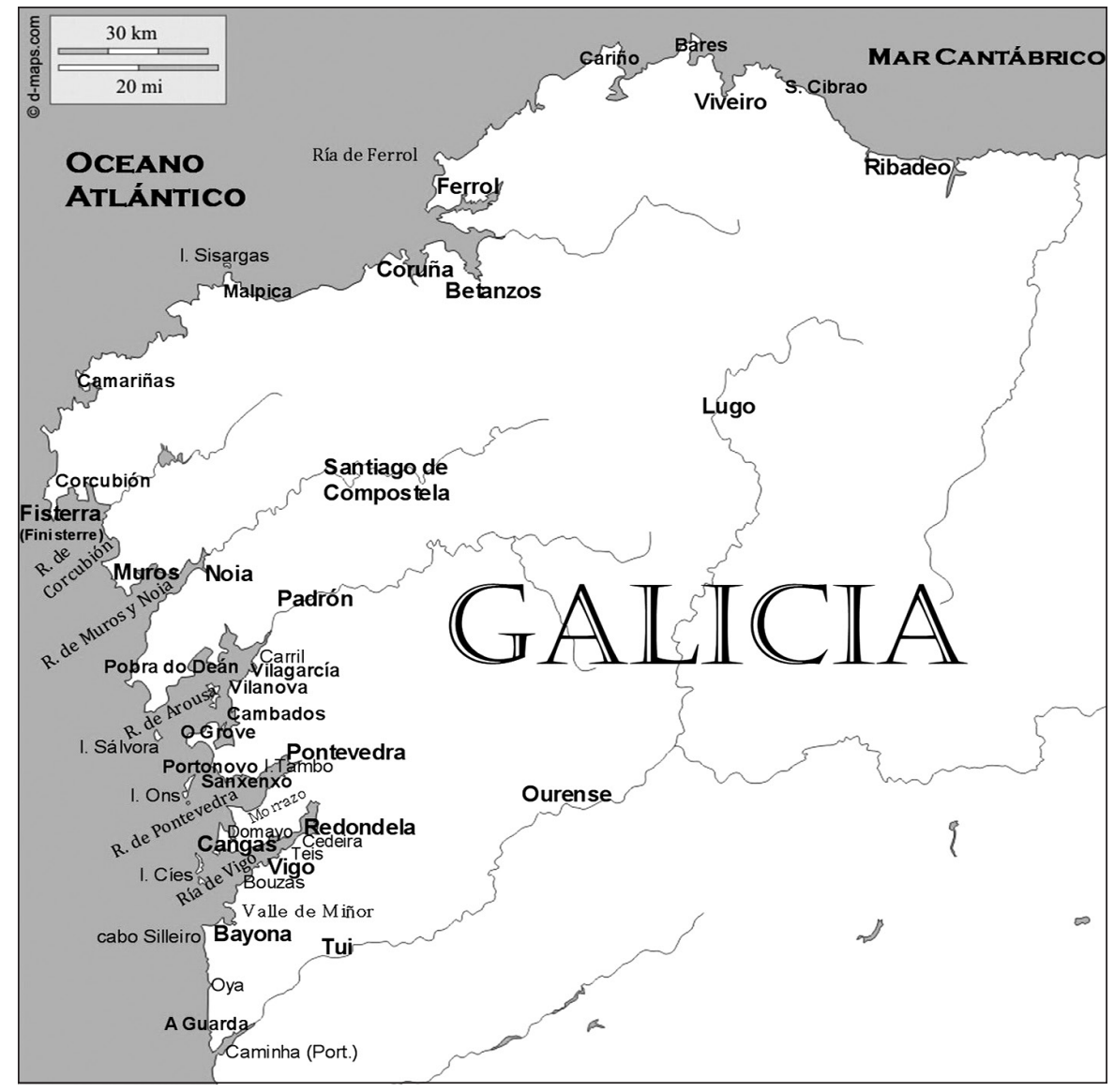

Fig. 4. Puertos de Galicia afectados por los ataques corsarios turco-berberiscos. Fuente: elaboración propia.

Qualquiera daño que haçen los Enemigos en la costa deste Reyno siento mucho, y que no tenga Bageles de Guerra en él para ynpedirlo, el que agora an hecho en Corrubedo me da pena, y que no se aya podido acudir allí tan a tiempo que no tomasen tierra los moros, abiseme V. merced muy particularmente de lo que pasó y si todavía llevaron alguna gente y quemaron casas, y lo que saquearon, prebiniendo las cosas de ese districto de manera que si otra ocasión se ofreciese ansi se halle la gente a punto para la defensa ${ }^{145}$.

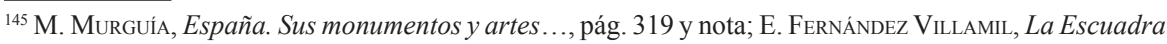
de Galicia..., pág. 17.
} 
El Capitán General había propuesto al Reino la creación de una escuadra de cuatro o seis navíos bien armados que pudiesen causar respeto a los corsarios, cuyas naves solían actuar en solitario y con muy poco riesgo para ellos:

...se deve conssiderar que los enemigos que mayor daño hazen en las costas y naturales de Galiçia no son los más poderosos, y que suelen enviar Armadas formadas, sino co $<r>$ ssarios sueltos y que si tubiesen al opóssito quatro o seis baxeles de guerra vien armados, no se atrevieran a yntentar lo que agora executan sin riesgo, y de faltar esta defensa resulta que los pescadores no pueden salir a sus pescas, ni los tratantes a acudir a sus tratos a Lisboa, Sevilla y otras partes, ni los forasteros a venir, con que çessa el comerçio y se van despoblando los lugares marítimos, cuya poblaçión es la más importante para la defensa del Reyno, pues son los puertos las murallas dél. Demás desto quiebra el corazón ver llevar cautivos a Argel, no sólo los honbres pero las mugeres y niños, aventurándose la salvaçión de tantas almas y la honrra de las mugeres, y perdiéndose las vidas y hazienda, y faltando al amparo de las cassas que acá quedan, que todo çessaría haviendo navios que lo defendiessen. En ellos serían pláticos los naturales del Reyno, ansí en las cossas militares como en la marinería, y los ya enseñados a navegar como fuessen creçiendo en caudal irían fabricando baxeles y acreçentando con ellos los tratos y comercios con que el Reyno se engrossaría ${ }^{146}$.

A falta de una protección oficial más efectiva, cada comunidad oponía sus propios recursos. En más de una ocasión, como ocurrió en 1624 y 1625, los monjes de Santa María de Oia se vieron obligados a disparar contra navíos musulmanes las piezas de artillería con que contaba el convento, tratando así de evitar que capturasen a los mercantes cristianos que perseguían:

$Y$ en veinte de Abril del presente [1624], en las horas que se les permite a los Religiosos entretenerse licitamente, para que la carne no pida lo ilícito, saliendo a espaciar la vista descubrieron (en el monstro enfrenado con el bocado de arena que le puso Dios) cinco navíos del África, o plaga oriental, que davan caça a dos de Portugal y Francia, naves merchantas, que conduzían lo que en

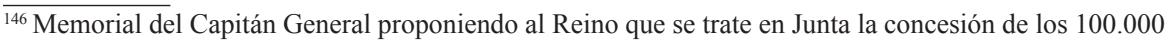
ducados ofrecidos a Su Majestad por el Voto en Cortes para la fábrica de una escuadra, 1621, Actas de las Juntas del Reino de Galicia, vol. I, fol. 59r.-v. Doc. 18-D, págs. 507-509.
} 
sus Provincias abunda, cuydado que debe honrar el Governador, pues siendo los Imperios disránbicos (sic), y que unos necesitan de las mercaderías de otros, los navegantes por medio de su cuidado y trabajo los unen.

Conocieron las naves Católicas serles superior el enemigo, y la poca defensa de las suyas, por ser de carga, y escogieron la mayor, desamparándolas sus náuticos, porque la calma no dava lugar a valerse del velamen, retirándose al puerto y surgidero que la violencia del mar, o algún vómito de la tierra hizo en las ripas del Monasterio, desseando abrigarse a la sombra de la artillería.

$Y$ es de advertir que con aver sido infestada toda la costa, de las classes Olandesas, de la Rochela y Ánglicas, antes de la tregua, y en ella (si bien siempre con poca reputación) jamás les ha permitido el que vela su grey asaltar el Monasterio: del qual advirtieron los Religiosos, que los navíos enemigos estavan casi rendidos, porque los soldados y gente de la tierra, en fee de costumbre antigua, assistían a unas caças o venaciones de lobos, de que abundan aquellas montañas: y ellos por redimir la vexación de sus ganados, haziendo de necessidad virtud, los persiguen. Los enemigos assi lo entendian, que ya les embiavan las lanchas para recebir los rendidos: y ellos desamparando sus naves, las dexaron a la discreción de la fortuna. Empeçaron del Monasterio a jugar la artillería; y los Monges se pusieron con sus mosquetes a resistir que no abordasse el enemigo; refriega que duro casi tres horas. Quedó al artillería un frayle de barba larga, llamado Fr. Pablo de Lescano, natural de Guadalaxara, que al fin era del Reyno de Toledo, donde no se conoce el temor, y avía sido en la mocedad gran soldado (que nunca los azeros de la soldadesca se pierden, pues la gracia no solo no destruye, sino perfecciona la naturaleza, ordenando los medios al fin) el qual assistió a disparar las pieças con otros dos Monges, que le servían de ayudantes, ó en fe del proverbio y de la ocasión, de medias cucharas; y aviendo disparado quinze tiros sin provecho, movido de afecto superior dixo; "Esta va" (al disparar la diez y seis) "en nombre de la Virgen María de Oya, y de mi Padre san Bernardo su hijo”. Logró el motilón el intento, pues obró la Virgen por medio desta pieza la redención de las naves Católicas, llevándose y echando a fondo una de las enemigas y la lancha que por el costado opuesto traía, yéndose a pique en un instante (que no pudiera con mayor celeridad averla desecho un rayo: mas la poderosa mano de la Virgen le fulminó en esta pieza. Y para que 
se vea esta manutenencia superior, no era la bala de dos libras de peso; murieron treinta y siete turcos, salieron a nado nueve que los monges cautivaron en la rivera, donde assistian a la defensa ${ }^{147}$.

Pero a pesar de estos pequeños enfrentamientos, los corsarios turco-berberiscos tenían naves poderosas y sus hombres eran guerreros experimentados, de manera que poco podían hacer contra ellos las pequeñas, abiertas e indefensas villas del litoral. No obstante, si alguna vez las encontraban prevenidas y con suficiente gente para resistirles, los musulmanes buscaban otras maneras de combatir, valiéndose especialmente del engaño y la sorpresa. Un buen ejemplo de sus tácticas y artimañas es la que emplearon para apoderarse de la confiada villa de Portonovo después de que esta consiguiera repeler una primera tentativa de asalto con la ayuda de los vecinos de Pontevedra:

...una mañana aparesieron enfrente deste luguar quinze navios de moros. Y acometiendo echar gente en tierra acudió la del lugar, dando avizo a la villa de Pontevedra que está quatro leguas de distancia della. Y socorriéndola con más de dos mil onbres, que luego binieron marchando, representaron en la plaia querer recibir al enemigo que se avía todo aquel día asta el otro estado dado fondo poniendo en orden el asalto. Y como vieron la muncha gente que a su defença avía acodido tomaron un acuerdo diabólico aziéndose a la mar asta que los perdieron de vista. Pensando se yban se fueron los de Puentevedra tanbién. Y los moros de parte de noche, ysieron otro bordo y se vinieron dar fondo a la ysla de Ons de la parte del poniente del, sin seren bistos de los de la tierra, segurándose ellos de la poca plática que de semejantes casos tienen. Y a la mañana, con bonança, echaron las lanchas a la mar con su gente y los navios atrás. Vinieron de detrás de la ysla por espaçio de legua y media y desenbarcaron junto al lugar, tomando los de la villa tan

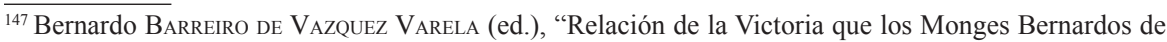
Nuestra Señora de Oya tuvieron de cinco navíos de Turcos, en 20 de Abril" (BNE, ms. 23.555), en Galicia Diplomática, año IV, núm. 16-17, Santiago, 21 y 28 de Abril de 1889, págs. 126-128 y 132-133. Véase también, E. Fernández Villamil, La Escuadra de Galicia, págs. 19-20 y nota 38, y Fray Damián YáñeZ NeIra, "El Monasterio de Santa María de Oya y sus Abades", El Museo de Pontevedra, vol. XXVIII (1974), págs. 145-146, 196-197 y notas 92 y 93. El cartógrafo Pedro Texeira describía así este convento: "Dos leguas [de cabo Silleiro] está una pequeña cala, junto a la qual está un combento de monges bernardos que dizen monasterio de Oya. Tiene en la çerca del convento que cay sobre el portizuelo un terrapleno con dos pieças de artillería de hierro, con que se an defendido de los enemigos piratas munchas bezes aziéndoles retirar, aministrando el manejo de la artillería los mismos monjes". P. TeIXeIRA, "Descripción de España...", fol. 42v., pág. 333.
} 
de sobresalto que apenas pudieron poner en salvo sus personas. Cautivando muchas mugeres, niños y onbres, saqueando la villa se estuvieron como si fuera en Argel dos dias enteros en tierra sin que nadie se atrevera a ofenderles. Estos malos çuceços cauza la poca plática y eyxpiriençia de la guerra ${ }^{148}$.

Para aliviar un poco la penosa situación en que había quedado la población, el arzobispo compostelano concedió licencia a los mareantes de la ría para faenar en días festivos y dedicar su producto a reparar los estragos ${ }^{149}$.

Con el fin de contrarrestar la potencia de los corsarios musulmanes y tratar de proteger las costas gallegas, surgió -además del intento de crear la "Escuadra de Galicia" - un corsarismo gallego apoyado en la Orden General de Corso de 24 de diciembre de 1621, que especificaba que los navíos apresables eran los de turcos y moros, así como también los de los rebeldes de Holanda y Zelanda ${ }^{150}$. Las actividades corsarias contra aquellos eran válidas en todo momento, ya que hacer la guerra a los musulmanes se consideraba natural en la época y no necesitaba ser declarada ${ }^{151}$. Además, a los corsarios musulmanes prisioneros se les daba un trato mucho peor que a los corsarios cristianos: aquellos eran los únicos que podían ser vendidos como esclavos, mientras que a sus oficiales (arraeces, pilotos y contramaestres) se les ahorcaba si habían opuesto resistencia o se les enviaba a galeras en el caso de que se hubieran rendido sin pelear ${ }^{152}$.

En 1634, el capitán Juan Norman, católico inglés al servicio de la Corona española, llegó a Galicia con dos navíos de 120 y 300 toneladas para practicar el corso, pero el más pequeño huyó y el mayor fue hundido poco después por los holandeses cuando volvía de intentar combatir a unos corsarios musulmanes que rondaban por el litoral ${ }^{153}$. En 1638, el Conde de Altamira pretendió armar dos fragatas a remos en Corcubión para defender la costa gallega de corsarios,

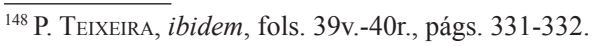

${ }^{149}$ Casto Sampedro y Folgar, Ordenanzas da Confraría do "Corpo Santo" e do Gremio de Mareantes de Pontevedra, A Coruña, Vía Láctea, 1998, pág. 67.

${ }^{150}$ E. Otero Lana, Los corsarios españoles..., págs. 58-59 y 76. Según este autor: El Reino de Galicia no tenía en el siglo XVII una excesiva tradición marinera [mercante], en parte porque las mejoras en la navegación habian disminuido su importancia como punto intermedio en el comercio naval, y en parte por la presencia casi continua de corsarios musulmanes en sus costas. Hay una Real Cédula anterior comunicada al Concejo de Santiago de Compostela en junio de 1615, para que se puedan armar personas por la mar contra piratas. AMS.- Consistorios, sesión del 12 de junio de 1615, fol. 69.

${ }^{151}$ E. OTERo LANA, ibidem, pág. 71, nota 3.

${ }^{152}$ Ibidem, págs. 81 y 248.

${ }^{153}$ Ibidem, pág. 275.
} 
especialmente moros y turcos ${ }^{154}$. Otro armador en corso vasco, Francisco Zárraga Beográn, actuó también en Galicia con una pequeña escuadra. En 1642 solicitó a la Corona que se le permitiese extraer y usar la artillería de un navío turco hundido ocho años antes en sus costas. Poco tiempo después, en su primera salida, el corsario vasco se encontró con ocho navíos gruesos de Argel, que le quemaron y hundieron dos barcos de su escuadra ${ }^{155}$. Otro armador corsario, Juan Cabral Valladares, que era a la vez escribano de la villa de Bouzas, armó tres navíos, enfrentándose a corsarios moros en las isla Cíes ${ }^{156}$.

En cuanto a la "Escuadra de Galicia", creada en 1621 a partir del ofrecimiento hecho por las Juntas del Reino para que éste recuperara el voto en Cortes y defendiera sus costas, no pudo cumplir sus objetivos. Después de las múltiples dificultades que surgieron para su construcción fue utilizada lejos de su territorio y sufrió cuantiosas pérdidas, por lo que se pidió su disolución, pues sólo ocasionaba elevados gastos y sacrificios y no había logrado alterar la situación de inseguridad anterior.

Don Francisco de Caldas, regidor y procurador de la ciudad de Tui, expresaba claramente este sentir en las Juntas del Reino celebradas en 1639:

...atento los muchos tributos con que el reino se alla grabado en los tienpos pressentes, sería más conbiniente para su alibio suplicar a Su Magestad fuesse serbido permitir cessasse la dicha Esquadra, a lo qual se muebe por las raçones siguientes: porque asta oy no se a consiguido el intento para que la dicha Esquadra se ha fabricado, que era para ebadir la obstelidad y inbaçiones que los piratas açen en los puertos de mar deste reino inpidiendo la pesquería hen ellos y cautibando sus naturales y principalmente marineros, cossa que benía a ser a dichos naturales de notable detrimento... ${ }^{157}$.

Con un litoral extenso y poco fortificado y sin contar con la protección de una fuerza naval efectiva, Galicia no tuvo más remedio que seguir soportando las incursiones de los corsarios musulmanes durante todo el siglo XVII. El modus operandi que los caracterizaba incluso llegó a ser un problema añadido a la hora de

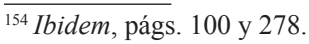

${ }^{155}$ Ibidem, págs. 451-452.

${ }^{156}$ Ibidem, pág. 288.

${ }^{157}$ Sobre la conveniencia de fabricar cuatro nuevos navíos para sustituir a los que fueron capturados por los franceses, 1639, enero, 29.- Coruña. Actas de las Juntas del Reino de Galicia, vol. III, fols. 327v.-328r., Doc. 215-A, págs. 378-379; M. ARTAZA Montero, "Representación política y guerra naval...”, págs. 474477. Sobre las vicisitudes de esta escuadra, véase E. FernÁndez Villamil, La Escuadra de Galicia..
} 
realizar las reclutas para las escuadras de la Corona. Si en circunstancias normales la labor de los agentes comisionados para las levas de marinería ya era difícil por la abierta oposición de los afectados, lo fue todavía más cuando hubo que exigir cuotas de hombres a localidades recientemente saqueadas y/o que tenían parte de sus vecinos cautivos en tierra de infieles o de enemigos.

El incremento de las exigencias militares generaba un descontento creciente en las poblaciones gallegas. Ya en 1616 -un año antes del comienzo de las invasiones de los corsarios berberiscos- la leva de marineros para enviar hombres a la flota de Indias fue una de las disposiciones que mayor oposición encontró en el Reino por entonces; su aplicación provocó un alto grado de incumplimiento y acentuó las reticencias respecto al estamento militar. El regimiento del Concejo coruñés, por ejemplo, trató de oponerse sin éxito a la orden del Capitán General para que la ciudad proporcionara cuatro marineros y dos grumetes, alegando una Real provisión que impedía sacar marinero alguno de ella, por ser frontera y estar los marineros hordinariamente serbiendo en todas las ocasiones que se ofrecieren $^{158}$. Sin embargo, el incumplimiento de esta obligación por parte de un buen número de localidades motivó el envío desde Sevilla de un oficial comisionado por el Consejo de Hacienda, quien debía ejecutar el cobro de las penas impuestas en, algunos lugares del reino de Galicia donde se habian levantado marineros para servir en la flota de Indias por haberse ausentado sin licencia $y$ haber recibido algunas pagas sin servirlas. La coincidencia del desarrollo de esta leva con la irrupción corsaria musulmana complicó aún más el asunto y, finalmente, tuvo que ser el Gobernador el encargado de hacer recaudar el dinero, por las necesidades tan apretadas con que el dicho Reino se hallaba, causadas de la invasión de los turcos ${ }^{159}$.

En 1627, de 2.313 hombres que constaban alistados a la fuerza en el litoral entre Corrubedo y Os Cobres, 95 estaban cautivos. De ellos, una tercera parte (32), lo eran por la villa de Portonovo, localidad que tenía el mayor porcentaje de cautivos entre sus matriculados (el 14'35 \% de 223), cifra muy considerable teniendo en cuenta que en 1631 contaba con 191 vecinos. Seguía en cifras

\footnotetext{
${ }^{158}$ M. C. SaAvedra VÁzquez, Actividad militar..., pág. 344, nota 125, cita AMC, Libros de Actas, sesión de 12 de noviembre de 1616, fol. 403v.

${ }^{159}$ En total se recogieron 59.976 maravedíes desde 1617 a julio de 1618 , y 481.426 maravedíes entre esta última fecha y marzo de 1621, constando como infractores los concejos de Redondela (1 marinero ausente), Bouzas (1 marinero), San Cibrán (1 marinero), Baiona (1 marinero), Santa Marta de Otigueira (1 grumete), Cariño y Vivero (2 marineros), Cillero (1 marinero), Noia (1 marinero), Pontevedra (5 marineros y 2 grumetes), Ribadeo (1 marinero), Camariñas (1 marinero), Muros (4 marineros y grumetes), Malpica (1 grumete), Cangas (1 marinero), Muros y Corcubión (2 grumetes), Carril (1 grumete), Portonovo, Vilanova de Arousa, S. Tomé, Vilagarcía y Rianxo. M. C. SAavedra VÁzQuez, Actividad militar..., ibidem (cita AGS, Contaduría Mayor de Cuentas, 3 época, leg. 807). Véase también, Galicia en el camino de Flandes..., pág. 139 , nota 74 .
} 
absolutas Pontevedra: 19 de un total de 794 inscritos en el registro llamado general; y Cangas y la tierra de Morrazo, con 13 de 573 (no se sabe si de los capturados en 1617). Los 31 cautivos restantes se repartían entre Fefiñáns (5), Pobra do Deán, Vilanova de Arousa, Vilamaior, Sanxenxo y O Grove (4 cada una), y Vilagarcía, Santomé do Mar y Carril (2 cada una). La mayor parte habían sido apresados mientras pescaban o en las travesías de cabotaje ${ }^{160}$.

A finales de 1638, el Consejo de Guerra envió al monarca una solicitud, a petición de los vecinos del Val Miñor y del coto de Saiáns, para que no se efectuasen levas en esas comarcas, pues sus habitantes estaban en permanente estado de alerta y sobre las armas por causa del continuo merodeo de moros, turcos, holandeses y franceses, que no sólo impedían la pesca, sino que hacían, entradas tierra adentro ${ }^{161}$.

En ese año, Baiona fue exceptuada de dar gente para la Marina y el Ejército porque toda era necesaria para la defensa de las playas, acometidas por los, piratas moros y armadas enemigas, desde la guarida habitual que tenían en las islas Cíes. En la villa se organizaron dos compañías de milicias cuya misión era guardar las playas de Panxón, Saiáns y Sanxurxo ${ }^{162}$.

En la segunda mitad del siglo XVII los testimonios que evidencian la inseguridad de la costa siguen siendo abundantes. En Finisterre, los numerosos devotos con que contaba su famoso Cristo invocaban fervorosamente su auxilio ante la incertidumbre y el miedo permanente provocado por las incursiones de los turcos norteafricanos ${ }^{163}$. Ningún lugar junto al mar estaba a salvo. En 1652, el visitador pastoral de la diócesis de Santiago, hallándose en San Vicente de O Grove (arciprestazgo de Salnés), advertía que debido a la excesiva distancia de la iglesia parroquial al pueblo, y para evitar la invasión y profanación de moros, aviendo posibilidad en los feligreses, fuera conveniente mudarla ${ }^{164}$.

La simple mención o sospecha de la presencia de naves musulmanas provocaba en los habitantes de la costa un miedo cerval. Cualquier voz de alarma referida a los moros, aún siendo falsa, se extendía rápidamente, causando la huida desesperada y caótica de una población presa del mayor de los pánicos. Merece la pena reproducir el ilustrativo relato de lo ocurrido en la ya castigada

\footnotetext{
${ }^{160}$ J. M. VÁzQuez Lijó, La Matrícula de Mar..., pág. 68.

${ }^{161}$ M. Artaza Montero, "Representación política y guerra naval...”, pág. 477, nota 120.

${ }^{162}$ J. Santiago y U. Nogueira, Bayona antigua y moderna ..., pág. 162.

${ }^{163}$ Por esos años en torno al ecuador del siglo, el peregrino italiano Domenico Laffi, da testimonio en la crónica de su viaje a Galicia, acerca de la inseguridad marítima provocada por el corsarismo norteafricano, ante el cual, la invocación al Cristo de Finisterre, que contaba con muchos devotos en la Costa da Morte, no pasaba de ser un auxilio espiritual. J. M. VÁzQuEz Lisó, La Matrícula de Mar..., pág. 76, nota 95 (cita a Atanasio López (O.F.M.), Nuevos estudios crítico-históricos acerca de Galicia, vol. II, Madrid, CSIC, Instituto P. Sarmiento de Estudios Gallegos, 1947, pág. 5).

${ }^{164}$ J. M. VÁzQuez Lijó, La Matrícula de Mar..., ibidem.
} 
villa de Portonovo el día de Corpus de 1675, en el transcurso de una misión que celebraban los Jesuitas:

El lunes, después de haber confesado hasta las nueve, me partí a Portonovo acompañado de muchos eclesiásticos y caballeros seglares y del comisario, cura de Portonovo; y aquella tarde pasó el P. Juan con algunos clérigos a los Groves.

Ese día, que fue a diez de Junio, hice la primera plática; y no fue muy grande el concurso, aunque vino la gente de la villa de Sangenjo, que dista de Portonovo como un cuarto de legua; los demás días fue creciendo tanto, que día de Corpus se juntarían alli de cinco a seis mil personas. Acudieron a confesar todos los rectores y curas de la comarca, y algunos mercenarios (sic) que nos venían siguiendo desde Villagarcía. El sermón primero fue junto a la ermita de la villa, que es ayuda de parroquia. Estaba el púlpito en parte que señoreaba el campo que cae al mar, y es como plaza de armas para defensa de los enemigos; pues desde alli les podían cañonear con algunas piezas de artillería.

Por estar aquel sitio descubierto al sol, y cubierto al aire cierzo, mandé que el martes se mudase el púlpito a una calle ancha que está detrás de la puerta colateral de la ermita, por estar aquella calle descubierta del norte, y defendida desde las cinco de la tarde del sol, por hacerle sombra una casa. Aqui el demonio nos hizo una burla muy pesada. Estaba el auditorio muy cumplido, la calle llena y de lo largo de la ermita hacia la calle, todo cubierto de gente. Predicaba el sermón del juicio; y cuando iba a ponderar el último trozo, se levantó una voz baja, de que venían los moros; y cayó de repente tal miedo sobre la gente, que, como la calle donde se predicaba era el camino derecho para huir y escaparse más presto, la gente que estaba en la ermita empezó a abalanzarse a huir. Como la calle era pendiente y cuesta abajo, y estaba tan atestada de gente sentada, y había algunos bancos atravesados; los que de arriba se abalanzaban a huir, no dejaban lugar a los que estaban sentados, y avanzaban por encima de ellos, y muchos tropezaban en los bancos; siendo todo una grita y confusión espantosa.

Yo desde el púlpito daba voces diciendo: "deténganse que no hay nada; miren que es ardid del demonio para inquietarnos "; pero no fue posible detenerlos. Iban cayendo unos sobre otros, dando unos gritos que les reventaban, otros que les quebraban las piernas. Estaban de la parte del púlpito hacia abajo al lado más distante de 
la parte por donde se temía vinieran los moros, muchos hidalgos, y gente principal, y todos se echaron a huir a carrera abierta, con tan grande miedo, que calzados y vestidos se metieron en el río, adonde sube la marea, y se mojaron. Aún hubo caballero, y de muchas obligaciones que siendo casado de pocos años, con una dama muy bizarra, que estaba oyendo el sermón desde una ventana, en compañía de su suegra, y madre de tal caballero, huyó sin acordarse de venir a asistir a su mujer. Huyó el juez, huyó el capitán de la tierra, y aún hubo mozo de obligaciones que fue huyendo media legua, dejando el sombrero y un zapato en el camino, el cual cogió un sacerdote de buen humor y se lo puso; y el otro quedó tan corrido de esta acción, que viendo su sombrero en poder del sacerdote, no se atrevió a decirle palabra.

De toda aquella gente que estaba en lo alto, y con una ojeada pudieran reconocer el campo, no hubo quien tuviera ánimo, sino un muchacho de quince años, hijo del sargento mayor, que cogiendo un chuzo en la mano fue a reconocer lo que habia; y hallando que no parecía ninguno, vino corriendo a dar esta nueva. Duró la turbación cosa de cinco o seis credos. Yo, viendo que la gente se atropellaba, y que corrían peligro de ahogarse, bajaba del púlpito a detenerlos, para que no se atropellasen, y al bajar oyóse la voz que "no había nada”. Aunque el susto duró tan poco, para los que no huyeron; pero para estos duró mucho; porque oyeron la voz falsa de que venían moros, y no pudieron oír la verdadera, pues se habían dado mucha prisa a huir. Un hombre estuvo en peligro de muerte, de una caida que dio con este susto; y a una doncella forastera le lastimaron la cara, pisándola y atropellándola ${ }^{165}$.

En agosto de 1676, y ante una nueva leva, el Concejo de Vigo presentó una queja al Rey en la que refería el mucho sufrimiento de la provincia de Tui, a la que pertenecía la villa, debido a las invasiones portuguesas y a los numerosos desembarcos turcos, que se habían llevado gran cantidad de cautivos ${ }^{166}$. Aún no había pasado un año cuando a principios de julio de 1677 los vigueses volvían a estar otra vez en alerta a causa de los muchos navíos musulmanes que cruzaban ante la costa, destacándose uno de ellos hacia las Cíes para abastecerse de agua, lo que provocó una violenta escaramuza entre los corsarios y los naturales:

\footnotetext{
${ }^{165}$ Elías Reyero González, Misiones del M.R.P. Tirso González de Santalla, XIII prepósito general de la Compañia de Jesús, 1665-1686, Santiago, Tipografía Editorial Compostelana, 1913, págs. 465-466.

${ }^{166}$ María del Carmen González MuÑoz, "Vigo y su comarca en los siglos XVI y XVII", en Vigo en su Historia, Vigo, Caja de Ahorros, 1980, pág. 195.
} 
En estas costas estamos todos con las armas en la mano, por bordear en ellas muchas velas de moros, y por el rezelo de que no executen sus acostumbrados robos. A 5 de este embió la Capitana de Argel un bergantín a hazer aguada en una de las Islas de Bayona, con cerca de 100 hombres de mar y guerra. Lo qual reconocido de los nuestros, se apercibieron algunos barcos longos, con resolucion de apresarle; pero no dio lugar la diligencia a más que adelantarse Don Antonio de Araujo con su chalupa, y 14 hombres de valor, como quién los capitaneava, que desembarcados en la Isla, cogieron a los infieles en la función de aguada, y mataron a 19, recobrándose los demás al bergantín; menos un renegado natural de Canarias, que quedó prisionero, muriendo también dos de los nuestros; el uno hermano de Don Antonio, que por sus muchos bríos causa gran lástima su perdida. Y como reconoce el Señor Marqués de Falces, Conde de Santistevan, Capitán General de este Reyno, originarse en gran parte el arrojo de los bárbaros de la remissión y descuido que ha avido en las guardias y centinelas de estas Marinas, que les han franqueado las frequentes invasiones en ellas, ha dispuesto $\mathrm{Su}$ Excelencia, que se aumenten los cuerpos de guardia y atalayas; $y$ que se observe en ellas la más puntual y vigilante disciplina militar; de suerte, que a la primera señal de que parezcan embarcaciones enemigas, estén prontos en todos los puestos para observarlas, y oponerse a sus intentos, socorriéndose unos a otros con facilidad y brevedad: de cuya acertada disposición se ha començado a ver el fruto en la ocasión referida ${ }^{167}$.

La precariedad defensiva era mayor por la carencia de buques de guerra en el Reino que pudieran proteger su dilatada franja litoral; un problema importante debido al gran número de puertos existentes en el mismo. En consecuencia, la eventual protección de la costa dependía de las posibles recaladas de los navíos Reales, cuya presencia no siempre era garantía suficiente para asegurar su defensa, como ocurrió en septiembre de 1679, cuando el paso por la región de una escuadra de ocho fragatas de moros llevó a temer un posible ataque al convoy encargado de trasladar la infantería española a Flandes ${ }^{168}$.

Las quejas del Reino de Galicia y de las ciudades a título particular a causa de la indefensión que sufría su litoral fueron habituales a lo largo de la centuria; no

\footnotetext{
167 “De Vigo, a 10 de Iulio de 1677”, Gazeta ordinaria de Madrid, núm. 5 (24/07/1677), pág. 16.

${ }^{168}$ María del Carmen SAAVEdRA VÁzQuEZ, "La decadencia militar del imperio español de los Austrias: algunas consideraciones a partir del caso gallego", Semata, vol. 23 (2011), pág. 243, nota 57, cita escrito del Marqués de Villafiel, 1679, septiembre, 24.- Coruña. AGS. Guerra Antigua, leg. 3656.
} 
parecía que hubiesen pasado sesenta años desde las expresadas en la Junta de 1621. En una nueva representación elevada a Carlos II en mayo de 1681, los diputados de las siete ciudades del reino, de forma mancomunada, volvían a lamentar cómo,

En todo el tiempo referido se ha continuado y oi continua por las costas y puertos de la mar que cojen de largo todo este reino la ynbación que hacen los moros y corsarios, apresando los marineros en la mar, saliendo de día y de noche a tierra donde cojen onbres, mugeres y niños los llevan cautibos dejando a otros muertos, siendo más de quinientos los que llevan en cada un año cautibos, para cuio rescate los padres por los hijos, los maridos por sus mugeres, o ellas por sus maridos y los parientes unos por otros, consumen y benden todo quanto tienen, y no llegando salen a pedir de limosna lo que les falta. Y los vecinos y naturales de dichos puertos y costas de la mar acen guarda por tienpo alternando en los parajes más peligrosos a su costa ${ }^{169}$.

La situación era aún más dolorosa y frustrante después del enorme gasto soportado durante muchos años para la fabricación y mantenimiento de la malograda Escuadra de Galicia, compuesta por ocho galeones y un patache, que iba a servir, para linpiar las costas y asistir en ellas después de formada ${ }^{170}$.

\section{LOS CRISTIANOS RENEGADOS: ¿CONVERSOS FINGIDOS O CONVENCIDOS?}

El aumento del número de cristianos cautivos procedentes del área Atlántica a lo largo del siglo XVII, aumentó proporcionalmente el número de ellos que se convirtieron al Islam. Los excesivos malos tratos y trabajos que sufrían los cautivos cristianos, hizo que en muchas ocasiones estos renegaran de su fe con la esperanza de que así serían mejor tratados por sus dueños y acabarían ganando la libertad.

El miedo a no ser nunca rescatados y permanecer toda su vida como esclavos representaba la motivación más común para renegar. Los cautivos de rescate

\footnotetext{
${ }^{169}$ Sobre relación de los servicios prestados, de las contribuciones pagadas por Galicia y de las actuales peticiones del Reino a la Corona, [1681, mayo], Actas de las Juntas del Reino de Galicia, vol. X, fol. 57r.-v. Doc. 131-D, pág. 559. También citan este doc. Lucas Labrada, Descripción económica del Reino de Galicia [1804], Vigo, Editorial Galaxia, 1971, págs. 190-191; y J. M. VÁzQuez Lijó, La Matrícula de Mar..., págs. 76-77. Todavía en 1689, una fragata de turcos capturó algunos barcos en los que varias familias viguesas huían de los rigores de los ministros despachados por el arrendador de la sal para el cobro de deudas en concepto de acopio de este género, 1689, abril, 19.- Coruña, Actas de las Juntas del Reino de Galicia, vol. X, fol. 59r.-v., Doc. 290-D, págs. 786-787.

${ }^{170}$ Actas de las Juntas del Reino de Galicia, ibidem, pág. 559.
} 
podían resistir esperando ser redimidos algún día, pero para aquellos que habían perdido toda esperanza o que nunca la tuvieron, renegar abría las vías y posibilidades para una vida mejor, más leve al menos que la esclavitud. Los cautivos con oficios cualificados y muy valorados, especialmente carpinteros, constructores de navíos, artilleros, etc., aun siendo esclavos, eran respetados, lo que les permitía llevar una vida "normal", pero el resto debían pasar su tiempo de invierno en las duras obras públicas y en verano remando en las galeotas corsarias.

Una vez renegaban, aunque seguían siendo esclavos, en principio obtenían un mejor trato y ganaban privilegios: no llevar cadenas, no ir como galeotes a galeras,... Tras recitar la profesión de fe: La ilaha illa Allah Mohammed resul Allah ("No hay más Dios que Alá y Mahoma es su profeta"), y sufrir la preceptiva circuncisión, el renegado podía acceder a un más amplio abanico de actividades y soñar con ahorrar lo necesario para pagar su libertad o que su dueño acabase liberándolo.

Había otros motivos para renegar, como el deseo de vengarse contra el mal infringido por algún turco, ya que si cometía una agresión siendo cristiano le esperaba la pena de muerte; por una querella de sangre y para evitar el castigo; liberarse de las deudas de otro cristiano; o para poder contraer matrimonio con mujeres musulmanas o renegadas. Este tipo de casamientos proporcionaban la libertad a los cautivos contrayentes y el acceso a la fortuna de sus consortes, de manera que significaba el mejor y más rápido medio para la obtener libertad y la fortuna ${ }^{171}$.

Cuestión aparte eran aquellos que habían renegado siendo niños, de los que en cambio no se dudaba, a pesar de que su conversión se hubiera conseguido en la inmensa mayoría de los casos a la fuerza entre halagos y amenazas. Los niños capturados en edad temprana eran la verdadera fuente de sangre nueva de la sociedad corsaria, en mucha mayor medida que los aventureros que llegaban a Argel en busca de fortuna, o de los renegados que abjuraban después de una época más o menos larga de cautiverio. De su captura provenía el verdadero y más amplio y fiable método de reclutamiento de renegados, no sólo de los del común, sino de los destinados a engrosar las élites turco-berberiscas: arráeces de navío, alcaides y cargos políticos de toda índole de la sociedad corsaria.

Por esta razón, el precio de los niños alcanzaba valores bastante más elevados que el de los adultos, a excepción de las mujeres y de algún personaje principal; eran tan valiosos, que los corsarios raramente accedían a canjearlos. La relativa tolerancia hacia otras religiones que los argelinos mostraban con los adultos, se transformaba en urgencia a la hora de intentar convertir a los menores. Se buscaba

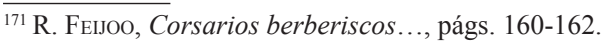


su inmediata conversión para evitar que pudieran ser reclamados por los tratados diplomáticos o rescatados a cambio de dinero; cuanto antes lo consiguieran, más fácil sería convencerlos y asimilarles a la vida del Islam ${ }^{172}$.

También había una ingente cantidad de cristianos, especialmente los procedentes de las capas más desfavorecidas de la sociedad europea, atraídos por los reinos corsarios de Berbería. Argel era la antítesis de la rígida sociedad estamental europea, donde el nacimiento y la familia ordenaban la posición, el prestigio y la carrera de sus habitantes; allí la valía sustituía a la sangre a la hora de prosperar y alcanzar posición. Los hechos y los logros definían el valor de los hombres, y la acción -sobre todo en expediciones de corso- servía de instrumento para trepar por la escala social. La abierta sociedad de la ciudad corsaria acogía a todos aquellos que pudieran contribuir a su riqueza y desarrollo independientemente de su origen y extracción ${ }^{173}$.

Levante, Cataluña, la costa occidental de Portugal y el noroeste Cantábrico, incluyendo Galicia, suministraron un contingente notable de cristianos convertidos al Islam. Las presas en el Atlántico se produjeron sobre todo en el siglo XVII, cuando los corsarios de Salé y Argel se beneficiaban de la colaboración de los marineros del norte. Según Benassar, de 57 renegados apresados en el Estrecho o en el Océano, sólo 5 lo fueron antes de 1610; entre 1611 a 1620 ya eran el doble, aumentando a 26 entre 1621 a 1630 (el periodo más álgido de las correrías berberiscas), y 16 más después de $1630^{174}$.

Para aquellos que se decidían a aceptar plenamente la conversión al Islam, ésta representaba la mejor oportunidad de obtener botín y enriquecerse rápidamente a costa de sus antiguos correligionarios, incluso de aquellos que habían sido sus propios paisanos y vecinos; recuérdese el ataque a la Ría de Vigo. Sin embargo, para muchos renegados navegar en corso suponía también la posibilidad de encontrar la ocasión de volver a la cristiandad.

Muchos renegados deseaban volver a la tierra que les había visto nacer, y no pocas veces lograban escapar. Después debían presentarse ante los tribunales de la Inquisición en busca de la absolución que les librara de ser condenados a galeras por su condición de apostatas convertidos al Islam, y por lo tanto enemigos de la fe cristiana. Se trataba de una muy grave cuestión religiosa, y por esta razón, la mayoría de los renegados, incluso los plenamente convertidos, intentaban acudir al Santo Tribunal cuando eran capturados, con la esperanza de ser liberados si conseguían convencer a los jueces de que eran buenos cristianos y de que su conversión no había sido sincera y sólo obtenida por la fuerza.

\footnotetext{
${ }^{172}$ Ibidem, págs. 172-173.

${ }^{173}$ Ibidem, págs. 153-158. Veáse también B. y L. Benassar, Los cristianos de Alá..., especialmente las págs. 421-448.

${ }^{174}$ B. y L. Benassar, ibidem, págs. 173 y 192-193.
} 
Renegados de origen gallego fueron, por ejemplo, Alonso de Peralta, natural del lugar de Ponte Cordeiro (parroquia de Alxén, municipio de Salvaterra do Miño), de 22 años, quien se presentó ante la Inquisición de Sevilla en 1612; Juan González de Prami?, natural de Santa María de Tioira (Maceda, Ourense), que se convirtió al Islam en 1601 con 18 años y volvió con 28, presentándose ante el Tribunal de la Inquisición de Mar en 1617; Domingo Álvarez (o mozo), natural de Baiona, que tenía 23 años cuando en 1623 se presentó ante el tribunal de la Inquisición de Galicia, sin que conste el año en que se pasó al Islam; Alonso González, de Vilagarcía de Arousa, convertido a los 13 años en 1631, presentándose en 1639, a los 21 años, ante el tribunal de Murcia; Juan Dobarro, natural de Tui, capturado en 1636 y convertido a la edad de 11 años, presentándose ante el tribunal gallego en 1646 cuando volvió con 21 años ${ }^{175}$.

De la misma manera, algunos renegados no gallegos se dirigieron al tribunal de la Inquisición de Galicia para obtener el perdón: Francisco Ximénez, natural de Arjonilla (Jaén), vuelto con 26 años, se presentó ante el tribunal gallego en 1622. Pocos años después, en 1627, se presentaron a él 17 renegados (4 españoles, 9 portugueses, 2 franceses y 2 flamencos), todos ellos evadidos de una nave procedente de Marruecos ${ }^{176}$.

En 1632, otro bajel procedente de Argel, desviado por una tempestad en el Atlántico, pudo evitar el naufragio, pero se vio obligado a atracar en Corcubión. Diez renegados aprovecharon para desaparecer (4 españoles, 4 franceses, 1 inglés y 1 maltés) yendo a presentarse ante la Inquisición en Santiago ${ }^{177}$. Probablemente, algunos de estos proyectos de evasión nacieron y se organizaron partiendo de solidaridades nacionales cimentadas en el exilio (voluntario o no), gracias a una continua relación y a la conservación de la lengua ${ }^{178}$. En 1668 se presentaron también ante la Inquisición de Galicia dos andaluces, Nicolás de Molina, granadino de 38 años, y Juan Román, de 28, natural de Conil (Cádiz) ${ }^{179}$.

Por el contrario - como no podía ser de otro modo- cuando los corsarios musulmanes caían en poder de los cristianos, su destino era, en el mejor de los

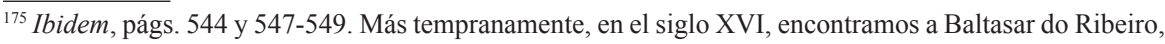
natural de Pontevedra, convertido al Islam con 15 años en 1574, que vuelve en 1580 con 21 y se presenta ante el tribunal de la Inquisición de Sicilia.

${ }^{176}$ Ibidem, págs. 529-530 y 548. Los españoles eran Alonso Benítez, de Jeréz de la Frontera, de 35 años; Alonso Hernández, de Ávila, capturado con 14 años y con 19 en el momento de volver; Diego Martínez, de Alburquerque, de 18 años; Juan Martínez, de Murcia, de 24 años, y Andrés López, de Osuna, de 31.

${ }^{177}$ Ibidem, págs. 523, 529 y 549. Los españoles eran Roque del Campo, de 25 años, originario de Laredo, que fuera capturado en 1621, y convertido con 14 años; Manuel Díaz, de 22 años, procedente de Sanlúcar de Barrameda; y los mallorquines Guillermo Fauvo y Jerónimo del Castillo (este último convertido al Islam en 1623, a los 13 años), ambos también de 22 años.

${ }^{178}$ Ibidem, pág. 530.

${ }^{179}$ Ibidem, pág. 550.
} 
casos, su venta como esclavos y/o remar en galeras. Aunque menos abundantes, también hubo entre ellos casos de conversión al cristianismo ${ }^{180}$. Por razones obvias, la venta de esclavos bautizados a amos de religión musulmana o judía no estaba permitida, prohibición que alcanzaba incluso a los cristianos nuevos. Asimismo, dentro de este comercio de mercancía humana había categorías, y eran preferidos generalmente los esclavos negros, por su mayor docilidad, frente a los berberiscos, más díscolos y con mayor predisposición a fugarse. Los fondos documentales muestran un buen número de ejemplos de compraventa de esclavos negros y musulmanes a lo largo de los siglos XVII y XVIII, producto, en el caso de los segundos, de su creciente presencia en aguas gallegas y de los apresamientos motivados por el fracaso de algunas de sus correrías ${ }^{181}$.

\section{LA DECADENCIA Y EL FIN DEL CORSO BERBERISCO}

A partir del siglo XVIII, las incursiones de los corsarios musulmanes en esta parte del Atlántico fueron decayendo, especialmente tras el paréntesis de debilidad naval española que supuso la Guerra de Sucesión (1700-1714), pero no desaparecieron del todo; bien entrada esta centuria aún persistía el riesgo y se mantenían los turnos de vigilancia en los fachos del litoral.

Veamos un par de ejemplos. El 17 de julio de 1718, el Capitán General de Galicia, Marqués de Risbourcq, escribía desde Coruña al Secretario del Despacho de la Guerra de S.M. informando acerca de navíos de moros que andaban por aquella costa embistiendo a todas las embarcaciones. Una nave holandesa había sostenido un fuerte combate con ellos, por lo que varó, ahogándose once marineros, pudiendo salvarse y huir los demás; se temía que dichos moros saltasen a tierra para tomar cautivos. Una semana después, el 24 de julio, el Capitán General volvía a avisar que los corsarios moros cruzaban el mar desde las islas de Baiona a las Sisargas, por lo que había alarma en el país, ya que como la gente estaba sin armas no podrían impedir cualquier desembarco que intentasen ${ }^{182}$.

\footnotetext{
${ }^{180}$ M. Barrio Gozalo, “Esclavos musulmanes...”, pág. 58.

${ }^{181}$ Sólo por citar algunos ejemplos publicados: en 1631: el alférez Pedro Díaz, sargento mayor de la villa de Pontevedra, compró en pública subasta un esclavo musulmán, cojo de una pierna, que fuera traído a la ría de Pontevedra para su venta después de ser capturado junto con otros de sus correligionarios. En 1649, don Juan Acevedo de Sotomayor, vecino de Bouzas, era dueño de un esclavo moro llamado Alí de Benamar, de 32 años, comprado a una fragata holandesa que lo había apresado en el mar. En 1668, el licenciado don Benito Tavares denunció la fuga de su esclavo, un moro berberisco llamado Benito, de 19 años de edad. En 1671, don Juan Cabral Alemparte, señor del Pazo do Xistro, en Cangas, condujo una partida de 20 moros capturados por los marineros de esta localidad en las Islas Cíes. Fueron llevados a Coruña para ser vendidos en pública subasta. Uno de ellos, de nombre Alí, de 19 años, quedó en Cangas al servicio del clérigo don Gregorio Suárez, mientras que otros dos fueron vendidos en Santiago de camino hacia la ciudad herculina. C. VÁzquez Marinelli et al., Historia de Cangas, págs. 194-197.

182 J. Santiago y Gómez, Historia de Vigo..., págs. 461-462.
} 
El 13 de junio de 1737 se celebró en la iglesia parroquial de A Pobra do Deán un acto fúnebre por un vecino fallecido durante su cautiverio en Argel; fuera apresado el 9 de mayo de 1736 junto con otros 17 vecinos de esta feligresía, que estaban en la altura a las pescadas (merluzas). Después de dos años de cautiverio, por mayo de 1738, diez de ellos habían conseguido regresar tras ser rescatados y liberados ${ }^{183}$.

A partir de la segunda mitad del siglo XVIII la recuperación naval española y algunos éxitos militares provocarían un retroceso del corso berberisco. No obstante, los barcos y las costas de los Estados cristianos aún continuarían sufriendo ataques esporádicos hasta principios del siglo XIX ${ }^{184}$. Tras las guerras napoleónicas, las potencias europeas -cuyo poderío técnico y armamentístico era ya incontestable-suscribieron acuerdos internacionales para proscribir la piratería, lo que llevó a una serie acciones militares contra Argel que culminarían con la ocupación de la capital corsaria por los franceses en 1830.

La intervención de Francia y Gran Bretaña en el Norte de África trajo consigo el establecimiento de protectorados europeos en esta región y la retirada del Imperio Turco del Mediterráneo occidental, anulando definitivamente las bases y las actividades predatorias de los corsarios y piratas berberiscos.

\section{A MODO DE COLOFÓN. UNA REPRESENTACIÓN GALLEGA DE LA BATALLA DE LEPANTO}

Por último, una nota curiosa referida al tema general que nos ocupa, un eco de Lepanto en la Galicia del siglo XVIII: en 1741 la Cofradía del Rosario de Tui erigió en el convento de Santo Domingo de esta ciudad un retablo dedicado a la Virgen del Rosario en el que se representa la batalla de Lepanto, cuya victoria se atribuyó a esta advocación ${ }^{185}$. El retablo muestra a Santo Domingo recibiendo

\footnotetext{
${ }^{183}$ J. M. VÁzQuEz Lijó, La Matrícula de Mar..., pág. 69 y nota 76.

${ }^{184}$ No obstante, a finales del siglo XVIII ya aparecen navíos berberiscos comerciando pacíficamente con los puertos gallegos: en 22 de mayo de 1799, Mohamet Ben Casen, vecino de Larache y capitán del yate Umbirica, parte de Cádiz con un cargamento de sal para el alfolí de Padrón fletado por los responsables de la renta de la sal a través de otro marroquí, Lex Ardemext Burlel, vecino de Tánger, fue interceptado a la altura de las islas Cíes por navíos corsarios ingleses, que lo condujeron a Viana do Castelo. Amparándose en su pabellón neutral pudo continuar el viaje. J. Juega Puig, El estanco de la sal..., pág. 403, cita AHPPo, 287/2, 91. Presenta otros ejemplos de súbditos marroquíes que por los mismos años participan en el tráfico de la sal, Antonio MeIJIDE PARdo, Negociantes catalanes y sus fábricas de salazón en la ría de Arosa (1780-1830), Coruña, Imp. Moret, 1973.

${ }^{185}$ La victoria de la batalla naval de Lepanto fue atribuida a la Virgen del Rosario por haber acontecido el primer domingo de octubre, fecha consagrada a esta advocación por las cofradías del Rosario, fundadas por la Orden de Predicadores, a la que pertenecía el Papa Pío V. Mientras se producía el combate, el Papa organizó un rosario público en la basílica de Santa María la Mayor de Roma y al conocer el triunfo estableció la festividad de la Virgen de las Victorias. En 1573, Gregorio XIII cambió su denominación por el de la Virgen del Rosario y trasladó la fiesta al 7 de octubre.
} 


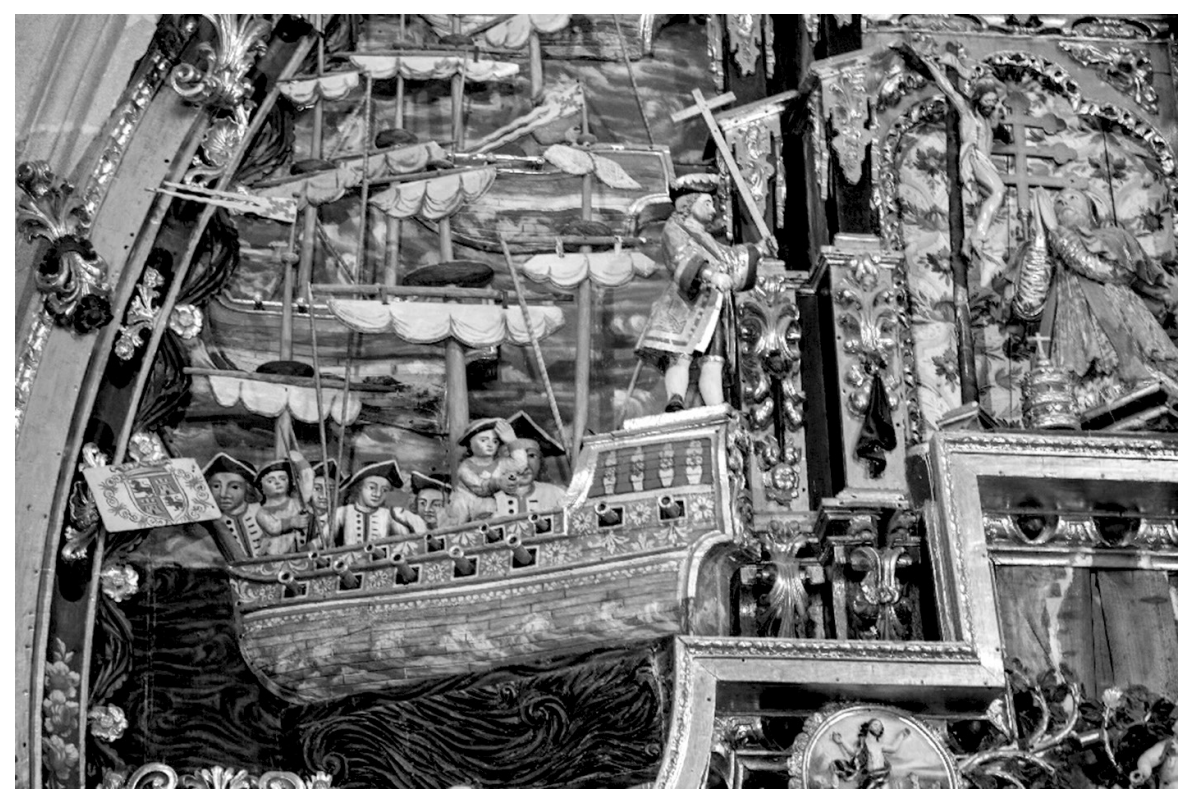

Fig. 5. Detalle del llamado retablo de Lepanto en Santo Domingo de Tui (siglo XVIII).

de las propias manos de la Virgen la invitación al rosario; al Papa San Pío V, que instauró esta festividad; y el mayor ejemplo de las gracias conseguidas, la victoria en la batalla de Lepanto.

La descripción de la parte superior de este retablo es la siguiente:

El ático, que se pliega al marco arquitectónico, adquiere un desarrollo poco usual, en este espacio final de los retablos, pero perfectamente justificado aquí, en su finalidad didáctica. La calle central la ocupan las representaciones de San Pio V y Santo Domingo recibiendo el rosario de la Virgen, enmarcada la primera por arco trilobulado y la segunda por óvalo, ambas flanqueadas por dos pares de estípites muy originales por su diseño. En los extremos se relata la batalla de Lepanto, dejando bien claro quienes son los ganadores y por qué causa ${ }^{186}$.

\footnotetext{
${ }^{186}$ Dolores Álvarez FernÁndez, El retablo barroco en la antigua diócesis de Tui, Pontevedra, Diputación, 2001, págs. 432-435.
} 


\section{BIBLIOGRAFÍA}

Actas de las Juntas del Reino de Galicia, vol. I: 1599-1629, Santiago de Compostela, Consellería de Cultura; Xunta de Galicia, 1995.

Actas de las Juntas del Reino de Galicia, vol. III: 1636-1639, Santiago de Compostela, Consellería de Cultura; Xunta de Galicia, 1997.

Actas de las Juntas del Reino de Galicia, vol. X: 1681-1689, Santiago de Compostela, Consellería de Cultura; Xunta de Galicia, 2002.

Alonso Acero, Beatriz, Orán y Mazalquivir en la política norteafricana de España, 1589-1639, tesis doctoral inédita dirigida por D. José Alcalá-Zamora y Queipo de Llano, Departamento de Historia Moderna, Facultad de Geografía e Historia. Universidad Complutense de Madrid, 1997, vols. I y II.

Alonso Acero, Beatriz, "Entre el Mediterráneo y el Atlántico: corso europeo y corso turco-berberisco en el siglo de los Felipes", en IV Centenario del ataque de Van der Does a las Palmas de Gran Canaria (1999), Coloquio internacional "Canarias y el Atlántico. 1580-1648, Las Palmas de Gran Canaria, Ediciones del Cabildo de Gran Canaria, 2001, págs. 169-185.

Álvarez Fernández, Dolores, El retablo barroco en la antigua diócesis de Tui, Pontevedra, Diputación de Pontevedra, 2001.

Artaza Montero, Manuel, "Representación política y guerra naval en la Galicia de los Austrias", Anuario de Historia del Derecho Español, vol. LXVI (1996), págs. 445-496.

Ávila y La Cueva, Francisco, Historia civil y eclesiástica de la ciudad de Tuy y su Obispado, tomo $1^{\circ}$, Tuy, 1852. (Manuscrito conservado el ACT).

Barreiro de Vázquez Varela, Bernardo, Brujos y Astrólogos de la Inquisición de Galicia y el famoso libro de San Cipriano [1885], Madrid, Editorial Akal/Arealonga, 1973.

Barreiro de Vázquez Varela, Bernardo (ed.), "Información sobre la entrada de los turcos en la villa de Cangas y el daño que hicieron" (Ms. Inédito del Archivo del Excmo. Ayuntamiento de Santiago), Galicia Diplomática: revista semanal de archivos y bibliotecas, historia, arqueología, heráldica, literatura, ciencias y artes, vol. I, núms. 1 (9-VII, págs. 7-8), 2 (16-VII, págs. 12-13), 4 (30-VII, págs. 29-31), 6 (13-VIII, págs. 46-47) y 12 (24-IX, pág. 92), Santiago, 1882.

Barreiro de Vázquez Varela, Bernardo (ed.), "Relación de la Victoria que los Monges Bernardos de Nuestra Señora de Oya tuvieron de cinco navios de Turcos, en 20 de Abril" (ms. 23.555 de la BNE), Galicia Diplomática, núms. 16 (21-IV, págs. 126-128) y 17 (28-IV, 132-133), Santiago, 1889.

Barrio Gozalo, Maximiliano, "Esclavos musulmanes en la España del siglo XVIII", Anales de Historia Antigua, Medieval y Moderna, vol. 49 (2015), págs. 49-59.

Benassar, Bartolomé y Lucile, Los cristianos de Alá. La fascinante aventura de los renegados, Madrid, Editorial Nerea, 1989.

Canoura Quintana, Andrés, A pesca da balea en Galicia nos séculos XVI e XVII, [Santiago], Consellería de Pesca e Asuntos Marítimos; Xunta de Galicia, 2002.

Carro, Jesús, "Entrada de los turcos en la villa de Cangas. Año 1617”, Cuadernos de Estudios Gallegos, vol. V, fasc. XV (1950), págs. 425-428.

Catálogo de la Real Biblioteca, Tomo XIII. Correspondencia del Conde de Gondomar, vols. I, II y III, Madrid, Patrimonio Nacional, 1999-2002. 
Colección de documentos históricos de la Real Academia Gallega, vols. I y II, Coruña, Litografía e Imp. Roel, 1915-1931.

Espinosa Rodríguez, José, Tierra de Fragoso (Notas para la Historia de Vigo y su comarca), Vigo, 1949.

Feijoo, Ramiro, Corsarios berberiscos. El reino corsario que provocó la guerra más larga de la Historia de España, Barcelona, Belacqva de Ediciones y Publicaciones, 2003.

Fernández Duro, Cesáreo, Armada española desde la unión de los Reinos de Castilla y Aragón, vol. III, Madrid, 1900.

Fernández Villamil, Enrique, La Escuadra de Galicia, Pontevedra, El Museo de Pontevedra; CSIC, 1952.

García Tato, Isidro, La casa de Outarelo de Valdeorras. Formación y desarrollo de su patrimonio (siglos XIV-XX), Santiago de Compostela, Gráficas Loureiro, 2001 (Colección Trevinca).

Gazeta ordinaria de Madrid, núm. 5 (24/07/1677), pág. 16.

González López, Emilio, Los políticos gallegos en la Corte de España y la convivencia europea: Galicia en los reinados de Felipe III y Felipe IV, Vigo, Editorial Galaxia, 1969.

González Muñoz, Ma del Carmen, "Vigo y su comarca en los siglos XVI y XVII", en Vigo en su Historia, Vigo, Caja de Ahorros, 1980.

González Muñoz, Ma del Carmen, Galicia en 1571: Población y economía, Sada-Coruña, Ediciós do Castro, 1982.

Gosse, Philip, Historia de la piratería, [Sevilla], Editorial Renacimiento, 2008 (Colección Isla de la Tortuga).

Juega Puig, Juan, El estanco de la sal en Galicia. Siglos XVI-XVII, Madrid, Ministerio de Agricultura, Pesca y Alimentación, 2006.

Labrada, Lucas, Descripción económica del Reino de Galicia [1804], Vigo, Editorial Galaxia, 1971.

Lane-Poole, Stanley, Los corsarios berberiscos, [Sevilla], Editorial Renacimiento, 2011 (Colección Isla de la Tortuga).

Longás, Pedro, "Piratas moros en Galicia (siglo XVII)", Al-Andalus. Revista de las Escuelas de Estudios Árabes de Madrid y Granada, vol. XVI, fasc. 1 (1951), págs. 215-217.

López Ferreiro, Antonio, Historia de la Santa A. M. Iglesia de Santiago de Compostela, vol. IX, Santiago, Seminario Conciliar Central, 1907.

López, Atanasio (O.F.M.), Nuevos estudios crítico-históricos acerca de Galicia, vol. II, Madrid, CSIC; Instituto Padre Sarmiento de Estudios Gallegos, 1947.

Martínez Crespo, José, A Guerra na Galicia do Antigo Réxime (ss. XVI-XIX). Textos e contextos, Noia, Editorial Toxosoutos, 2007 (Colección Anais).

Meijide Pardo, Antonio, Negociantes catalanes y sus fábricas de salazón en la ría de Arosa (1780-1830), Coruña, Imp. Moret, 1973.

Murguía, Manuel, España. Sus monumentos y artes-su naturaleza e historia. Galicia, Barcelona, Establecimiento Tipográfico - Editorial de Daniel Cortizo y C. ${ }^{\text {a }}, 1888$.

Otero Lana, Enrique, Los corsarios españoles durante la decadencia de los Austrias. El corso español del Atlántico peninsular en el siglo XVII (1621-1697), Madrid, Ministerio de Defensa, 1999. 
Pérez Herrero, Enrique (coord.), Documentos y estudio sobre el corsarismo en Canarias (Descripción archivistica, transcripción y edición facsímil), Las Palmas de Gran Canaria, Gobierno de Canarias - Beginbook Ediciones, 2011.

Reyeros, P. Elías (S.J.), Misiones del M.R.P. Tirso González de Santalla XIII prepósito general de la Compañía de Jesús, 1665-1686, Santiago, Tipografía Editorial Compostelana, 1913.

Rodal González, Manuel, "Afán de la justicia seglar por mostrar brujas en la villa de Cangas". Pontevedra. Revista de Estudios Provinciais, vols. 8-9 (1992), págs. 197-230.

Saavedra Vázquez, María del Carmen, Actividad militar, economía y sociedad en la España noratlántica, 1556-1648, tesis doctoral, Universidad de Santiago, 1992.

Saavedra Vázquez, María del Carmen, Galicia en el camino de Flandes: actividad militar, economía y sociedad en la España noratlántica, 1556-1648, Sada, A Coruña, Ediciós do Castro, 1996.

Saavedra Vázquez, María del Carmen, "La decadencia militar del imperio español de los Austrias: algunas consideraciones a partir del caso gallego", Semata, vol. 23 (2011), págs. 229-251.

Sampedro y Folgar, Casto, Ordenanzas da Confraría do "Corpo Santo" e do Gremio de Mareantes de Pontevedra, A Coruña, Vía Láctea, 1998.

Santiago y Gómez, José, Historia de Vigo y su comarca, Madrid, Imprenta y litografía del Asilo de Huérfanos, 1896.

Santiago, José y Nogueira, Ulpiano, Bayona antigua y moderna, Madrid, Imprenta del Asilo de Huérfanos del Sagrado Corazón de Jesús, 1902.

Taboada y Leal, Nicolás, Descripción topográfico-histórica de la ciudad de Vigo, su ría y alrededores, Santiago, Imp. de la Viuda e Hijos de Compañel, 1840.

Teixeira, Pedro, "Descripción de España y de las costas y puertos de sus reinos", fols. 35r.-v., en Felipe Pereda y Fernando Marías (eds.), El Atlas del Rey Planeta (1634), Hondarribia, Editorial Nerea, 2002.

Vázquez Lijó, José Manuel, La Matrícula de Mar y sus repercusiones en la Galicia del siglo XVIII, tesis doctoral inédita, Universidad de Santiago, 2005.

Vázquez Marinelli, Carlos; Moreira Pumar, José; Rodal González, Manuel, Historia de Cangas, Pontevedra, Diputación Provincial de Pontevedra, Servicio de Publicaciones, 2007.

Yáñez Neira, Fray Damián, “El Monasterio de Santa María de Oya y sus Abades”, El Museo de Pontevedra, vol. XXVIII (1974), págs. 145-227. 